Cochrane Database of Systematic Reviews

\title{
Pharmaceutical interventions for emotionalism after stroke
}

\section{(Review)}

Allida S, Patel K, House A, Hackett ML

Allida S, Patel K, House A, Hackett ML.

Pharmaceutical interventions for emotionalism after stroke.

Cochrane Database of Systematic Reviews 2019, Issue 3. Art. No.: CD003690.

DOI: 10.1002/14651858.CD003690.pub4.

www.cochranelibrary.com 
TABLE OF CONTENTS

HEADER 1

ABSTRACT

PLAIN LANGUAGE SUMMARY ....

SUMMARY OF FINDINGS

BACKGROUND

OBJECTIVES

METHODS

RESULTS

Figure 1.

Figure 2.

Figure 3.

DISCUSSION

AUTHORS' CONCLUSIONS

ACKNOWLEDGEMENTS

REFERENCES

CHARACTERISTICS OF STUDIES

DATA AND ANALYSES

Analysis 1.1. Comparison 1 Pharmaceutical interventions versus placebo, Outcome 1 Emotionalism.

Analysis 1.2. Comparison 1 Pharmaceutical interventions versus placebo, Outcome 2 Emotionalism: mean scores at end of treatment.

Analysis 1.3. Comparison 1 Pharmaceutical interventions versus placebo, Outcome 3 Depression: 1. Mean scores at end of treatment.

Analysis 1.4. Comparison 1 Pharmaceutical interventions versus placebo, Outcome 4 Depression: 2. Average change in scores between baseline and end of treatment.

Analysis 1.5. Comparison 1 Pharmaceutical interventions versus placebo, Outcome 5 Cognitive functioning: mean scores at end of treatment.

Analysis 1.6. Comparison 1 Pharmaceutical interventions versus placebo, Outcome 6 Activities of daily living: 1. Mean scores at end of treatment.

Analysis 1.7. Comparison 1 Pharmaceutical interventions versus placebo, Outcome 7 Adverse events: 1. Death. .....................

Analysis 1.8. Comparison 1 Pharmaceutical interventions versus placebo, Outcome 8 Adverse events: 2. All. ..........................

Analysis 1.9. Comparison 1 Pharmaceutical interventions versus placebo, Outcome 9 Adverse events: 3 . Leaving the study early (including death).

ADDITIONAL TABLES

APPENDICES

WHAT'S NEW

HISTORY

CONTRIBUTIONS OF AUTHORS

DECLARATIONS OF INTEREST

SOURCES OF SUPPORT

DIFFERENCES BETWEEN PROTOCOL AND REVIEW

INDEX TERMS 
[Intervention Review]

\section{Pharmaceutical interventions for emotionalism after stroke}

Sabine Allida ${ }^{1}$, Kulsum Patel ${ }^{2}$, Allan House ${ }^{3}$, Maree L Hackett ${ }^{4}$

1Faculty of Health, University of Technology Sydney, Sydney, Australia. ${ }^{2}$ Clinical Practice Research Unit, School of Health, University of Central Lancashire, Preston, UK. ${ }^{3}$ Division of Psychological and Social Medicine, Leeds Institute of Health Sciences, University of Leeds, Leeds, UK. ${ }^{4}$ School of Public Health, The University of Sydney, Sydney, Australia

Contact address: Maree L Hackett, School of Public Health, The University of Sydney, Sydney, NSW, 2050, Australia. mhackett@georgeinstitute.org.au.

Editorial group: Cochrane Stroke Group.

Publication status and date: New search for studies and content updated (no change to conclusions), published in Issue 3, 2019.

Citation: Allida S, Patel K, House A, Hackett ML. Pharmaceutical interventions for emotionalism after stroke. Cochrane Database of Systematic Reviews 2019, Issue 3. Art. No.: CD003690. DOI: 10.1002/14651858.CD003690.pub4.

Copyright @ 2019 The Cochrane Collaboration. Published by John Wiley \& Sons, Ltd.

\section{A B S T R A C T}

\section{Background}

Antidepressants may be useful in the treatment of abnormal crying associated with stroke. This is an update of a Cochrane Review first published in 2004 and last updated in 2010.

\section{Objectives}

To determine whether pharmaceutical treatment reduces the frequency of emotional displays in people with emotionalism after stroke.

\section{Search methods}

We searched the trial register of Cochrane Stroke (last searched May 2018). In addition, we searched the Cochrane Central Register of Controlled Trials (CENTRAL; to May 2018), MEDLINE (1966 to 14 May 2018), Embase (1980 to 14 May 2018), CINAHL (1982 to 14 May 2018), PsycINFO (1967 to 14 May 2018), BIOSIS Previews (2002 to 14 May 2018), Web of Science (2002 to 14 May 2018), WHO ICTRP (to 14 May 2018), ClinicalTrials.gov (to 14 May 2018), and ProQuest Dissertations and Theses Database (to 14 May 2018).

\section{Selection criteria}

Randomised controlled trials (RCTs) and quasi-RCTs comparing psychotropic medication to placebo in people with stroke and emotionalism (also known as emotional lability, pathological crying or laughing, emotional incontinence, involuntary emotional expression disorder, and pseudobulbar affect).

\section{Data collection and analysis}

Two review authors independently selected studies, assessed risk of bias, extracted data from all included studies, and used GRADE to assess the quality of the body of evidence. We calculated mean difference (MD) or standardised mean difference (SMD) for continuous data and risk ratio (RR) for dichotomous data with 95\% confidence intervals (Cls). We assessed heterogeneity using the $\mathrm{I}^{2}$ statistic. The primary emotionalism measures were the proportion of participants achieving at least a $50 \%$ reduction in abnormal emotional behaviour at the end of treatment, improved score on Center for Neurologic Study - Lability Scale (CNS-LS), Clinician Interview-Based Impression of Change (CIBIC) or diminished tearfulness.

\section{Main results}

We included seven trials with a total of 239 participants. Two trials were of cross-over design, and outcome data were not available from the first phase (precross-over) in an appropriate format for inclusion as a parallel randomised controlled trial (RCT). Thus, the results of the review are based on five trials with 213 participants. Treatment effects were observed on the following primary endpoints of emotionalism: 
There is very low quality of evidence from one small RCT that antidepressants increased the number of people who had $50 \%$ reduction in emotionalism (RR $16.50,95 \% \mathrm{Cl} 1.07$ to $253.40 ; 19$ participants) and low quality evidence from one RCT of improved scores on Center for Neurologic Study - Lability Scale (CNS-LS) and Clinician Interview-Based Impression of Change (CIBIC) with antidepressants (RR 1.44, 95\% $\mathrm{Cl} 0.95$ to $2.19 ; 28$ participants). There was moderate quality evidence from three RCTS that they increased the number of people who had a reduction in tearfulness ( $\mathrm{RR} 2.18,95 \% \mathrm{Cl} 1.29$ to 3.71; 164 participants); and low quality evidence from one RCT of improved scores on the Pathological Laughter and Crying Scale (PLCS) (MD 8.40, 95\% Cl 11.56 to 5.24; 28 participants).

Six trials reported adverse events (death) and found no difference between the groups in death (RR 0.59, $95 \%$ Cl 0.08 to $4.50 ; 6$ RCTs, 172 participants, moderate-quality evidence).

\section{Authors' conclusions}

Antidepressants may reduce the frequency and severity of crying or laughing episodes based on very low quality evidence. Our conclusions must be qualified by several methodological deficiencies in the studies and interpreted with caution despite the effect being very large. The effect does not seem specific to one drug or class of drugs. More reliable data are required before appropriate conclusions can be made about the treatment of post-stroke emotionalism. Future trialists investigating the effect of antidepressants in people with emotionalism after stroke should consider developing and using a standardised method to diagnose emotionalism, determine severity and assess change over time; provide treatment for a sufficient duration and follow-up to better assess rates of relapse or maintenance and include careful assessment and complete reporting of adverse events.

\section{PLAIN LANGUAGE SUMMARY}

\section{Pharmaceutical interventions for emotionalism after stroke}

\section{Review question}

Does pharmaceutical treatment reduce the frequency of unwanted emotional displays in people with emotionalism after stroke compared to placebo?

\section{Background}

Emotionalism often occurs after stroke. Emotionalism means that the person has difficulty controlling their emotional behaviour. People after stroke may suddenly start crying or, less commonly, laughing for no apparent reason. This is distressing for that particular person and their carers. Antidepressants, known to be helpful in people with depression, may be an effective treatment for emotionalism after stroke, but there have been very few randomised controlled trials in this area.

\section{Search date}

We identified studies by searches conducted on 14 May 2018.

\section{Study characteristics}

We included seven randomised controlled trials involving 239 participants in the review, which reported on the use of antidepressants for treating emotionalism. Trials ranged from small (10 participants) to large (92 participants). Mean/median age of participants ranged from 57.8 years to 73 years. Studies were from Europe (UK: 1, Denmark: 1, Scotland: 1, and Sweden: 1); Asia (South Korea: 1; and Japan: 1); and the USA: 1.

\section{Key results}

We included seven trials involving 239 participants (we identified no new trials since the previous version of the review). Two trials were of cross-over design, and outcome data were not available from the first phase (precross-over) in an appropriate format for inclusion as a parallel randomised controlled trial (RCT). Data were only available for five trials with 213 participants. We observed treatment effects on the following: $50 \%$ reduction in emotionalism, improvements (reduction) in lability, Clinician Interview-Based Impression of Change (CIBIC), diminished tearfulness and scores on the Pathological Laughter and Crying Scale (PLCS). However, confidence intervals were wide indicating that treatment may have had only a small positive effect, or even a small negative effect (in one trial). Six trials reported death as an adverse event and found no differences between groups.

\section{Quality of the evidence}

We rated the evidence from very low to moderate quality due to these being small trials with some degree of bias.

\section{Conclusion}

Antidepressant drugs appear to reduce outbursts of crying or laughing. More trials with systematic assessment and reporting of adverse events are needed to ensure that these benefits outweigh the risks. 
SUMMARY OF FINDINGS

Summary of findings for the main comparison. Pharmaceutical interventions compared to placebo for emotionalism after stroke

Pharmaceutical interventions compared to placebo for emotionalism after stroke

Patient or population: emotionalism after stroke

Setting: inpatient

Intervention: pharmaceutical interventions

Comparison: placebo

\begin{tabular}{|c|c|c|c|c|c|c|}
\hline \multirow[t]{2}{*}{ Outcomes } & \multicolumn{2}{|c|}{ Anticipated absolute effects ${ }^{\star}(95 \% \mathrm{Cl})$} & \multirow{2}{*}{$\begin{array}{l}\text { Relative effect } \\
(95 \% \mathrm{Cl})\end{array}$} & \multirow{2}{*}{$\begin{array}{l}\text { № of partici- } \\
\text { pants } \\
\text { (studies) }\end{array}$} & \multirow{2}{*}{$\begin{array}{l}\text { Certainty of } \\
\text { the evidence } \\
\text { (GRADE) }\end{array}$} & \multirow[t]{2}{*}{ Comments } \\
\hline & Risk with placebo & $\begin{array}{l}\text { Risk with pharmaceutical in- } \\
\text { terventions }\end{array}$ & & & & \\
\hline $\begin{array}{l}\text { Emotionalism: } 50 \% \text { reduction in } \\
\text { emotionalism }\end{array}$ & 0 per 1000 & $\begin{array}{l}777 \text { per } 1000 \\
(7 \text { to } 9)\end{array}$ & $\begin{array}{l}\text { RR } 16.50 \\
\text { (1.07 to } 253.40)\end{array}$ & $\begin{array}{l}19 \\
(1 \mathrm{RCT})\end{array}$ & $\begin{array}{l}\oplus \ominus \ominus \ominus \\
\text { Very lowa, b }\end{array}$ & \\
\hline $\begin{array}{l}\text { Emotionalism: improved score on } \\
\text { Center for Neurologic Study - Lability } \\
\text { Scale (CNS-LS) }\end{array}$ & 643 per 1000 & $\begin{array}{l}926 \text { per } 1000 \\
(611 \text { to } 1000)\end{array}$ & $\begin{array}{l}\text { RR } 1.44 \\
\text { (0.95 to } 2.19)\end{array}$ & $\begin{array}{l}28 \\
(1 \mathrm{RCT})\end{array}$ & $\begin{array}{l}\oplus \oplus \ominus \ominus \\
\text { Low }^{a}\end{array}$ & \\
\hline $\begin{array}{l}\text { Emotionalism: clinician inter- } \\
\text { view-based impression of change - } \\
\text { improved score }\end{array}$ & 643 per 1000 & $\begin{array}{l}926 \text { per } 1000 \\
(611 \text { to } 1000)\end{array}$ & $\begin{array}{l}\text { RR } 1.44 \\
\text { (0.95 to } 2.19)\end{array}$ & $\begin{array}{l}28 \\
(1 \mathrm{RCT})\end{array}$ & $\begin{array}{l}\oplus \oplus \ominus \ominus \\
\text { Low }^{a}\end{array}$ & \\
\hline $\begin{array}{l}\text { Emotionalism: diminished tearful- } \\
\text { ness }\end{array}$ & 292 per 1000 & $\begin{array}{l}636 \text { per } 1000 \\
(425 \text { to } 1000)\end{array}$ & $\begin{array}{l}\text { RR } 2.18 \\
\text { (1.29 to } 3.71)\end{array}$ & $\begin{array}{l}164 \\
\text { (3 RCTs) }\end{array}$ & $\begin{array}{l}\oplus \oplus \ominus \ominus \\
\text { Moderatec }\end{array}$ & \\
\hline $\begin{array}{l}\text { Adverse events: } 1 \text {. death: at end of } \\
\text { treatment }\end{array}$ & 0 per 1000 & $\begin{array}{l}0 \text { per } 1000 \\
(2 \text { to } 92)\end{array}$ & $\begin{array}{l}\text { RR } 0.59 \\
\text { (0.08 to } 4.50)\end{array}$ & $\begin{array}{l}172 \\
\text { (6 RCTs) }\end{array}$ & $\begin{array}{l}\oplus \oplus \oplus \ominus \\
\text { Moderateb }\end{array}$ & \\
\hline
\end{tabular}

${ }^{\star}$ The risk in the intervention group (and its 95\% confidence interval) is based on the assumed risk in the comparison group and the relative effect of the intervention (and its $95 \% \mathrm{Cl})$.

Cl: confidence interval; MD: mean difference; OR: odds ratio; $\mathbf{R C T}$ : randomised controlled trial; RR: risk ratio

\section{GRADE Working Group grades of evidence}

High certainty: we are very confident that the true effect lies close to that of the estimate of the effect 
Moderate certainty: we are moderately confident in the effect estimate; the true effect is likely to be close to the estimate of the effect, but there is a possibility that it is substantially different

Low certainty: our confidence in the effect estimate is limited; the true effect may be substantially different from the estimate of the effect

Very low certainty: we have very little confidence in the effect estimate; the true effect is likely to be substantially different from the estimate of effect

a We downgraded the quality of evidence as $<50$ participants in total and only 1 study contributed to the analysis.

bWe downgraded the quality of evidence due to imprecision.

cWe downgraded the quality of evidence as we rated one of the studies at high risk for attrition bias. 


\section{B A C K G R O U N D}

\section{Description of the condition}

Disturbances of emotional behaviour, such as difficulty controlling crying or laughing, are common after stroke (House 1989). Poeck 1969 distinguished two main types of disturbed emotionality associated with brain lesions: one he called pathological crying and laughing, and the other emotional lability. The main differences were that in the former, provocation was by non-emotive or incongruous stimuli and the emotional display was socially abnormal and unstable, while in the latter, emotional behaviour was more socially familiar and provoked by typically emotive stimuli. The terminology is used inconsistently in the literature (Allman 1989), and the evidence to support Poeck's dichotomy is not strong. In order to avoid prejudging the issue we have preferred a general term for all such disorders of emotionality and have called the problem 'emotionalism' - the habit of weakly yielding to emotion (House 1989). The essential feature of emotionalism is an increase in emotional behaviour - usually crying, but sometimes laughing - that the patient reports as being outside normal control, so that he or she cries or laughs in situations that would not previously have provoked such behaviour. Onset of episodes is often reported as being more sudden and unpredictable than usual but, even so, the majority of sufferers report precipitants, which usually, but not always, are congruent with their emotional response.

There are other disturbances of emotional behaviour after stroke, especially irritable or anxious behaviours. By convention, however, they are not included in the present category, which is restricted to crying and laughing. Emotionalism is associated with an increase in depressive symptoms. Nonetheless, most people with emotionalism do not have a diagnosable depressive disorder and many do not have significant depressive symptoms at all (Calvert 1998; Kim 2000).

The reported prevalence of emotionalism varies across studies. Results of one systematic review, which included 15 English language studies involving 3391 participants, indicated that emotionalism affects about $17 \%$ of survivors in the first month, $20 \%$ between one and six months, and $12 \%$ more than six months after stroke (Gillespie 2016). It tends to decline in frequency and severity over the first year, and a few have persistent severe problems. People with emotionalism describe distress and embarrassment, and thereby social avoidance and impaired quality of contact with friends and family.

\section{Description of the intervention}

Until recently, there had been no Food and Drug Administration (FDA)-approved drug to treat emotionalism. However, there are several classes of drugs consistently used by clinicians in an offlabel manner. These drugs are mainly used to treat various central nervous system conditions, targeting serotonin, monoamine, or dopamine receptors. There are case reports and case series suggesting that disorders of emotionality (variously named and defined) may respond to mirtazepine (Kim 2005), imipramine (Allman 1992a), amitriptyline (Schiffer 1983), doxepin (Schiffer 1983), nomifensine (Sandyk 1985), fluoxetine (Hanger 1993; Nahas 1998; Panzer 1992; Sloan 1992), sertraline (Benedek 1995; Mukand 1996; Muller 1999; Nahas 1998; Tan 1996), paroxetine (Muller 1999), and also to lithium (Massey 1981), L-dopa (Udaka 1984; Wolf 1997), and venlafaxine (Smith 2003)

\section{How the intervention might work}

Classic tricyclic antidepressants commonly used to treat emotionalism have actions as alpha-1-adrenoreceptor antagonists, histamine $\mathrm{H}_{1}$ receptor antagonists, noradrenaline reuptake inhibitors and $5 \mathrm{HT}$ reuptake inhibitors with varying affinities while the mechanism of action of selective serotonin reuptake inhibitors (SSRIs) is through blocking the reuptake of serotonin at neural synapses by selectively inhibiting the 5HT transporter. For other antidepressants such as mirtazepine, L-dopa works as a non-competitive inhibitor of the N-methyl-D-aspartate glutamate receptor. However, the effect of these drugs on the disorder of emotionality remain unclear. It does not appear to be the result of a simple antidepressant action, although amelioration of coexisting depression, which is exacerbating the emotionalism, may be the mechanism of action for some. Recovery occurs in people without a depressive disorder; at times, it occurs in a dramatic fashion, within 24 to 48 hours of starting a low dose, and abnormal laughter may also respond to treatment (Lauterbach 1991; Schiffer 1983). There are case reports suggesting that withdrawal of antidepressants leads to re-emergence of emotionalism, while reinstatement leads to resolution (Schiffer 1983; Seliger 1989). However, drug treatment is not always effective and may be complicated by common unacceptable side effects. We have been able to find two case reports of psychological therapy (Brookshire 1970; Sacco 2008).

\section{Why it is important to do this review}

Emotionalism is an under-recognised and under-treated condition that adversely affects individuals poststroke worldwide. Treatment options include the off-label use of a range of antidepressants. However, there are uncertainties surrounding the benefits over the risks associated with their use. We undertook a systematic review of all randomised controlled trials (RCTs) and quasi-RCTs (published) of pharmaceutical agents for the treatment of emotionalism associated with stroke. We did not find any RCTs evaluating nondrug (psychological) interventions; we will consider any future trials in this area in a separate review.

\section{OB JECTIVES}

The primary objective was to determine whether pharmaceutical treatment reduces the frequency of emotionalism or emotional displays after stroke.

The secondary objectives were to determine whether treatment improves social functioning or health-related quality of life after stroke or their principal caregivers. We also aimed to determine the safety, adherence to, and acceptance of treatment.

\section{METHODS}

\section{Criteria for considering studies for this review}

\section{Types of studies}

We considered all relevant randomised controlled trials (RCTs) in people with a clinical diagnosis of stroke, where a pharmaceutical agent used specifically for the treatment of emotionalism was compared with placebo. We excluded trials in which the allocation to treatment or placebo was not random. We excluded trials that 
compared two or more antidepressant drugs, but which did not include a placebo group. We identified RCTs and cross-over trials in all languages. There was no restriction on eligibility of RCTs on the basis of sample size, duration of follow-up, or publication status.

When we found studies meeting all the criteria for inclusion, but not presenting any outcome data (and such data were not available from the authors) and could therefore not contribute to any pooled estimate of effect, we regarded these studies as 'dropouts' rather than ineligible, and they are listed in Table 1 to indicate that they have not been overlooked.

\section{Types of participants}

All participants had to have established emotionalism at entry into the trial. The essential feature of emotionalism is an increase in emotional behaviour - usually crying, but sometimes laughing that the patient reports as being outside normal control, so that he or she cries or laughs in situations that would not previously have provoked such behaviour. Onset of episodes is often reported as being more sudden and unpredictable than usual, but even so most people report precipitants, which usually are congruent with their emotional response.

We included all participants with a confirmed history of stroke, at any stage after onset, where there was an explicit intention to provide a pharmacological agent to treat emotionalism associated with stroke. Stroke was defined according to standard clinical criteria. The criteria include cerebral infarction, intracerebral haemorrhage and uncertain pathological subtypes, but exclude subarachnoid haemorrhage, which has a different natural history and management strategy to other stroke subtypes. There were no restrictions on the basis of age, sex, or other characteristics. We excluded trials that included mixed populations (such as stroke and head injury or other central nervous system disorders) unless separate results for those with stroke could be identified. We included people with a diagnosed mood disorder or a mood score above the standard cut-off scores at baseline, provided it was clear that they also met criteria for emotionalism. We excluded those who were being treated primarily for a strokeassociated pain syndrome or for stroke-associated depression, even if emotionalism was measured as a secondary (post hoc) outcome.

\section{Types of interventions}

We included any trial that attempted to evaluate a comparison between a pharmacological agent and placebo for the treatment of emotionalism following stroke. Specific pharmacological agents considered included tricyclic antidepressants (e.g. nortriptyline, imipramine, and clomipramine), selective serotonin reuptake inhibitors (SSRIs) (e.g. fluvoxamine, fluoxetine, citalopram, sertraline, citraline and paroxetine), monoamine oxidase inhibitors (MAOIs) (e.g. moclobemide), and other antidepressant medications. We found no trials of psychostimulants (e.g. methylphenidate), mood stabilisers (e.g. lithium), benzodiazepines, or combined preparations. We will include any future trials but will analyse them separately.

\section{Types of outcome measures}

\section{Primary outcomes}

Emotionalism: despite widespread acknowledgement of the importance of the problem, there is no widely accepted standardised set of diagnostic criteria for emotionalism. Therefore, we planned the primary emotionalism endpoint to be the proportion of participants who, at the end of treatment, met the criteria for emotionalism that were applied by the study authors in recruiting to the trial. However, data for this endpoint were not available. In the current review, the primary emotionalism measures were as follows.

- The proportion of participants achieving at least a 50\% reduction in abnormal emotional behaviour at the end of treatment.

- Improved score on Center for Neurologic Study - Lability Scale (CNS-LS).

- Clinician Interview-Based Impression of Change (CIBIC).

- Diminished tearfulness.

\section{Secondary outcomes}

- Emotionalism: mean scores at end of treatment. There are a number of measures reported in the published literature (Allman 1992b; Moore 1997; Newsom-Davis 1999; Robinson 1993a), but apart from frequency of emotional behaviour, there is no widely accepted standardised measure of severity of emotionalism that could be used to measure outcome as a continuous variable.

- Depression: mean scores at end of treatment.

- Depression: average change in scores between baseline and end of treatment. Depression, as measured on scales, such as the Hamilton Depression Rating Scale (HDRS) (Hamilton 1960), Montgomery Åsberg Depression Rating Scale (MADRS) (Montgomery 1979), Geriatric Depression Scale (GDS) (Gompertz 1993), Beck Depression Inventory (BDI) (Beck 1961), and Hospital Anxiety and Depression Scale (Depression subscale, HADS-D) (Zigmond 1983), or as measured on composite scales, such as the General Health Questionnaire (GHQ) (Goldberg 1972).

- Cognitive functioning: mean scores at end of treatment. Cognition as measured on scales such as the Mini-Mental State Examination (MMSE) (Folstein 1975).

- Activities of daily living: mean scores at end of treatment. Activities of daily living as measured on scales such as the Barthel Index (BI) (Mahoney 1965).

- Disadvantages of treatment were recorded as:

* adverse events: death

* adverse events: all

* adverse events: leaving the study early (including death).

- We identified additional endpoints for use in further reviews, where measured.

* Proportion who no longer meet the trial authors' criteria for emotionalism.

* Proportion who scored above accepted cut-offs for identifying mood disorders, using mood rating scales.

* Proportion who met the standard psychiatric diagnostic criteria for major depression or dysthymia (Diagnostic and 
Statistical Manual of Mental Disorders (DSM): DSM-IIIR, DSMIV) (APA 1987; APA 1994).

* Mean change in handicap from baseline to follow-up, as measured on scales, such as the Modified Rankin Scale (mRS) (van Swieten 1998).

* Mean change in health-related quality of life from baseline to follow-up, as measured on scales such as the 36-item Short Form questionnaire (SF-36) (Ware 1993), or the Nottingham Health Profile (NHP) (Hunt 1986).

\section{Search methods for identification of studies}

This review is an update of a previously published Cochrane Review (Hackett 2010). The first published review was in 2004 (House 2004; Appendix 1). For this update, we searched all databases from 2008 until May 2018.

\section{Specialised Register of Cochrane Stroke}

Cochrane Stroke's Information Specialist searched the Specialised Register of Cochrane Stroke on 14 May 2018.

\section{Electronic searches}

We searched the following databases on 14 May 2018.

- Cochrane Central Register of Controlled trials (CENTRAL): Issue 4, 2018, the Cochrane Library (Appendix 2).

- MEDLINE (OVID): 1966 to May 2018 (Appendix 3).

- Embase (OVID): 1980 to May 2018 (Appendix 4).

- CINAHL (EBSCO): 1982 to May 2018 (Appendix 5).

- PsycINFO (OVID): 1967 to May 2018 (Appendix 6).

- BIOSIS Previews (Web of Science): January 2002 to May 2018 (Appendix 7).

- Web of Science (ISI): January 2002 to May 2018 (Appendix 8).

\section{Searching other resources}

We also searched the following resources using ("emotion" or "laughing" or "tearful" or "pseudobulbar affect" and "stroke" or "cerebral hemorrhage" or "brain ischemia" from inception to May 2018.

- ClinicalTrials.gov (clinicaltrials.gov).

- World Health Organization International Clinical Trials Registry Platform (WHO ICTRP) (who.int/ictrp/en/).

- ProQuest Dissertations and Theses Database.

We also searched abstracts and conference proceedings from the following international conferences for relevant studies.

- European Stroke Conference (2011 to 2018).

- Stroke Society of Australasia Annual Scientific Meetings (2011 to 2017).

- World Stroke Congress (2000 to 2016).

- Asia Pacific Stroke Conference (2011 to 2017).

The full search strategies for other resources are in Appendix 9.

\section{Personal communication}

We contacted the study authors for information on ongoing studies or to request additional study data.

\section{Reference lists}

We searched the reference lists of relevant trials, systematic reviews and reviewed chapters in books on the prevention and treatment of depression and management of stroke, including but not limited to, reviews of the management of stroke, books specifically directed at the treatment or prevention of depression, and those on stroke and old age.

\section{Data collection and analysis}

\section{Selection of studies}

Two review authors (SA, MH) discarded irrelevant citations based on the title of the publication and its abstract. In the presence of any suggestion that an article could possibly be relevant, we retrieved the full-length article for further assessment. Two review authors (SA, MH) independently selected the trials for inclusion in the review from the culled citation list. We obtained translations of potentially relevant non-English articles. We resolved disagreements by discussion, and one review author (AH) confirmed the final list and adjudicated any persisting differences. The selection process is presented in a PRISMA flow diagram (Liberati 2009). We listed the included studies under Characteristics of included studies, and studies that we ultimately excluded under Characteristics of excluded studies and provided the primary reasons for exclusion.

\section{Data extraction and management}

Two review authors (SA, MH) extracted study characteristics and outcome data from included studies, independently, on specially designed forms. We cross-checked and entered the data into Review Manager 5 (Review Manager 2014). We obtained missing information from the study authors when possible. We resolved disagreements by discussion or through consultation with a third review author $(\mathrm{AH})$. If outcome data were not reported in a usable way, we reported this in the notes in the Characteristics of included studies table.

We collected data on:

- the report: author, year and source of publication;

- the study: sample characteristics, social demography, definition and criteria used for emotionalism;

- the participants: stroke sequence (first-ever versus recurrent), social situation, time since stroke onset, history of psychiatric illness, current neurological status, current treatment for depression, coronary artery disease;

- the research design and features: sampling mechanism, treatment assignment mechanism, adherence rates, nonresponse rates, length of follow-up;

- the intervention: type, duration, dose, timing, mode of delivery;

- the effect size: sample size, nature of outcome, estimate and standard error.

To allow an intention-to-treat analysis, we sought data irrespective of adherence, whether or not the participants were subsequently deemed ineligible, or otherwise excluded from treatment or followup.

We checked all of the extracted data for agreement between review authors. We obtained missing information from the study investigators whenever possible. To avoid introducing bias, we 
requested this unpublished information in writing, and then entered it into Review Manager 5 (Review Manager 2014).

\section{Assessment of risk of bias in included studies}

Two review authors (SA, MH) independently assessed risk of bias for each study using the criteria outlined in the Cochrane Handbook for Systematic Reviews of Interventions (Higgins 2011). We resolved any disagreements by discussion or by involving another author $(\mathrm{AH})$. We assessed the risk of bias according to the following domains.

- Random sequence generation.

- Allocation concealment.

- Blinding of participants and personnel.

- Blinding of outcome assessment.

- Incomplete outcome data.

- Selective outcome reporting.

- Other bias.

In accordance with the Cochrane 'Risk of bias' assessment tool, we graded potential sources of bias as high, low, or unclear and provided a quote from the study report together with justification for our judgement in the 'Risk of bias in included studies' table. We summarised the risk of bias judgements across different studies for each of the domains listed.

When considering treatment effects, we have taken into account the risk of bias for the studies that contributed to that outcome.

\section{Measures of treatment effect}

\section{Dichotomous data}

The primary outcomes of interest were the proportion of participants who met the diagnostic categories for emotionalism at the end of follow-up (with improved score on Center for Neurologic Study - Lability Scale (CNS-LS), Clinician InterviewBased Impression of Change (CIBIC), and diminished tearfulness), and the proportion that show a 50\% reduction in abnormal emotional behaviour (crying or laughing) at the end of treatment. For all dichotomous outcomes, we calculated Mantel-Haenszel risk ratios (RRs) with $95 \%$ confidence intervals (Cls) where appropriate, using random-effects analyses.

\section{Continuous data}

For continuous outcomes, if ordinal scale data appeared to be approximately normally distributed or if the analysis suggests parametric tests were appropriate, we treated the outcome measures as continuous. If there were at least two studies that reported the same outcomes, then we calculated a mean difference (MD) across the trials. Where different outcome measures were used, we planned to calculate a standardised mean difference (SMD).

\section{Unit of analysis issues}

No unit of analysis issues were anticipated in the studies we included.

\section{Dealing with missing data}

We wrote to the authors of all included studies requesting data that were unavailable or ambiguous in the published articles.
Three authors responded with the requested additional data (Andersen 1993; Murray 2005; Robinson 1993b). Another study author responded, stating that the requested additional data were unavailable (Burns 1999). We did not receive responses from the remaining study authors.

\section{Assessment of heterogeneity}

We assessed clinical and methodological heterogeneity by examining the study characteristics of studies. We used the 12 statistic to measure heterogeneity among the trials in each analysis (Deeks 2011). We reported similarities between interventions, participants, design, and outcomes in the Included studies subsection.

\section{Assessment of reporting biases}

We created funnel plots, however, due to the small number of included studies, these are unlikely to be useful in exploring possible small study biases for the primary outcome.

\section{Data synthesis}

We analysed data using Review Manager 5 software and pooled data for meta-analysis when studies assessed similar treatment and had similar outcomes (Review Manager 2014). We conducted a meta-analysis using available or calculated SMDs for continuous outcomes, and risk ratios (RRs) for dichotomous outcomes. We included in the results measures of uncertainty, such as $95 \% \mathrm{Cls}$ and estimates of 12 .

\section{Summary of findings and quality of the evidence}

We also assessed the quality of evidence according to GRADE (Atkins 2004), by constructing a 'Summary of findings' table for the main outcomes using the GRADEPro tool (GRADEproGDT 2015; Schunemann 2011). We reported the primary outcomes in 'Summary of findings for the main comparison'.

\section{Subgroup analysis and investigation of heterogeneity}

If there were at least two trials that reported the same outcomes, we reviewed the data for appropriateness of pooling. If there was definite evidence of heterogeneity $(12>50 \%)$, we explored the potential reasons for the differences by performing subgroup analyses. If the heterogeneity could not be explained, we combined the trials using random-effects analyses with cautious interpretation, or did not combine them at all. Where possible, we performed subgroup analyses to examine the impact of treatment type and duration, and of stroke severity.

\section{Sensitivity analysis}

We planned to undertake sensitivity analyses to explore the influence of date of publication, sample size, duration of follow-up, treatment type, high (over 20\%) number of dropouts, and blinded versus unblinded outcome assessors. We explored the sensitivity of the combined estimate to individual trials by leaving one study out due to high risk of bias and methodological differences. We then calculated the combined effect of the remaining trials, and compared the results with the combined effect based on all the trials. 


\section{RESULTS}

\section{Description of studies}

\section{Results of the search}

In total, we identified 2802 records, of these, we retrieved 2244 records through database searching. We found 558 additional references by searching other resources. After removing 559 duplicates, we screened 2243 titles and abstracts and excluded 2232 irrelevant records. We retrieved full-text reports for the remaining 11 studies. After reading the full-texts, we excluded 10 studies as they did not meet the review eligibility criteria. We have provided primary reasons for exclusion in the Characteristics of excluded studies table and in Figure 1. Although, one trial met the inclusion criteria, baseline evaluation of the study occurred at one month post-treatment (Kim 2017a); we considered this study a 'dropout' (Table 1). 
Figure 1. Study flow diagram.

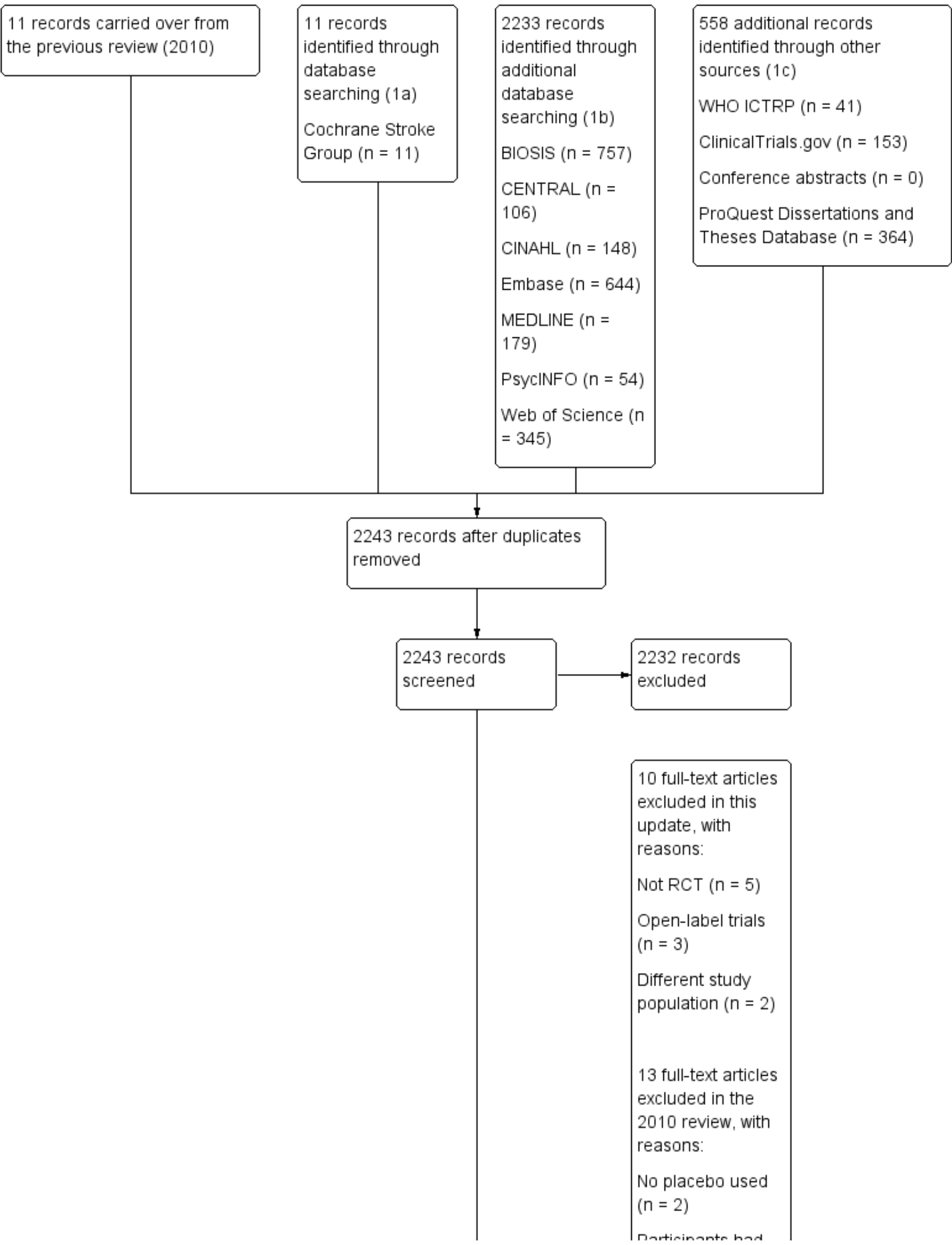


Figure 1. (Continued)

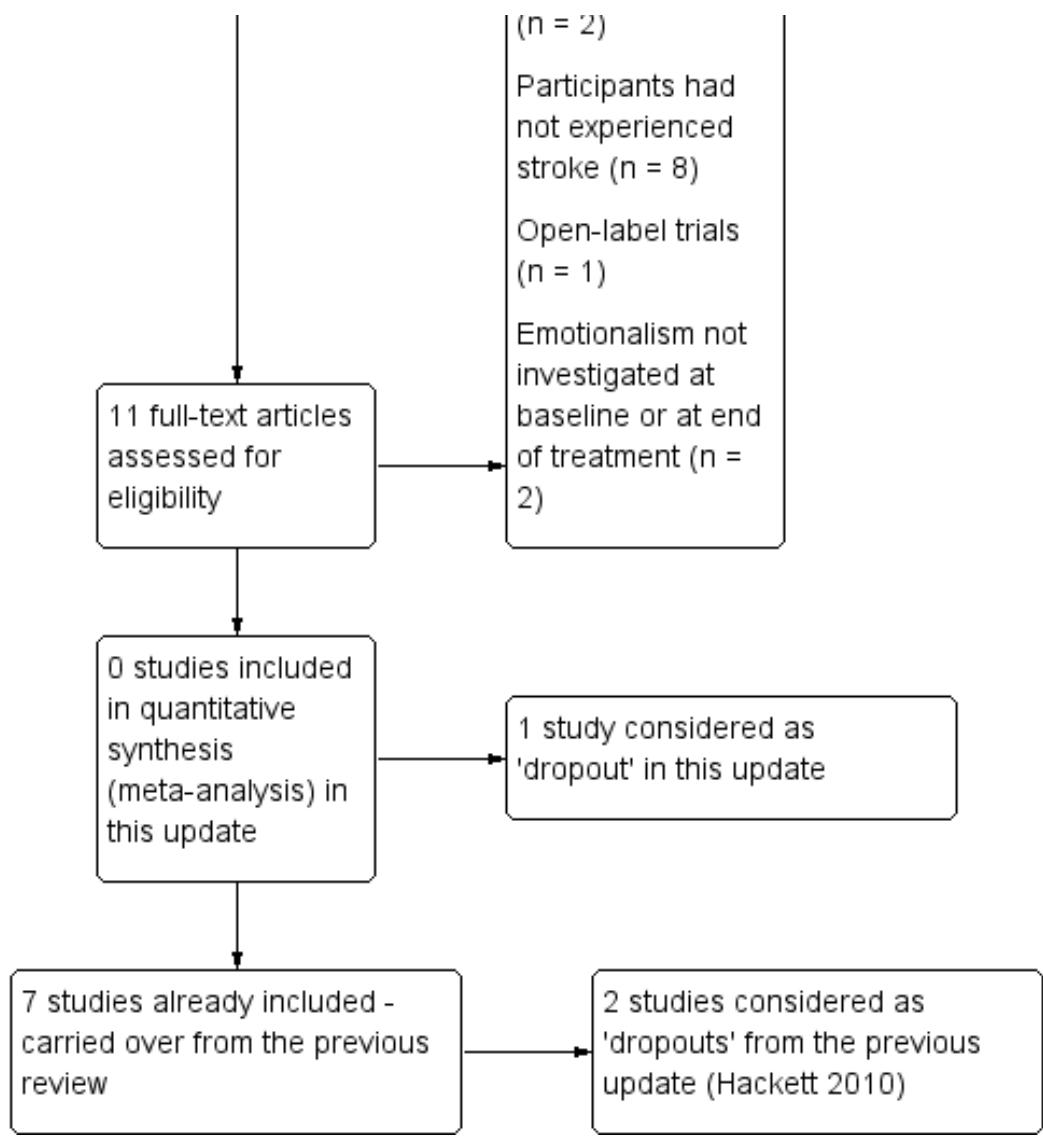

In the previous published version of this review (Hackett 2010), we identified two trials that met the inclusion criteria (Aizawa 1977; Ohtomo 1985). However, both trials included participants with cerebral arteriosclerosis and neither presented outcome data by those diagnosed with emotionalism at entry. We considered these two studies as 'dropouts'. See Table 1 for more detailed information on these trials.

\section{Included studies}

From the previous update of this review, there were a total of seven included studies with 239 participants (of whom we included 213 participants in the meta-analysis). Two trials were of cross-over design (Andersen 1993; Ohkawa 1989), and outcome data were not available from the first phase (precross-over) in an appropriate format for inclusion as a parallel randomised controlled trial (RCT). Therefore, this review primarily reports data from five trials with 213 participants (see Characteristics of included studies). Of these, we had included five studies in the first version of this review in 2004 (Andersen 1993; Brown 1998; Burns 1999; Ohkawa 1989; Robinson 1993b), and we added two studies to the previous update in 2010 (Choi-Kwon 2006; Murray 2005). For this present review, we found no new studies.

\section{Participants}

All trials in this review included men and women. The mean or median age of participants ranged from 57.8 to 73 years. Five trials reported the time between stroke and randomisation into the trial,

Pharmaceutical interventions for emotionalism after stroke (Review)

with the range covering three days to 13 years (Andersen 1993; Burns 1999; Murray 2005; Ohkawa 1989; Robinson 1993b).

\section{Interventions}

Five trials assessed the efficacy of SSRIs: citalopram (Andersen 1993), fluoxetine (Brown 1998; Choi-Kwon 2006), and sertraline (Burns 1999; Murray 2005); two assessed tricyclic antidepressants: amitriptyline (Ohkawa 1989), and nortriptyline (Robinson 1993b). Duration of treatment ranged from 10 to 182 days.

\section{Comparator intervention(s)}

Only one study did not compare the active intervention with a placebo-matched control, but combined the active treatment with a 'stomach medicine' to disguise taste and smell with the control group receiving the stomach medicine only (Ohkawa 1989).

\section{Outcomes}

\section{Primary outcome: emotionalism}

No standard criteria were used to define emotionalism at entry across the trials. Emotionalism was measured in seven different ways in the seven trials (Andersen 1993; Brown 1998; Burns 1999; Choi-Kwon 2006; Murray 2005; Ohkawa 1989; Robinson 1993b), and no more than two trials used the same method of assessment. Andersen 1993 assessed emotionalism using a semistructured interview modified from Lawson and Macleod. Brown 1998 used the Lawson-Mcleod Rating Scale. In Burns 1999, the presence or absence of emotionalism was assessed using seven questions based on the study by House et al (House 1989). Other 
studies confirmed the presence of emotionalism through clinical diagnosis made by a psychiatrist (Robinson 1993b), or asking the patients and their relatives whether or not increased tearfulness or inappropriate laughing has occurred at anytime (Choi-Kwon 2006), or on more than two occasions (Murray 2005).

\section{Secondary outcomes}

A variety of additional outcomes were assessed in each trial. Several trials assessed, but did not report, outcome data for depression (Andersen 1993; Brown 1998; Burns 1999; Ohkawa 1989), activities of daily living (Burns 1999), and cognitive functioning (Burns 1999; Ohkawa 1989). Only three studies reported having systematically measured and reported adverse events (Burns 1999; Choi-Kwon 2006; Murray 2005).

\section{Excluded studies}

We have listed the 23 excluded studies and the reasons for their exclusion in the Characteristics of excluded studies table. The main reasons for exclusion were no placebo used (Atarashi 1988; Bassi 1984; Muller 1999), participants had not experienced stroke, or the number with stroke was unclear (Aizawa 1977; Bassi 1984; Doody 2014; Lawson 1969; Ohtomo 1985; Otomo 1984; Sauve 2017; Udaka 1984), not a RCT (Allen 2018; Chen 2010; Colamonico 2012; Manzo
1998; Work 2011), open-label trials (D'Amico 2017; Formella 2017a; Formella 2017b; Seliger 1992), emotionalism was not investigated either at baseline (Rasmussen 2000), or at end of treatment (Moller 2007), and baseline evaluation of emotionalism occurred at one month post-treatment (Kim 2017a).

\section{Ongoing studies}

We identified no ongoing studies.

\section{Studies awaiting classification}

We identified no studies awaiting classification.

\section{New studies found at this update}

We identified no new studies in this update.

\section{Risk of bias in included studies}

We present Figure 2, a graphical summary of 'Risk of bias' assessments we performed for the seven included studies, based on the seven risk of bias domains. Figure 3 provides a summary of risk of bias for each included study. We have provided the reasons for judgements in the Risk of bias in included studies tables. For clarification, we have provided quotes in these tables.

Figure 2. Risk of bias graph: review authors' judgements about each risk of bias item presented as percentages across all included studies.

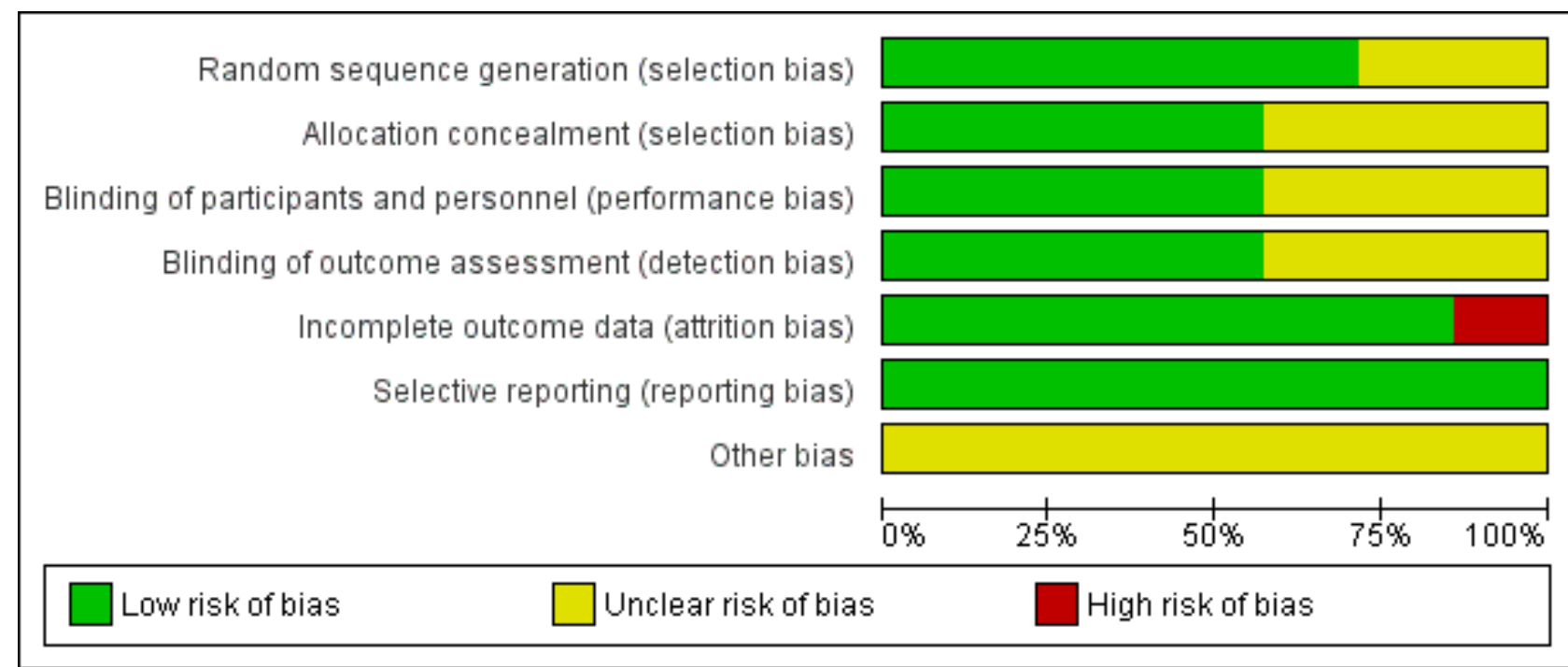


Figure 3. Risk of bias summary: review authors' judgements about each risk of bias item for each included study.

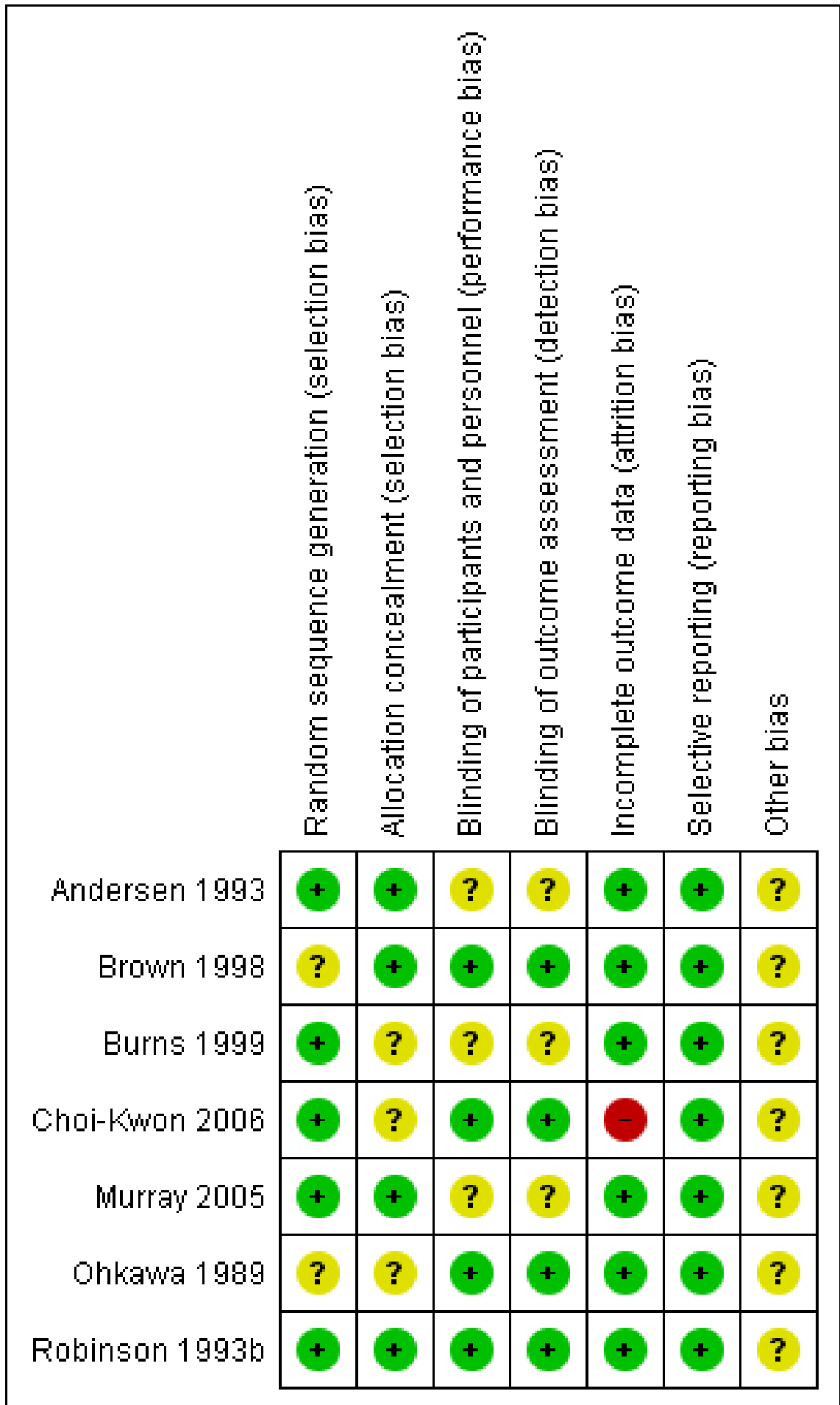

\section{Allocation}

We rated three studies as having a low risk of selection bias and four as having an unclear risk. Two of the studies did not report the method used for sequence generation (Brown 1998; Ohkawa 1989). Four studies randomised participants using a random number allocation list (Burns 1999), or computer-generated number sequence (Andersen 1993; Choi-Kwon 2006; Murray 2005).
One study administered the intervention after random number assignment (Robinson 1993b). Allocation concealment was clearly reported in four studies (Andersen 1993; Brown 1998; Murray 2005; Robinson 1993b). 


\section{Blinding}

We assessed blinding as having a low risk of performance and detection bias in four studies (Brown 1998; Choi-Kwon 2006; Ohkawa 1989; Robinson 1993b). Although three studies reported that they were double-blind, they failed to report exactly who was blinded (Andersen 1993; Burns 1999; Murray 2005).

\section{Incomplete outcome data}

We judged six of the studies as having a low risk of bias for outcome reporting (Andersen 1993; Brown 1998; Burns 1999; Murray 2005; Ohkawa 1989; Robinson 1993b). One study was at high risk, as the total number of participants stated is inconsistent. We rated studies as having a high risk of bias if dropout rates were uneven between groups and the reason for dropout was suspected to be related to group allocation. We also rated studies as high risk if investigators did not report how dropout was dealt with (e.g. intention-to-treat analysis and last observation carried forward).

\section{Selective reporting}

We rated risk of bias from selective reporting as low risk for all the studies (Andersen 1993; Brown 1998; Burns 1999; Choi-Kwon 2006; Murray 2005; Ohkawa 1989; Robinson 1993b).

\section{Other potential sources of bias}

We judged other risk of bias as unclear risk for all the studies as we did not detect other potential sources of bias; they reported their funding source.

\section{Effects of interventions}

See: Summary of findings for the main comparison Pharmaceutical interventions compared to placebo for emotionalism after stroke

There are seven trials with 239 participants. Two trials were of cross-over design and outcome data were not available from the first phase (precross-over) in an appropriate format for inclusion as a parallel randomised controlled trial (RCT). Thus, the results of the review were based on five trials with 213 participants. For details of the comparisons made for trials with outcome data, refer to the Data and analyses section. Labelling of the x-axis on the forest plots changes due to variation in the method of measurement and direction of the outcome scale.

\section{Primary outcome}

\section{Emotionalism}

We observed treatment effects on the primary endpoint of emotionalism: $50 \%$ reduction in emotionalism (risk ratio (RR) 16.50 95\% confidence interval (CI) 1.07 to $253.40 ; 1 \mathrm{RCT}, 19$ participants, very low-quality evidence; Brown 1998; Analysis 1.1, subgroup 1.1.1); improvements (reduction) in tearfulness (RR $2.18,95 \% \mathrm{Cl}$ 1.29 to 3.71 ; 3 RCTs, 164 participants, moderate-quality evidence; Burns 1999; Choi-Kwon 2006; Murray 2005; Analysis 1.1, subgroup 1.1.4); improved score on Center for Neurologic Study - Lability Scale (CNS-LS) and Clinician Interview-Based Impression of Change (CIBIC) (RR 1.44, 95\% Cl 0.95 to 2.19; 1 RCT, 28 participants, lowquality evidence; Burns 1999; Analysis 1.1); and lower (better) scores on the Pathological Laughter and Crying Scale (PLCS) (mean difference (MD) $8.40,95 \% \mathrm{Cl} 11.56$ to 5.24; $1 \mathrm{RCT}, 28$ participants, low-quality evidence; Robinson 1993b; Analysis 1.2, subgroup
1.2.1). The point estimates were consistent with large treatment effects for all five trials; however, the Cls were wide for three trials (Brown 1998; Burns 1999; Robinson 1993b), so it is possible that the treatment may have had only a small positive effect, or in the case of the one trial (Burns 1999), may even have had a small negative effect on two endpoints (see subgroups 1.1.2 and 1.1.4).

\section{Secondary outcomes}

\section{Depression}

The moderate reduction in depression that was observed between treatment groups at the end of one study (Robinson 1993b; Analysis 1.3, subgroup 1.3.1), has been mediated by the addition of a second study (Murray 2005), and is not apparent after controlling for differences in depression between groups at baseline (standardised mean difference (SMD) $0.82,95 \% \mathrm{Cl} 2.14$ to $0.51 ; 2$ RCTs, 72 participants) (see Analysis 1.4, subgroup 1.4.1, where the $\mathrm{Cl}$ includes unity and the possibility of a negative treatment effect).

\section{Cognitive functioning}

One study provided data concerning this outcome, revealing that pharmaceutical interventions had no effect on cognitive functioning (MD $0.30,95 \% \mathrm{Cl}-3.27$ to $2.67 ; 1 \mathrm{RCT}, 28$ participants; Robinson 1993b; Analysis 1.5) compared with placebo.

\section{Activities of daily living}

One study addressed activities of daily living and found no treatment effect on activities of daily living (MD 1.40, 95\% Cl -5.22 to 2.42; 1 RCT, 28 participants; Robinson 1993b; Analysis 1.6).

\section{Disadvantages of treatment}

Two studies systematically recorded and reported adverse events (Burns 1999; Murray 2005). Other studies provided selected data on some adverse events (Robinson 1993b), or those leaving the study early (Brown 1998; Choi-Kwon 2006).

\section{Death}

We saw no differences between groups with the six studies reporting deaths (RR 0.59, 95\% Cl 0.08 to 4.50; 6 RCTs, 172 participants, moderate-quality evidence; Andersen 1993; Brown 1998; Burns 1999; Murray 2005; Ohkawa 1989; Robinson 1993b; Analysis 1.7). Deaths occurred in two studies, one in each group (Burns 1999), and one death only in the placebo group (Murray 2005).

\section{All adverse events}

We saw no difference between groups. Confidence intervals were extremely wide and all included unity (see Analysis 1.8).

\section{Leaving the study early}

Two studies showed that participants allocated active treatment were less likely to leave the studies early (Choi-Kwon 2006; Murray 2005), three other studies showed participants allocated active treatment were more likely to leave the studies early, giving a pooled estimate of no effect. However, $\mathrm{Cls}$ were extremely wide (Brown 1998; Burns 1999; Choi-Kwon 2006; Robinson 1993b), and all included unity (see Analysis 1.9). 


\section{DISCUSSION}

\section{Summary of main results}

The results of this review indicate that antidepressants reduce the frequency and severity of crying episodes. While these findings appear straightforward, our conclusions are guarded because of several methodological deficiencies in the studies; we have downgraded the quality of the evidence accordingly (see Summary of findings for the main comparison). These deficiencies include the type of participants included, the definition and diagnosis of emotionalism used, the inclusion of some comorbidities, the small number of trials and participants contributing to most endpoints, and the generally poor trial design and reporting of results.

In general, clinical trials are carried out on selected groups of individuals, while the usefulness of the information derived lies primarily in the ability to generalise the data to a wide range of individuals. This review included trials with participants whose index stroke varied from six days to 13 years before randomisation. It may not be appropriate to consider that the response to treatment is consistent across such mixed populations as the aetiology (and underlying pathology) of emotionalism may differ between patients early after acute stroke and those who survive in the long term. For example, survivors in the acute phase have recently experienced a potentially life-threatening event and are coping with the psychological consequences, as well as recovering from the disabling effects of the stroke itself. On the other hand, survivors of stroke at several months or longer after the event are adjusting to the prospects of long-term disability and changes in social and financial circumstances, as well as the cumulative effects of cerebrovascular disease or vascular dementia, or both. The natural history of emotionalism after stroke is for spontaneous resolution over a few months, whereas it is reasonable to suppose that it may be a more chronic state in those with chronic cerebrovascular disease. Therefore, since the balance of risks and benefits and the effectiveness of treatment for emotionalism may change with time from the onset of stroke, mixing individuals at very different stages after stroke makes interpretation difficult. Future trials should include homogeneous patient groups with respect to time from the onset of stroke, or sufficient numbers of participants in the early and late stages after stroke.

Defining the disorder of interest is key to the conduct of a clinical trial. A widely agreed definition usually exists for most clinical conditions. However, no such standard definition is available for emotionalism. For example, it does not feature in a clearly defined way in the Diagnostic and Statistical Manual of Mental Disorders (DSM) (APA 1987; APA 1994; APA 2017), or International Classification of Diseases (ICD) (ICD 10). In the clinical setting the diagnosis is generally made during interview. The commonly accepted criteria for emotionalism include: 1 ) sudden onset of crying (and less commonly, laughing); 2) not under usual control (a change in behaviour has occurred); and 3) the crying is not simply an expression of depression or grief. Given the resource-intensive nature of conducting psychiatric interviews on all participants in clinical trials, we considered it acceptable to determine caseness during a psychiatric interview and to measure frequency and severity using a validated questionnaire. We used two standardised scales to assess emotionalism: the Pathological Laughter and Crying Scale (PLCS) (Robinson 1993b), and the Lawson and Macleod Scale (Lawson 1969). An attempt to validate the PLCS was made (Robinson 1993b), but neither scale has been externally validated using traditional methods. The 'severity' score on the PLCS includes items recording the quality of crying, not just frequency of occurrence. In the absence of a validated questionnaire, the most appropriate method to diagnose and determine severity of emotionalism is likely to be a simple and easily replicable assessment of the frequency of crying episodes, or laughing episodes (assessing these elements separately), combined with an a priori cut-off score for entry into the trial. The nature of precipitants should be assessed in separate questions to those assessing frequency of crying and laughing.

Emotionalism is known to be confounded by depression (House 1989). Tearfulness can be the result of an underlying depressive disorder. The inclusion of participants with depression and emotionalism limits our ability to draw conclusions regarding the treatment of emotionalism alone. While all included studies assessed depression, only two studies reported results (Murray 2005; Robinson 1993b). Ideally, future studies should limit inclusion to participants with emotionalism alone, or recruit sufficient participants to allow adjustment for depression in the results, and report the results from all questionnaires administered.

As is often noted in reviews of the literature, there were several deficiencies in trial methods that further limit our findings. First, most trials (with the exception of Ohtomo 1985) were small, with only three trials reporting adequate concealment of the randomisation sequence (Brown 1998; Choi-Kwon 2006; Murray 2005). The duration of treatment was short for most studies. Observational studies suggest that many cases of emotionalism resolve over the first months after stroke, so the impact of shortterm therapy may be difficult to assess. Furthermore, case histories report relapse in emotionalism upon withdrawal of treatment, so it would be useful to have information on longer-term results and relapse rates in future studies. We also included cross-over studies if the washout period was deemed appropriate. While the benefits and risks of treatment with antidepressants appear to be balanced, only one trial systematically recorded and reported all adverse events in the study, making an accurate presentation of the benefits and risks impossible (Burns 1999).

In summary, these trials appear to add little to case reports and case series. They provide suggestive, but not definitive, evidence that antidepressants can reduce the frequency of crying (sometimes abolishing it altogether). The effect does not seem specific to one drug or class of drugs.

\section{Overall completeness and applicability of evidence}

The present review included seven trials with a total of 239 participants (Andersen 1993; Brown 1998; Burns 1999; Choi-Kwon 2006; Murray 2005; Ohkawa 1989; Robinson 1993b). Two trials were of cross-over design (Andersen 1993; Ohkawa 1989), and outcome data were not available from the first phase (precross-over) in an appropriate format for inclusion as a parallel randomised controlled trial (RCT). Thus, the results of the review were based on five trials with 213 participants. Overall, there were no standard criteria for defining emotionalism at entry and no standard measures of emotionalism across all the included studies. We considered three studies as 'dropouts' as outcome data were not available in the format appropriate for a parallel RCT and baseline was completed post-treatment. As a result, there were a small number of studies and participants contributing to most endpoints. The accuracy of the findings of this systematic review and meta- 
analysis is based on the studies which met the eligibility criteria. We will incorporate new data in future updates.

\section{Quality of the evidence}

We rated the quality of evidence for all comparisons using the five GRADE considerations (study limitations, consistency of effect, indirectness, imprecision and publication bias; Schunemann 2011). We created a 'Summary of findings' table. Quality assessment ranged from very low to moderate.

\section{Limitations in study design or execution}

Concerning the comparison of pharmaceutical interventions with placebo for diminished tearfulness, we downgraded the quality of evidence by one point for strong suspicions of attrition bias, related to the inconsistency in the total number of participants included in the analysis.

\section{Inconsistency of results}

We downgraded the quality of evidence by two points for the following outcomes: $50 \%$ reduction in emotionalism, improved score on Center for Neurologic Study - Lability Scale (CNS-LS), Clinician Interview-Based Impression of Change (CIBIC), and PLCS scores, as there were fewer than 50 participants and only one trial contributing to the analysis on each of these outcomes.

\section{Indirectness of evidence}

All included studies addressed the main review question (PICO): the effect of pharmaceutical interventions compared to placebo in reducing the frequency of emotionalism and emotional displays poststroke. Thus, we did not downgrade any outcomes in any comparisons for indirectness of evidence.

\section{Imprecision}

We downgraded the quality of evidence for $50 \%$ reduction in emotionalism and death by one point owing to wide confidence intervals.

\section{Publication bias}

We did not downgrade the quality of evidence for publication bias in any of the outcomes, as we did not detect publication bias.

\section{Potential biases in the review process}

\section{Strengths and weaknesses of this review}

This review has rigorously adhered to the Cochrane methods for performing systematic reviews. During the review process, we have tried to avoid and minimise any biases. We undertook extensive searches of databases and additional resources. We did not apply any language restrictions within the search process. Thus, we believe that we have identified and included all potentially relevant studies in this review. We arranged for any relevant and nonrelevant non-English full-text studies to be translated into English, to finalise the eligibility process. Furthermore, at least two review authors independently extracted and managed the data.

The main weakness of this review is the inadequate reporting of some of the studies, which has precluded classification of risk of bias as either low or high risk. This has led us to rate some of the studies across the categories at unclear risk of bias, with a small number of studies and participants contributing to most endpoints.

\section{Agreements and disagreements with other studies or reviews}

To date, there are no similar meta-analyses investigating the use of pharmacological interventions in reducing the frequency of emotional displays in people with emotionalism after stroke, with which to compare our findings.

\section{AUTHORS' CONCLUSIONS}

\section{Implications for practice}

Antidepressants may reduce the frequency of emotionalism after stroke. However, there is continued uncertainty about who might benefit the most from treatment among those who meet the clinical features indicative of emotionalism. There are no data to guide recommendations about how long patients should remain on treatment, or what side effects may be expected. Given the limited evidence, clinicians and patients may consider a therapeutic trial of antidepressants when emotionalism is persistent and severe.

\section{Implications for research}

We recommend that future trials investigating the effect of antidepressants in people with emotionalism after stroke should:

- use a standardised method to diagnose emotionalism, determine severity and assess change over time: this would assume development of a standard definition of emotionalism;

- use a standard measure of depression as the major confounder to be considered in analyses;

- recruit an adequate number of participants so that variables such as 'concomitant depression' and 'time passed between stroke and recruitment' can be controlled;

- provide treatment for a sufficient duration and follow-up, so that rates of relapse or maintenance of remission can be assessed;

- include careful assessment and complete reporting of adverse events;

- limit the number of outcomes to three or four and report results for all outcomes;

- make the outcomes relevant to the individual participant by, for example, being clear whether reduction in crying frequency or change in crying behaviour represented a satisfactory outcome for the participant;

- ensure the theoretical or biological rationale, or both, and sequential development of interventions follow a recommended framework for development, and if a framework is followed then it must be reported in the main study publications (Walker 2017);

- complete intervention descriptions to increase research usability, replicability, and development of standardised interventions, as an identified priority for the world stroke agenda (Walker 2017);

- adopt an implementation fidelity model or framework at the design stage (Walker 2017).

\section{ACKNOWLEDGEMENTS}

The review was supported by a grant from the Stroke Society of Australasia, with additional financial assistance provided by the Academic Unit of Psychiatry, University of Leeds, and the Centre for Clinical Brain Sciences, University of Edinburgh. The review authors 
thank Cochrane Stroke, particularly Brenda Thomas, for previously searching the Specialised Register of Cochrane Stroke and assisting with the development of the search strategies. We also thank Hazel
Fraser for assistance throughout the review process. We would also like to acknowledge Craig S Anderson, Judith A Horrocks, and Michelle Yang who contributed to earlier versions of this review. 
RE FE RE N CES

\section{References to studies included in this review}

Andersen 1993 \{published data only\}

Andersen G, Riis JO. Citalopram for post-stroke pathological crying. Lancet 1993;342(8875):837-9.

Andersen G, Vestergaard K, Riis JO. Citalopram for post-stroke pathological crying. Journal of Neurology 1994;241 Suppl 1:S81.

Andersen G, Vestergaard K, Riis JO. Pathological crying and emotional lability - a controlled study of citalopram - a SSRI. Canadian Journal of Neurological Sciences 1993;20 Suppl 4:S115.

* Andersen G, Vestergaard K, Riis JO. Post-stroke pathological crying or emotional affect treated with citalopram: a selective serotonin reuptake inhibitor. Acta Neurologica Scandinavica 1994;89:151.

Flicker C, Anderson G. Citalopram treatment of poststroke patients: improvement of uncontrolled crying. Journal of the American Geriatrics Society 1998;46(9):S67.

\section{Brown 1998 \{published data only\}}

Brown KW, Sloan RL, Pentland B. Fluoxetine as a treatment for post-stroke emotionalism. Acta Psychiatrica Scandinavica 1998;98(6):455-8.

\section{Burns 1999 \{published data only\}}

Burns A, Russell E, Stratton-Powell H. A pilot study to evaluate the efficacy of sertraline in the management of emotional lability following stroke. American Journal of Psychiatry. Toronto, Ontario, Canada, 1998:1.

* Burns A, Russell E, Stratton-Powell H, Tyrell P, O'Neill P, Baldwin R. Sertraline in stroke-associated lability of mood. International Journal of Geriatric Psychiatry 1999;14(8):681-5.

\section{Choi-Kwon 2006 \{published data only\}}

Choi-Kwon S, Choi J, Kwon SU, Kang DW, Kim JS. Fluoxetine improves the quality of life in patients with poststroke emotional disturbances. Cerebrovascular Diseases 2008;26(3):266-71. [PUBMED: 18648199]

Choi-Kwon S, Choi J, Kwon SU, Kang DW, Kim JS. Fluoxetine is not effective in the treatment of poststroke fatigue: a doubleblind, placebo-controlled study. Cerebrovascular Disease 2007;23(2-3):103-8.

Choi-Kwon S, Choi JM, Kwon DW, Kim JS. Fluoxetine improves QoL in patients with post-stroke emotional disturbances. International Journal of Stroke 2008;3(Suppl 1):405-6.

* Choi-Kwon S, Han SW, Kwon SU, Kang DW, Choi JM, Kim JS. Fluoxetine treatment in poststroke depression, emotional incontinence, and anger proneness: a double-blind, placebocontrolled study. Stroke 2006;37(1):156-61. [PUBMED: 16306470]
Choi-Kwon S, Kwon SU, Kang DW, Kim JS. Fluoxetine improves the quality of life in patients with post-stroke emotional disturbances. Stroke 2009;40(4):e282.

\section{Murray 2005 \{published and unpublished data\}}

Murray V, Von Arbin M, Asberg M, Bartfai A, Berggren A, Landtblom A, et al. Double-blind placebo comparison of sertraline and placebo in stroke patients with depression. Unpublished 2003.

Murray V, Von Arbin M, Varelius R, Olsson JE, Terent A, Samuelsson M, et al. Sertraline in poststroke depression: a controlled study. Stroke 2002;33(1):292.

* Murray V, von Arbin M, Bartfai A, Berggren AL, Landtblom AM, Lundmark J, et al. Double-blind comparison of sertraline and placebo in stroke patients with minor depression and less severe major depression. Journal of Clinical Psychiatry 2005;66(6):708-16. [PUBMED: 15960563]

\section{Ohkawa 1989 \{published data only\}}

Ohkawa S, Mori E, Yamadori A. Treatment of pathological laughing with amitriptyline. Rinsho Shinkeigaku [Clinical Neurology] 1989;29(9):1183-5.

Robinson 1993b \{published data only\}

* Parikh RM, Robinson RG, Lipsey JR, Price TR. Nortriptyline treatment of post-stroke emotional lability: a double blind study. Neurology 1989;39 Suppl 1:177.

Robinson R. Additional data provided by author. Unpublished 2003.

Robinson RG, Parikh RM, Lipsey JR, Starkstein SE, Price TR. Pathological laughing and crying following stroke: validation of a measurement scale and a double-blind treatment study. American Journal of Psychiatry 1993;150(2):286-93.

\section{References to studies excluded from this review}

\section{Aizawa 1977 \{published data only\}}

Aizawa T, Kase M, Kutsuzawa T, Hasegawa T, Sekimoto H, Omae T. Clinical evaluation on the effect of cyclandelate in the treatment of cerebrovascular diseases: double-blind comparative placebo-controlled clinical study with cinnarizine as a basic treatment. Rinsho Hyoka [Clinical Evaluation] 1977;5(3):659-86.

\section{Allen 2018 \{published data only\}}

Allen C, Zarowitz B, O'Shea T, Peterson E, Yonan C, Waterman F. Identification of pseudobulbar affect symptoms in the nursing home setting: development and assessment of a screening tool. Geriatric Nursing 2018;39(1):54-9.

\section{Atarashi 1988 \{published data only\}}

Atarashi J, Ohtomo E, Kogure K, Hirai S, Tazaki Y, Araki G, et al. Clinical utility of HYG-FAS in treatment of cerebrovascular disorders: multi-center double-blind study in comparison 
with hydergine tablet 2mg. Rinsho Hyoka [Clinical Evaluation] 1988;16(3):425-86.

\section{Bassi 1984 \{published data only\}}

Bassi S, Albizzati MG, Sbacchi M, Frattola L. Chronic cerebrovascular disorders: clinical study with cyclandelate. British Journal of Clinical Practice 1984;38:344-9.

\section{Chen 2010 \{published data only\}}

Chen YR, Huang YP, Lin SJ, Kuan TH, Lin CH. Effectiveness of quetiapine for poststroke pathological laughing: case report and review of literature. Clinical Neuropharmacology 2010;33(6):319-22.

\section{Colamonico 2012 \{published data only\}}

Colamonico J, Formella A, Bradley W. Psuedobulbar affect: burden of illness in the USA. Advances in Therapy 2012;29(9):775-98.

\section{D'Amico 2017 \{published data only\}}

D'Amico S, Alexander DN, Cutler AJ, Zorowitz RD, Davis CS, Shin P, et al. Safety and tolerability of dextromethorphan/ quinidine in older patients. American Journal of Geriatric Psychiatry 2017;25(3 Suppl 1):S142.

\section{Doody 2014 \{published data only\}}

Doody RS, D'Amico S, Cutler AJ, Shin P, Ledon F, Yonan C, et al. Safety, tolerability and effectiveness of dextromethorphan/ quinidine for pseudobulbar affect in patients with Alzheimer's Disease/Dementia: PRISM-II. Annals of Neurology 2014;76(Suppl 18):S99-S100.

\section{Formella 2017a \{published data only\}}

Formella AE, Alexander DN, Cutler AJ, D'Amico S, Hammond FM, Sauve W, et al. Dextromethorpha/quinidine improved symptoms of pseudobulbar affect irrespective of concomitant antidepressant use. CNS Spectrums 2017;22(1):64-5.

\section{Formella 2017b \{published data only\}}

Formella AE, Alexander DN, Cutler AJ, D'Amico S, Hammond FM, Sauve W, et al. Dextromethorphan/quinidine improved symptoms of pseudobulbar affect irrespective of concomitant antidepressant use. Neurology 2017;88(Suppl 1):1-2.

\section{Kim 2017a \{published data only\}}

* Kim JS, Lee EJ, Chang DI, Park JH, Ahn SH, Cha JK, et al. The efficacy of early administration of escitalopram on depressive and emotional symptoms and neurological dysfunction after stroke: a multicentre, double-blind, randomised, placebocontrolled study. Lancet Psychiatry 2017;4(1):33-41.

NCT01278498. The Preventive effect of escitalopram on depression and related emotional disorders in acute stroke patients. clinicaltrials.gov/ct2/show/NCT01278498 (date first received 19 January 2011).

\section{Kim 2017b \{published data only\}}

Kim JS. Management of post-stroke mood and emotional disturbances. Expert Review of Neurotherapeutics 2017;17(12):1179-88.

\section{Lawson 1969 \{published data only\}}

Lawson IR, MacLeod RD. The use of imipramine ("Tofranil") and other psychotropic drugs in organic emotionalism. British Journal of Psychiatry 1969;115(520):281-5.

\section{Manzo 1998 \{published data only\}}

Manzo JF, Health RL, Blonder LX. The interpersonal management of crying among survivors of stroke. Sociological Spectrum 1998;18(2):161-84.

\section{Moller 2007 \{published data only\}}

Moller M, Andersen G, Gjedde A. Serotonin 5HT1A receptor availability and pathological crying after stroke. Acta Neurologica Scandinavica 2007;116(2):83-90.

\section{Muller 1999 \{published data only\}}

Muller U, Murai T, Bauer-Wittmund T, Cramon DY. Paroxetine versus citalopram treatment of pathological crying after brain injury. Brain Injury 1999;13(10):805-11.

\section{Narushima 2002 \{published data only\}}

Narushima P, Kosier J, Robinson R. Preventing poststroke depression: a 12-week double-blind randomized treatment trial and 21-month follow-up. Journal of Nervous and Mental Disease 2002;190(5):296-303.

\section{Ohtomo 1985 \{published data only\}}

Ohtomo E, Kutsuzawa T, Araki G, Hirai S, Terashi A, Kuzuya F, et al. Clinical usefulness of tiapride on psychiatric symptoms caused by cerebrovascular disorders: a multi-center doubleblind study in comparison with inactive placebo. Rinsho Hyoka [Clinical Evaluation] 1985;13(2):295-332.

\section{Otomo 1984 \{published data only\}}

Otomo E, Saso S, Araki G, Hirai S, Atarashi J, Hasegawa K, et al. Clinical evaluation of amantadine hydrochloride (Symmetrel) in the treatment of cerebrovascular disorders with psychiatric symptoms: multi-center double-blind study in comparison with placebo. Rinsho Hyoka [Clinical Evaluation] 1984;12(2):321-67.

\section{Rasmussen 2000 \{published data only\}}

* Rasmussen A. A double blind controlled study of the influence of sertraline on the incidence of post stroke depression and on emotional lability [PhD Thesis]. Copenhagen (Denmark): University of Copenhagen, 2000.

Rasmussen A. A double-blind, placebo-controlled study of the prophylactic effect of sertraline in post stroke emotional lability. European Neuropsychopharmacology. Germany: Elsevier, 2000.

Rasmussen A. A double-blind, placebo-controlled study of the prophylactic effect of sertraline in post stroke emotional lability. Nordic Psychiatric Congress. Copenhagen, 25 August, 2000.

* Rasmussen A. Post-stroke emotional lability: a double-blind psychopharmacological treatment with sertraline. Nordic Journal of Psychiatry 2000;54:35.

Rasmussen A, Lunde M, Poulsen DL, Sorensen K, Qvitzau S, Bech P. A double-blind, placebo-controlled study of sertraline in the prevention of depression in stroke patients. Psychosomatics 2003;44(3):216-21. 
Sauve 2017 \{published data only\}

Sauve W, Alexander DN, Cutler AJ, D'Amico S, Hammond FM, Zorowitz RD, et al. Neurological and psychiatric comorbidities assessment in the PRISM II study of dextromethorphan/ quinidine for treatment of pseudobulbar affect. CNS Spectrums 2017;22(1):104.

\section{Schiffer 1985 \{published data only\}}

Schiffer RB, Herndon RM, Rudick RA. Treatment of pathologic laughing and weeping with amitriptyline. New England Journal of Medicine 1985;312(23):1480-2.

\section{Seliger 1992 \{published data only\}}

Seliger GM, Hornstein A, Flax J, Herbert J, Schroeder K. Fluoxetine improves emotional incontinence. Brain Injury 1992;6(3):267-70.

\section{Udaka 1984 \{published data only\}}

Udaka F, Yamao S, Nagata H, Nakamura S, Kameyama M. Pathologic laughing and crying treated with levodopa. Archives of Neurology 1984;41(10):1095-6.

\section{Work 2011 \{published data only\}}

Work SS, Colamonico JA, Bradley WG, Kaye RE. Pseudobulbar affect: an under-recognized and under-treated neurological disorder. Advances in Therapy 2011;28(7):586-601.

Yang 2015 \{published data only\}

Yang LPH, Deeks ED. Dextromethorphan/quinidine: a review of its use in adults with pseudobulbar affect. Drugs 2015;75(1):83-90.

\section{Additional references}

\section{Allman 1989}

Allman P. Crying and laughing after brain damage: a confused nomenclature. Journal of Neurology, Neurosurgery, and Psychiatry 1989;52(12):1439-40.

\section{Allman 1992a}

Allman P. Drug treatment of emotionalism following brain damage. Journal of the Royal Society of Medicine 1992;85(7):423-4.

\section{Allman 1992b}

Allman P, Marshall M, Hope A, Fairburn C. Emotionalism following stroke: development and reliability of a semistructured interview. International Journal of Methods in Psychiatric Research 1992;2:125-31.

\section{APA 1987}

American Psychiatric Association. Diagnostic and Statistical Manual of Mental Disorders: DSM-IIIR. Washington, DC: American Psychiatric Association, 1987.

\section{APA 1994}

American Psychiatric Association. Diagnostic and Statistical Manual of Mental Disorders: DSM-IV. Washington, DC: American Psychiatric Association, 1994.

\section{APA 2017}

American Psychiatric Association. Diagnostic and Statistical Manual of Mental Disorders. 5th Edition. Arlington VA: American Psychiatric Publishing, 2017.

\section{Atkins 2004}

Atkins D, Best D, Briss PA, Eccles M, Falck-Yitter Y, Flottorp G, et al. GRADE Working Group. Grading quality of evidence and strength of recommendations. BMJ 2004;328(7454):1490.

\section{Beck 1961}

Beck AT, Ward C, Mendelson M. An inventory for measuring depression. Archives of General Psychiatry 1961;4:561-71.

\section{Benedek 1995}

Benedek D, Peterson KA. Sertraline for treatment of pathological crying. American Journal of Psychiatry 1995;152(6):953-4

\section{Brookshire 1970}

Brookshire R. Control of "involuntary" crying behaviour emitted by a multiple sclerosis patient. Journal of Communication Disorders 1970;3(3):171-6.

\section{Calvert 1998}

Calvert T, Knapp P, House A. Psychological associations with emotionalism after stroke. Journal of Neurology, Neurosurgery and Psychiatry 1998;65(6):928-9.

\section{Deeks 2011}

Deeks JJ, Higgins JP, Altman DG, editors. Chapter 9: Analysing data and undertaking meta-analyses. In: Higgins JP, Green S, editor(s). Cochrane Handbook for Systematic Reviews of Interventions Version 5.1.0 (updated March 2011). The Cochrane Collaboration, 2011. Available from handbook.cochrane.org. The Cochrane Collaboration.

\section{Folstein 1975}

Folstein MF, Folstein SE, McHugh PR. 'Mini-Mental State': a practical method for grading the cognitive state of patients for the clinician. Journal of Psychiatric Research 1975;12(3):189-98.

\section{Gillespie 2016}

Gillespie D, Cadden AP, Lees R, West RM, Broomfield NM. Prevalence of psuedobulbar affect following stroke: A systematic review and meta-analysis. Journal of Stroke and Cerebrovascular Diseases 2016;25(3):688-94.

\section{Goldberg 1972}

Goldberg DP. The Detection of Psychiatric Illness by Questionnaire. Vol. 21, Oxford: Oxford University Press, 1972.

\section{Gompertz 1993}

Gompertz P, Pound P, Ebrahim S. The reliability of stroke outcome measurement. Clinical Rehabilitation 1993;7(4):290-6.

\section{GRADEproGDT 2015 [Computer program]}

McMaster University (developed by Evidence Prime). GRADEproGDT. Hamilton (ON): McMaster University (developed by Evidence Prime), 2015. 


\section{Hamilton 1960}

Hamilton M. Rating scale for depression. Journal of Neurology, Neurosurgery and Psychiatry 1960;23:56-62.

\section{Hanger 1993}

Hanger HC. Emotionalism after stroke. Lancet 1993;342(8881):1235-6.

\section{Higgins 2011}

Higgins JP, Green S, editor(s). Cochrane Handbook for Systematic Reviews of Interventions Version 5.1.0 (updated March 2011). The Cochrane Collaboration, 2011. Available from handbook.cochrane.org. John Wiley \& Sons.

\section{House 1989}

House A, Dennis M, Molyneux A, Warlow C, Hawton K. Emotionalism after stroke. BMJ 1989;298(6679):991-4.

\section{Hunt 1986}

Hunt SM, McEwen J, McKenna SP. Measuring Health Status. Beckenham: Croom Helm, 1986.

\section{ICD 10}

World Health Organization. The ICD-10 Classification of Mental and Behavioural Disorders: Clinical Descriptions and Diagnostic Guidelines. Geneva: World Health Organization, 1992.

\section{Kim 2000}

Kim JS, Choi-Kwon S. Post stroke depression and emotional incontinence. Neurology 2000;54(9):1805-10.

\section{Kim 2005}

Kim SW, Shin IS, Kim JM, Lim SY, Yang SJ, Yoon JS. Mirtazapine treatment for pathological laughing and crying after stroke. Clinical Neuropharmacology 2005;28(5):249-51.

\section{Lauterbach 1991}

Lauterbach E, Schweri M. Amelioration of pseudobulbar affect by fluoxetine. Journal of Clinical Psychopharmacology 1991;11:392-3.

\section{Liberati 2009}

Liberati A, Altman DG, Tetzlaff J, Mulrow C, Gotzsche PC, loannidis JP, et al. The PRISMA statement for reporting systematic reviews and meta-analyses of studies that evaluate health care interventions: explanation and elaboration. PLOS Medicine 2009;6(7):e1000100.

\section{Mahoney 1965}

Mahoney FI, Barthel DW. Functional evaluation: the Barthel Index. Maryland State Medical Journal 1965;14:61-5.

\section{Massey 1981}

Massey E, Lowe S. Lithium carbonate in pseudobulbar palsy. Annals of Neurology 1981;9(1):97.

\section{Montgomery 1979}

Montgomery SA, Asberg M. A new depression scale designed to be sensitive to change. British Journal of Psychiatry 1979;134:382-9.

\section{Moore 1997}

Moore S, Gresham L, Bromberg M, Kasarkis E, Smith R. A selfreport measure of emotional lability. Journal of Neurology, Neurosurgery and Psychiatry 1997;63(1):89-93.

\section{Mukand 1996}

Mukand J, Kaplan M, Senno RG, Bishop DS. Pathological crying and laughing: treatment with sertraline. Archives of Physical Medicine and Rehabilitation 1996;77(12):1309-11.

\section{Nahas 1998}

Nahas Z, Arlinghaus KA, Kotrla KJ, Clearman RR, George MS. Rapid response of emotional incontinence to selective serotonin reuptake inhibitor. Journal of Neuropsychiatry and Clinical Neurosciences 1998;10:453-5.

\section{Newsom-Davis 1999}

Newsom-Davis I, Abraham S, Goldstein L, Leigh P. The emotional lability questionnaire: a measure of emotional lability in amyotrophic lateral sclerosis. Journal of the Neurological Sciences 1999;169(1-2):22-5.

\section{Panzer 1992}

Panzer MJ, Mellow AM. Antidepressant treatment of pathological laughing or crying in elderly stroke patients. Journal of Geriatric Psychiatry and Neurology 1992;5(4):195-9.

\section{Poeck 1969}

Poeck K. Pathophysiology of emotional disorders associated with brain damage. In: Vinken PJ, Bruyn GW editor(s). Handbook of Clinical Neurology. Holland: Holland Publishing Co, 1969:343-67.

\section{Review Manager 2014 [Computer program]}

Nordic Cochrane Centre, The Cochrane Collaboration. Review Manager 5 (RevMan 5). Version 5.3. Copenhagen: Nordic Cochrane Centre, The Cochrane Collaboration, 2014.

\section{Robinson 1993a}

Robinson RG, Parikh RM, Lipsey JR, Starkstein SE, Price TR. Pathological laughing and crying following stroke: validation of a measurement scale and a double-blind treatment study. American Journal of Psychiatry 1993;150(2):286-93.

\section{Sacco 2008}

Sacco S, Sarà M, Pistoia F, Conson M, Albertini G, Carolei A. Management of pathologic laughter and crying in patients with locked-in syndrome: a report of 4 cases. Archives Physical Medicine and Rehabilitation 2008;89(4):775-8.

\section{Sandyk 1985}

Sandyk R, Gillman MA. Nomifensine for emotional incontinence in the elderly. Clinical Neuropharmacology 1985;8(4):377-8.

\section{Schiffer 1983}

Schiffer R, Cash J, Herndon R. Treatment of emotional lability with low dosage tricyclic antidepressants. Psychosomatics 1983;24:1094-6. 


\section{Schunemann 2011}

Schunemann HJ, Oxman AD, Higgins JP, Vist GE, Glazziou P, Guyatt GH. Chapter 11: Presenting results and 'Summary of findings' tables. In: Higgins JP, Green S, editor(s). Cochrane Handbook for Systematic Reviews of Interventions Version 5.1.0 (updated March 2011). The Cochrane Collaboration, 2011. Available from handbook.cochrane.org. The Cochrane Collaboration.

\section{Seliger 1989}

Seliger GM, Hornstein A. Serotonin, fluoxetine, and pseudobulbar affect. Neurology 1989;39(10):1400.

\section{Sloan 1992}

Sloan RL, Brown KW, Pentland B. Fluoxetine as a treatment for emotional lability after brain injury. Brain Injury 1992;6(4):315-9.

\section{Smith 2003}

Smith AG, Montealegre-Orjuela M, Douglas JE, Jenkis EA. Venlafaxine for pathological crying after stroke. Journal of Clinical Psychiatry 2003;64(6):731-2.

\section{Tan 1996}

Tan I, Dorevitch M. Emotional incontinence: a dramatic response to paroxetine. Australian and New Zealand Journal of Medicine 1996;26(6):844.

\section{van Swieten 1998}

van Swieten JC, Koudstaal PJ, Visser MC, Schouten HJ, van Gijn J. Inter-observer agreement for the assessment of handicap in stroke patients. Stroke 1998;19(5):604-7.

\section{Walker 2017}

Walker MF, Hoffmann TC, Brady MC, Dean CM, Eng JJ, Farrin AJ, et al. Improving the development, monitoring and reporting of stroke rehabilitation research: Consensusbased core recommendations from the Stroke Recovery and

\section{CHARACTERISTICS OF STUDIES}

Characteristics of included studies [ordered by study ID]
Rehabilitation Roundtable. Neurorehabilitation and Neural Repair 2017;31(10-11):877-84.

\section{Ware 1993}

Ware JE, Snow KK, Kosinski M, Gandek B. SF-36 Health Survey: Manual and Interpretation Guide. Boston (MA): New England Medical Center, Health Institute, 1993.

\section{Wolf 1997}

Wolf J, Santana H, Thorpy M. Treatment of 'emotional incontinence' with levodopa. Neurology 1997;29:1935-6.

\section{Zigmond 1983}

Zigmond AS, Snaith RP. The Hospital Anxiety and Depression Scale. Acta Psychiatrica Scandanavica 1983;67(6):361-70.

\section{References to other published versions of this review Hackett 2010}

Hackett ML, Yang M, Anderson CS, Horrocks JA, House A. Pharmaceutical interventions for emotionalism after stroke. Cochrane Database of Systematic Reviews 2010, Issue 2. [DOI: 10.1002/14651858.CD003690.pub3]

\section{House 2002}

House AO, Anderson CS, Hackett ML, Horrocks JA. Interventions for emotionalism after stroke [Protocol]. Cochrane Database of Systematic Reviews 2002, Issue 3. [DOI: 10.1002/14651858.CD003690]

\section{House 2004}

House AO, Hackett ML, Anderson CS, Horrocks JA. Pharmaceutical interventions for emotionalism after stroke. Cochrane Database of Systematic Reviews 2004, Issue 2. [DOI: 10.1002/14651858.CD003690]

* Indicates the major publication for the study

Andersen 1993

Study design: randomised, cross-over design
Number of arms: 2
Experimental arm: citalopram $20 \mathrm{mg} /$ day if under 66 years old, $10 \mathrm{mg} /$ day if older
Control arm: placebo
Analysis: per protocol: 1 withdrawn (placebo), excluded from analysis; 2 early dropouts (placebo), last
value carried forward

Participants

\author{
Geographical location: Denmark \\ Setting: Aalborg Hospital \\ Number of participants: 16
}

Diagnosis: stroke, 6 to 913 days prior to randomisation 
Andersen 1993 (Continued)

Inclusion criteria: not specified

Exclusion criteria: 1) aphasia, (2) if participants or spouse is unable to keep a diary

Age: median age 58.5 years, range 40 to 83 years. Mean not reported

Sex: $88 \%$ men

Emotionalism criteria: involuntary outbursts of crying

Treatment: citalopram 20 mg daily if under 66 years old, 10 mg daily for older participants
Control: matched placebo
Cross-over details: 7 days baseline; 21 -day intervention; 7-day washout. 7-day baseline; 21-day intens
vention
Duration: treatment continued for 21 days
Washout period: 7 days + 7 days baseline registration
Outcomes
- Improvements in crying history
- Semi-structured interview (modified from Lawson and Macleod)
- Qualitative clinical evaluation of facial grimacing and concomitant crying
- Frequency of crying episodes (5-point scale; none to continuous)
- Context in which episodes occurred (3-point scale; non-specific to emotionally provoked)
- Recorded quantitative or qualitative data concerning crying (kept in a diary)
- Unwanted side effects (UKU side effects rating scale)
Compliance (examination of medical containers at the end of study)

Notes

Unable to use in analysis: interviewer-assessed no longer meet criteria for emotionalism - modified Lawson and Macleod scale, 50\% reduction in emotionalism, HDRS, leaving the study early, adverse events (data not reported in appropriate format)

\section{Risk of bias}

\begin{tabular}{lll}
\hline Bias & Authors' judgement & Support for judgement \\
\hline $\begin{array}{l}\text { Random sequence genera- } \\
\text { tion (selection bias) }\end{array}$ & Low risk & $\begin{array}{l}\text { Comments: participants were randomised in blocks of 4, sequence generated } \\
\text { by Lundbeck }\end{array}$ \\
\hline
\end{tabular}

Allocation concealment Low risk Comments: method of concealment was centralised
(selection bias)

\begin{tabular}{|c|c|c|}
\hline $\begin{array}{l}\text { Blinding of participants } \\
\text { and personnel (perfor- } \\
\text { mance bias) }\end{array}$ & Unclear risk & $\begin{array}{l}\text { Quote: "We investigated the effect of the selective serotonin reuptake inhibitor } \\
\text { citalopram on uncontrolled crying in stroke patients in a double-blind place- } \\
\text { bo-controlled crossover study" pp. } 837\end{array}$ \\
\hline All outcomes & & $\begin{array}{l}\text { Comments: the study authors stated that it is a double-blinded trial but no de- } \\
\text { tails of who were blinded were provided }\end{array}$ \\
\hline
\end{tabular}

\begin{tabular}{|c|c|c|}
\hline $\begin{array}{l}\text { Blinding of outcome as- } \\
\text { sessment (detection bias) } \\
\text { All outcomes }\end{array}$ & Unclear risk & $\begin{array}{l}\text { Quote: "We investigated the effect of the selective serotonin reuptake inhibitor } \\
\text { citalopram on uncontrolled crying in stroke patients in a double-blind place- } \\
\text { bo-controlled crossover study" pp. } 837\end{array}$ \\
\hline & & $\begin{array}{l}\text { Comments: the study authors stated that it is a double-blinded trial but no de- } \\
\text { tails of who were blinded were provided }\end{array}$ \\
\hline
\end{tabular}

\begin{tabular}{|c|c|c|}
\hline $\begin{array}{l}\text { Incomplete outcome data } \\
\text { (attrition bias) } \\
\text { All outcomes }\end{array}$ & Low risk & $\begin{array}{l}\text { Quote: "1 of the patients with classic pathological crying (no } 8 \text { ) was withdrawn } \\
\text { from study during the initial treatment period (placebo) because of a gener- } \\
\text { alised seizure on day } 28 ; 2 \text { others (no } 3 \text { and no } 9 \text { ) did not complete the second }\end{array}$ \\
\hline
\end{tabular}


treatment period (both placebo) because of lack of response to treatment after the first week" pp. 838

"In the latter cases the self-registered score in the first week was therefore used as the endpoint score" pp. 838

Comments: Dropouts or exclusions were detailed. Reason for dropouts or exclusions not related to group allocation. Method of how they dealt with the dropouts were provided

$\begin{array}{ll}\begin{array}{l}\text { Selective reporting (re- } \\ \text { porting bias) }\end{array} & \text { Low risk }\end{array}$

Other bias Unclear risk Comments: No other bias detected

\section{Brown 1998}

\begin{tabular}{|c|c|}
\hline Methods & $\begin{array}{l}\text { Study design: parallel, randomised controlled trial } \\
\text { Number of arms: } 2 \\
\text { Experimental arm: fluoxetine } 20 \mathrm{mg} / \text { day } \\
\text { Control arm: placebo } \\
\text { Analysis: per protocol; } 1 \text { withdrawn (treatment), excluded from analysis }\end{array}$ \\
\hline Participants & $\begin{array}{l}\text { Georgraphical location: Scotland } \\
\text { Setting: Astley Ainslie Hospital } \\
\text { Number of participants: } 20 \\
\text { Diagnosis: stroke, time from stroke to randomisation not reported } \\
\text { Inclusion criteria: 1) following a stroke who had a history of emotionalism at least } 4 \text { weeks' duration } \\
\text { Exclusion criteria: } 1 \text { ) cognitive impairment, } 2 \text { ) dysphasia, 3) major depressive disorder } \\
\text { Age: overall mean age not reported } \\
\text { Numbers included in treatment group: } 10 \text { participants (55\% men, mean age } 61.4 \text { years, SD } 8.6 \text { ) } \\
\text { Numbers included in control group: } 10 \text { participants (60\% men, mean age } 63.7 \text { years, SD 5.4) } \\
\text { Emotionalism criteria: emotionalism of at least } 4 \text { weeks duration assessed during semi-structured in- } \\
\text { terview using a modified Lawson and MacLeod rating scale, in addition to frequency of outbursts }\end{array}$ \\
\hline Interventions & $\begin{array}{l}\text { Treatment: fluoxetine } 20 \mathrm{mg} / \text { day } \\
\text { Control: matched placebo } \\
\text { Duration: treatment continued for } 10 \text { days }\end{array}$ \\
\hline Outcomes & $\begin{array}{l}\text { Outcomes } \\
\text { - Emotional outburst grade (modified Lawson and Macleod gradings) } \\
\text { - Depression (HDRS) } \\
\text { - Cognitive functioning (MMSE) } \\
\text { - Side effects (24-item checklist of possible symptoms) }\end{array}$ \\
\hline Notes & $\begin{array}{l}\text { Able to use in analysis } \\
\text { - } 50 \% \text { reduction in frequency of emotionalism outbursts }\end{array}$ \\
\hline
\end{tabular}


Brown 1998 (Continued)

- Leaving the study early

Unable to use in analysis: HDRS, Lawson and Macleod Scale, self-rating scales (mean and SD not presented)

Adverse events (data not presented)

\section{Risk of bias}

\begin{tabular}{lll}
\hline Bias & Authors' judgement & Support for judgement \\
\hline $\begin{array}{l}\text { Random sequence genera- } \\
\text { tion (selection bias) }\end{array}$ & Unclear risk & $\begin{array}{l}\text { Quote: "The patients were randomly allocated by an independent statistician } \\
\ldots \text { " pp.456 } \\
\text { Comments: participants were randomly allocated. Method of allocation not } \\
\text { detailed }\end{array}$ \\
\hline $\begin{array}{l}\text { Allocation concealment } \\
\text { (selection bias) }\end{array}$ & Low risk & $\begin{array}{l}\text { Quote: "The medication was repackaged so as to make the active and placebo } \\
\text { capsules identical to each other" pp. } 456\end{array}$ \\
\hline $\begin{array}{l}\text { Blinding of participants } \\
\text { and personnel (perfor- } \\
\text { mance bias) }\end{array}$ & Low risk & $\begin{array}{l}\text { Quote: "The patients, nursing staff and rating clinicians were blinded to the al- } \\
\text { lll outcomes }\end{array}$
\end{tabular}

Blinding of outcome as- Low risk sessment (detection bias)

Quote: "The patients, nursing staff and rating clinicians were blinded to the alAll outcomes location of active or placebo medication" pp. 456

$\begin{array}{ll}\begin{array}{l}\text { Incomplete outcome data } \\ \text { (attrition bias) }\end{array} & \text { Low risk } \\ \text { All outcomes } & \begin{array}{l}\text { Quote: "One patient had to be withdrawn because he developed a generalised } \\ \text { rash on active ..." pp. } 456\end{array} \\ & \begin{array}{l}\text { Comments: dropouts or exclusions were detailed. Reason for dropouts or ex- } \\ \text { clusions not related to group allocation }\end{array}\end{array}$

\begin{tabular}{|c|c|c|}
\hline $\begin{array}{l}\text { Selective reporting (re- } \\
\text { porting bias) }\end{array}$ & Low risk & $\begin{array}{l}\text { Comments: all prespecified outcomes reported. No trial protocol available pri- } \\
\text { or to randomisation of first participant }\end{array}$ \\
\hline
\end{tabular}

Other bias Unclear risk Comments: no other bias detected

Burns 1999

$\begin{array}{ll}\text { Methods } & \text { Study design: parallel, randomised controlled trial } \\ & \text { Number of arms: } 2 \\ & \text { Experimental arm: sertraline } 50 \mathrm{mg} / \text { day } \\ & \text { Control arm: placebo } \\ \text { Analysis: intention-to-treat: } 2 \text { withdrawn and } 1 \text { death (treatment), } 1 \text { death (placebo), last value carried } \\ \text { forward }\end{array}$


Burns 1999 (Continued)

Inclusion criteria: 1) clinically documented stroke (with or without computed tomography evidence of infarction), 2) presence of lability of mood observed by the referring clinician, 3) at least 1 month having elapsed since stroke, 4) absence of depression and dementia according to DSM-III-R criteria

Exclusion criteria: 1) less than 1 month since stroke, 2) depression or dementia using DSM-III-R criteria

Age: overall mean age not reported

Numbers included in treatment group: 14 (36\% men, mean age 73 years, SD 9.1)

Numbers included in control group: 14 (57\% men, mean age 67.6 years, SD 8.5)

Emotionalism criteria: lability of mood observed by referring clinician

\begin{tabular}{ll}
\hline Interventions & Treatment: sertraline $50 \mathrm{mg} /$ day \\
& Control: matched placebo \\
& Duration: treatment continued for 8 weeks \\
\hline
\end{tabular}

Outcomes

Primary outcomes

- Emotionalism/Lability of mood (Lability scale, House 1989)

- Episodes of tearfulness (4-point rating scale; 0: 1 episode less than once per week; 1: episodes more than once a week but less than once a day; 2: episodes up to 5 times a day; 3 : episodes 6 or more times a day)

- $\mathrm{CIBIC}$ rating scale

Secondary outcomes

- Cognitive functioning (MMSE)

- Depression (MADRS)

- Physical functional ability (Barthel Index)

- Severity of stroke (Scandinavian Stroke Scale)

- Language dysfunction (Frenchay Aphasia Battery)

\begin{tabular}{ll}
\hline Notes & Able to use in analysis \\
- Improved score on Lability scale (House 1989) \\
- Improved score on CIBIC \\
- Liminished tearfulness \\
- Deaving the study early \\
- Adverse events \\
Unable to use in analysis: MADRS, Barthel, MMSE (data not presented) \\
\hline
\end{tabular}

\section{Risk of bias}

\begin{tabular}{|c|c|c|}
\hline Bias & Authors' judgement & Support for judgement \\
\hline $\begin{array}{l}\text { Random sequence genera- } \\
\text { tion (selection bias) }\end{array}$ & Low risk & $\begin{array}{l}\text { Quote: "After randomization (in blocks of four using a random number alloca- } \\
\text { tion list produced by the Department of Medical Statistics...)" pp.683 }\end{array}$ \\
\hline $\begin{array}{l}\text { Allocation concealment } \\
\text { (selection bias) }\end{array}$ & Unclear risk & Comments: not detailed \\
\hline $\begin{array}{l}\text { Blinding of participants } \\
\text { and personnel (perfor- } \\
\text { mance bias) }\end{array}$ & Unclear risk & $\begin{array}{l}\text { Quote: "The study was carried out according to a double-blind placebo con- } \\
\text { trolled ..." pp. } 683\end{array}$ \\
\hline All outcomes & & $\begin{array}{l}\text { Comments: the study authors stated that it is a double-blinded trial but no de- } \\
\text { tails of who were blinded were provided }\end{array}$ \\
\hline
\end{tabular}


Burns 1999 (Continued)

Blinding of outcome as- Unclear risk Quote: "The study was carried out according to a double-blind placebo consessment (detection bias)

All outcomes

Comments: the study authors stated that it is a double-blinded trial but no details of who were blinded were provided

Incomplete outcome data Low risk (attrition bias)

All outcomes

Quote: "Four patients did not complete the study. Two withdrew in the sertra-

line group ..." pp. 683

"Results are presented on an intention to treat basis, with the last observation carried forward...." pp. 683

Comments: dropouts or exclusions were detailed. Reason for dropouts or exclusions not related to group allocation. Method of how they dealt with the dropouts were provided

\begin{tabular}{|c|c|c|}
\hline $\begin{array}{l}\text { Selective reporting (re- } \\
\text { porting bias) }\end{array}$ & Low risk & $\begin{array}{l}\text { Comments: all prespecified outcomes reported. No trial protocol available pri- } \\
\text { or to randomisation of first participant }\end{array}$ \\
\hline
\end{tabular}

Other bias Unclear risk Comments: no other bias detected

Choi-Kwon 2006

Methods Study design: parallel design

Number of arms: 2

Experimental arm: fluoxetine $20 \mathrm{mg} /$ day

Control arm: placebo

Analysis: intention-to-treat: 3 withdrawn (placebo), last value carried forward

Per protocol was also performed to investigate the consistency of the results

Participants Geographical location: South Korea

Setting: Asan Medical Centre

Number of participants: 92

Diagnosis: stroke, time from stoke to randomisation not reported Inclusion criteria: not specified

Exclusion criteria: 1) did not undergo imaging (CT/MRI) studies, 2) had subarachnoid haemorrhage, 3) had transient ischaemic attack without progression to stroke, 4 ) had communication problems (aphasia, dementia or dysarthria) severe enough as not to undergo a reliable interview, 5) were scored $<23$ on MMSE, 6) had a history of being diagnosed as having depression or other psychiatric illnesses before the onset of stroke, 7) had been already treated with psychiatric regimens including SSRI, and 8) lived alone so that information from the relatives was not available

Age: mean age not reported

Numbers of included in treatment group: $44^{\star}$ - age and sex of participants with excessive crying not reported

Numbers of included in control group: $48^{\star}$ - age and sex of participants with excessive crying not reported

${ }^{\star}$ Number stated is inconsistent in the report - we have reported data on excessive/inappropriate crying only, as represented in Table 3 of Choi-Kwon 2006 
Choi-Kwon 2006 (Continued)

Emotionalism criteria: emotionalism is present if both patients and relatives agreed that $\geq 2$ occasions of excessive or inappropriate laughing or crying or both has occurred as compared with their premorbid state

\begin{tabular}{ll}
\hline Interventions & $\begin{array}{l}\text { Treatment: fluoxetine } 20 \mathrm{mg} / \text { day } \\
\text { Control: matched placebo } \\
\text { Duration: treatment continued for } 3 \text { months } \\
\text { Assessments performed at enrolment, } 1 \text { month, } 3 \text { months, and } 6 \text { months }\end{array}$ \\
\hline Outcomes & Primary outcomes \\
- Presence poststroke depression (BDI score) \\
- Intenstiy of poststroke emotional incontinence (VAS) \\
- Presence of poststroke anger (Spielberger Trait Anger Scale) \\
Secondary outcomes \\
- Percentage changes in BDI scores for poststroke depression \\
- Percentage changes in VAS scores for emotional incontinence crying/laughing \\
- Patients' subjective responses as "aggravated", "no change" and "improved"
\end{tabular}

Notes
- Pate to use in analysis
- Leaving the study early
Unable to use in analysis: VAS for measuring extent of excessive or inappropriate laughing or crying
(data not presented in appropriate format). Percentage change of VAS between follow-ups (number of
emotionalism participants is inconsistent in report)
Adverse events (data for emotionalism participants not stated)

\section{Risk of bias}

\begin{tabular}{|c|c|c|}
\hline Bias & Authors' judgement & Support for judgement \\
\hline $\begin{array}{l}\text { Random sequence genera- } \\
\text { tion (selection bias) }\end{array}$ & Low risk & $\begin{array}{l}\text { Quote: "Treatment allocation was based on a computer generated list of treat- } \\
\text { ment numbers" pp.157 }\end{array}$ \\
\hline $\begin{array}{l}\text { Allocation concealment } \\
\text { (selection bias) }\end{array}$ & Unclear risk & Comments: not detailed \\
\hline $\begin{array}{l}\text { Blinding of participants } \\
\text { and personnel (perfor- } \\
\text { mance bias) } \\
\text { All outcomes }\end{array}$ & Low risk & $\begin{array}{l}\text { Quote: "The patient, relatives and researchers were not aware of the drug be- } \\
\text { ing given" pp. } 157\end{array}$ \\
\hline $\begin{array}{l}\text { Blinding of outcome as- } \\
\text { sessment (detection bias) } \\
\text { All outcomes }\end{array}$ & Low risk & $\begin{array}{l}\text { Quote: "The patient, relatives and researchers were not aware of the drug be- } \\
\text { ing given" pp. } 157\end{array}$ \\
\hline $\begin{array}{l}\text { Incomplete outcome data } \\
\text { (attrition bias) } \\
\text { All outcomes }\end{array}$ & High risk & $\begin{array}{l}\text { Quote: "Among } 152 \text { patients, } 27 \text { dropped out before completing the 3-month } \\
\text { treatment protocol ( } 15 \text { received fluoxetine, and } 12 \text { received placebo), leaving } \\
125 \text { patients. Although there was no difference in the dropout rate between } \\
\text { the } 2 \text { groups ..." pp. } 157 \\
\text { Comments: number of total participants stated is inconsistent }\end{array}$ \\
\hline
\end{tabular}


Choi-Kwon 2006 (Continued)

\begin{tabular}{|c|c|c|}
\hline $\begin{array}{l}\text { Selective reporting (re- } \\
\text { porting bias) }\end{array}$ & Low risk & $\begin{array}{l}\text { Comments: all prespecified outcomes reported. No trial protocol available pri- } \\
\text { or to randomisation of first participant }\end{array}$ \\
\hline
\end{tabular}

Other bias Unclear risk Comments: no other bias detected

\section{Murray 2005}

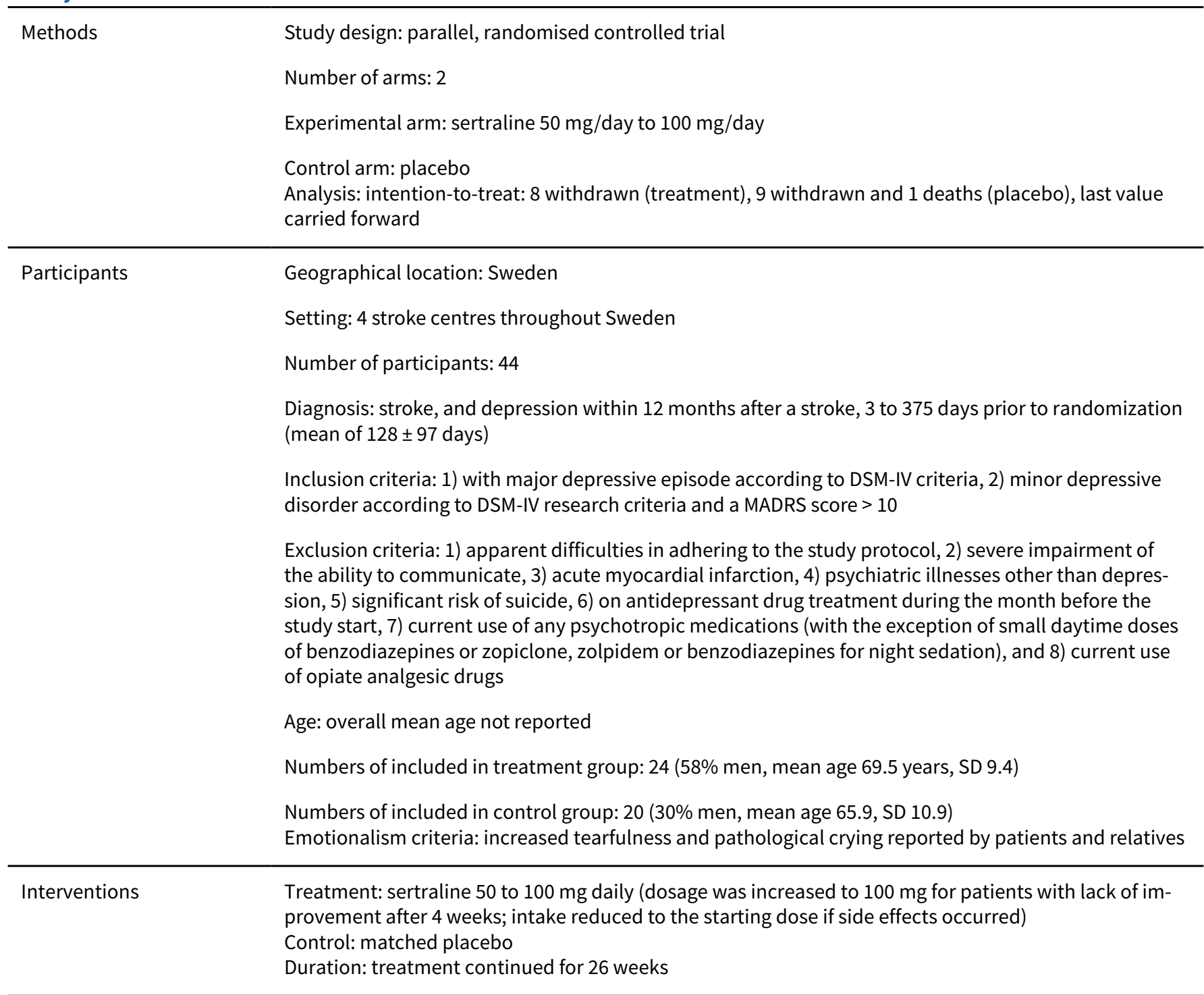

\begin{tabular}{ll}
\hline Outcomes & Primary outcome \\
- Change in MADRS & Secondary outcomes \\
- Response rate $>50 \%$ decrease in MADRS score \\
- Remission rate MADRS score $<1$
\end{tabular}

\section{Notes}

Able to use in analysis

- Presence or absence of emotionalism measured as a dichotomous variable 
Murray 2005 (Continued)

$$
\begin{aligned}
& \text { - MADRS } \\
& \text { - Leaving the study early } \\
& \text { - Death } \\
& \text { - Limited adverse events }
\end{aligned}
$$

\begin{tabular}{|c|c|c|}
\hline $\begin{array}{l}\text { Blinding of participants } \\
\text { and personnel (perfor- } \\
\text { mance bias) }\end{array}$ & Unclear risk & $\begin{array}{l}\text { Quote: "This } 26 \text {-week, double-blind, placebo-controlled study of sertraline } \\
\text { was carried out ..."pp. } 709\end{array}$ \\
\hline All outcomes & & $\begin{array}{l}\text { Comments: the study authors stated that it is a double-blinded trial but no de- } \\
\text { tails of who were blinded were provided }\end{array}$ \\
\hline
\end{tabular}

\begin{tabular}{|c|c|c|}
\hline $\begin{array}{l}\text { Blinding of outcome as- } \\
\text { sessment (detection bias) }\end{array}$ & Unclear risk & $\begin{array}{l}\text { Quote: "This } 26 \text {-week, double-blind, placebo-controlled study of sertraline } \\
\text { was carried out...."pp. } 709\end{array}$ \\
\hline
\end{tabular}

\section{Risk of bias}

\begin{tabular}{lll}
\hline Bias & Authors' judgement & Support for judgement \\
\hline $\begin{array}{l}\text { Random sequence genera- } \\
\text { tion (selection bias) }\end{array}$ & Low risk & Quote: "A centralized randomization procedure was applied". pp. 709 \\
\hline $\begin{array}{l}\text { Allocation concealment } \\
\text { (selection bias) }\end{array}$ & Low risk & $\begin{array}{l}\text { Quote: "Each centre pharmacy received a consecutive series of pre-sealed } \\
\text { treatment package. Patient received double-blind identical capsules of either } \\
\text { sertraline ..." pp. } 709\end{array}$
\end{tabular}
ction bias)

\begin{tabular}{|c|c|c|}
\hline $\begin{array}{l}\text { Selective reporting (re- } \\
\text { porting bias) }\end{array}$ & Low risk & $\begin{array}{l}\text { Comments: all prespecified outcomes reported. No trial protocol available pri- } \\
\text { or to randomisation of first participant }\end{array}$ \\
\hline
\end{tabular}

Comments: the study authors stated that it is a double-blinded trial but no details of who were blinded were provided

$\begin{array}{ll}\begin{array}{l}\text { Incomplete outcome data Low risk } \\ \text { (attrition bias) }\end{array} & \begin{array}{l}\text { Quote: "At week 6, } 11 \text { patients (18\%) in the sertraline group and } 6 \text { patients } \\ (10 \%) \text { in the placebo group had dropped out of the study (Figure 2). At week } \\ \text { All outcomes }\end{array} \\ \begin{array}{l}26, \text { an additional } 13 \text { patients (21\%) in the sertraline group and 24 patients } \\ (39 \%) \text { in the placebo group had been withdrawn. Of the 54 patients prema- } \\ \text { turely withdrawn, } 30 \text { had a major depressive episode and } 17 \text { a minor depres- } \\ \text { sive disorder. Lack of antidepressant effect was the reason for exclusion in } 38 \\ \text { cases and side effects in 13". }\end{array} \\ \begin{array}{l}\text { Comments: dropouts or exclusions were detailed. Reason for dropouts or ex- } \\ \text { clusions not related to group allocation. Method of how they dealt with the } \\ \text { dropouts were provided. Analysis was performed based on the intention-to- } \\ \text { treat principle }\end{array}\end{array}$

\begin{tabular}{lll}
\hline Other bias $\quad$ Unclear risk $\quad$ Comments: no other bias detected \\
\hline
\end{tabular}

\section{Ohkawa 1989}

\begin{tabular}{ll}
\hline Methods & Study design: cross-over, randomised controlled trial \\
Number of arms: 2 & \\
Experimental arm: amitriptyline $50 \mathrm{mg} /$ day \\
Control arm: bitter stomach medicine only \\
Analysis: per protocol: 2 withdrawn (treatment), 1 withdrawn (placebo), excluded from analysis \\
\hline Participants & Geographical location: Japan
\end{tabular}


Ohkawa 1989 (Continued)

Setting: hospital setting

Number of participants: 10

Diagnosis: mixed vascular group with lacunar state, 1 month to 2 years prior to randomisation Inclusion criteria: not specified

Exclusion criteria: not specified

Age: mean age 63.3 years, SD 7.2, range 51 to 73 years

Sex: $86 \%$ male

Emotionalism criteria: compulsive laughter alone or with compulsive crying, definition unclear

Interventions Treatment: amitriptyline $50 \mathrm{mg}$ daily, mixed with bitter stomach medicine to disguise taste and smell
Control: bitter stomach medicine only

Cross-over details: 3 weeks each of placebo and amitriptyline in random order Duration: treatment continued for 3 weeks

Outcomes
- Frequency of occurrence of compulsive laughter (classified into 4 classes: 0-none, 1-mild, only once,
2-moderate, a few times and 3-severe, frequent)
- Depression (Self-Rating Depression Scale)
- Cognitive functioning (MMSE)

\section{Notes}

Unable to use in analysis: no longer meet criteria for emotionalism, improved scores on frequency of compulsive laughter measure, leaving the study early, Self-Rating Depression Scale, MMSE (data not presented in appropriate format)

\section{Risk of bias}

\begin{tabular}{|c|c|c|}
\hline Bias & Authors' judgement & Support for judgement \\
\hline $\begin{array}{l}\text { Random sequence genera- } \\
\text { tion (selection bias) }\end{array}$ & Unclear risk & $\begin{array}{l}\text { Quote: "... and placebo were dosed in a random order (determined by the a } \\
\text { controller ..." pp. } 1184 \\
\text { Comments: method of randomisation not detailed }\end{array}$ \\
\hline $\begin{array}{l}\text { Allocation concealment } \\
\text { (selection bias) }\end{array}$ & Unclear risk & Comments: not detailed \\
\hline $\begin{array}{l}\text { Blinding of participants } \\
\text { and personnel (perfor- } \\
\text { mance bias) } \\
\text { All outcomes }\end{array}$ & Low risk & $\begin{array}{l}\text { Quote: "At examination, either the patients or nursing family members were } \\
\text { interviewed ..." pp. } 1184 \\
\text { Comments: the study stated that it is a double-blind placebo controlled trial }\end{array}$ \\
\hline $\begin{array}{l}\text { Blinding of outcome as- } \\
\text { sessment (detection bias) } \\
\text { All outcomes }\end{array}$ & Low risk & $\begin{array}{l}\text { Quote: "The examiner (other author), to whom the dosage order is un- } \\
\text { known ..." pp. } 1184 \\
\text { "Also a psychiatrist, to whom dosage is unknown, performed the self-rating } \\
\text { depression scale (SDS) ..." pp. } 1184\end{array}$ \\
\hline $\begin{array}{l}\text { Incomplete outcome data } \\
\text { (attrition bias) } \\
\text { All outcomes }\end{array}$ & Low risk & $\begin{array}{l}\text { Quote: "At first ten subjects was selected for the experiment, but three have } \\
\text { been excluded ..." pp. } 1184 \\
\text { Comments: dropouts or exclusions were detailed. Reason for dropouts or ex- } \\
\text { clusions not related to group allocation }\end{array}$ \\
\hline
\end{tabular}


Ohkawa 1989 (Continued)

\begin{tabular}{|c|c|c|}
\hline $\begin{array}{l}\text { Selective reporting (re- } \\
\text { porting bias) }\end{array}$ & Low risk & $\begin{array}{l}\text { Comments: all prespecified outcomes reported. No trial protocol available pri- } \\
\text { or to randomisation of first participant }\end{array}$ \\
\hline
\end{tabular}

Other bias Unclear risk Comments: no other bias detected

Robinson 1993b

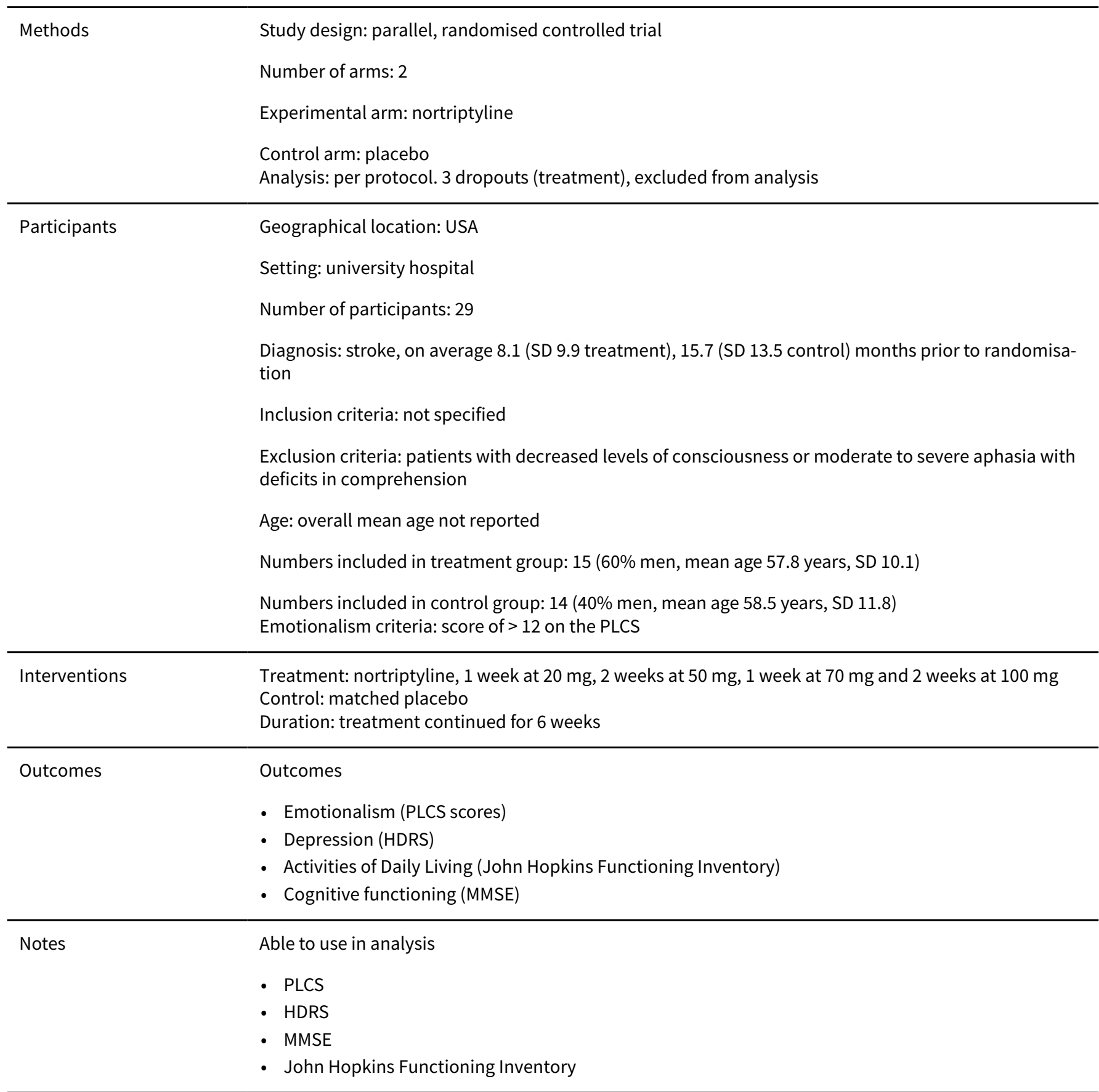

\section{Risk of bias}


Robinson 1993b (Continued)

Random sequence genera- Low risk Quote: "... in a single daily dose at bedtime after random number assigntion (selection bias) ment ..." pp. 287

Allocation concealment Low risk (selection bias)

Quote: "The 28 patients participating in the treatment study were given nortriptyline or placebo (in identical capsules) ..." pp. 287

Blinding of participants Low risk
and personnel (perfor-
mance bias)
All outcomes

\begin{tabular}{|c|c|c|}
\hline $\begin{array}{l}\text { Blinding of outcome as- } \\
\text { sessment (detection bias) }\end{array}$ & Low risk & $\begin{array}{l}\text { Quote: "Both the patients and the examiners were unaware of which treat- } \\
\text { ment was being given." pp. } 287\end{array}$ \\
\hline
\end{tabular}

All outcomes

Quote: "Both the patients and the examiners were unaware of which treatment was being given." pp. 287

Incomplete outcome data Low risk
(attrition bias)

All outcomes
Quote: "There was only one patient who dropped out during the course of the study". pp. 287
" ... dropped out between weeks 2 and 4 because of complaints of sedation." pp. 287
Comments: dropouts or exclusions were detailed. Reason for dropouts or ex- clusions not related to group allocation

\begin{tabular}{lll}
\hline $\begin{array}{l}\text { Selective reporting (re- } \\
\text { porting bias) }\end{array}$ & Low risk & $\begin{array}{l}\text { Comments: all prespecified outcomes reported. No trial protocol available pri- } \\
\text { or to randomisation of first participant }\end{array}$ \\
\hline Other bias & Unclear risk & Comments: no other bias detected \\
\hline
\end{tabular}

BDI: Beck Depression Inventory

CIBIC: Clinician Interview-Based Impression of Change

$\mathrm{CT}$ : computerised tomography

HDRS: Hamilton Depression Rating Scale

MADRS: Montgomery Asberg Depression Rating Scale

MMSE: Mini Mental State Examination

MRI: magnetic resonance imaging

PLCS: Pathological Laughter and Crying Scale

SD: standard deviation

VAS: Visual Analogue Scale

\section{Characteristics of excluded studies [ordered by study ID]}

\begin{tabular}{ll}
\hline Study & Reason for exclusion \\
\hline Aizawa 1977 & $\begin{array}{l}\text { Methods: double-blind RCT } \\
\text { Participants: cerebrovascular disorders (including arteriosclerosis) } \\
\text { Intervention: cyclandelate for } 4 \text { weeks } \\
\text { Outcomes: data not currently available for those with 'emotionalism' at baseline }\end{array}$ \\
\hline Allen 2018 & Methods: not a RCT, i.e. non-interventional, cross-sectional, case control study \\
& Participants: nursing home residents with documented diagnosis of pseudobulbar affect \\
Intervention: dextromethorphan/quinidine
\end{tabular}




\begin{tabular}{|c|c|}
\hline Study & Reason for exclusion \\
\hline & Intervention: no placebo comparison \\
\hline Bassi 1984 & $\begin{array}{l}\text { Methods: non-random, open-label } \\
\text { Participants: chronic cerebrovascular disorders } \\
\text { Intervention: no placebo comparison }\end{array}$ \\
\hline Chen 2010 & $\begin{array}{l}\text { Methods: not a RCT, i.e. case report and literature review } \\
\text { Intervention: quetiapine }\end{array}$ \\
\hline Colamonico 2012 & Methods: not a RCT, i.e. survey of to estimate the impact or burden of pseudobulbar affect \\
\hline D'Amico 2017 & Methods: non-random, open-label \\
\hline Doody 2014 & $\begin{array}{l}\text { Participants: ineligible study population, i.e. participants were adults who had pseudobulbar affect } \\
\text { after being diagnosed with dementia/Alzheimer's Disease }\end{array}$ \\
\hline Formella 2017a & Methods: non-random, open-label \\
\hline Formella 2017b & Methods: non-random, open-label \\
\hline Kim 2017a & Outcomes: data not currently available for those with 'emotionalism' at baseline pretreatment \\
\hline Kim 2017b & Methods: not a RCT, i.e. review of the most common poststroke mood and emotional disturbances \\
\hline Lawson 1969 & $\begin{array}{l}\text { Methods: randomised } \\
\text { Participants: hypertensive or ischaemic cerebral disease (number with stroke unclear) } \\
\text { Intervention: method of randomisation makes placebo comparison ineffectual - no appropriate } \\
\text { washout period }\end{array}$ \\
\hline
\end{tabular}

\begin{tabular}{ll}
\hline Manzo 1998 & Methods: not a RCT, i.e. qualitative study of pseudobulbar affect \\
\hline Moller 2007 & Methods: randomised \\
& Participants: patients with stroke and pathological crying \\
Intervention: citalopram for 30 days \\
Outcomes: emotionalism not investigated
\end{tabular}

Muller 1999 Methods: quasi-randomised, 2 active treatments

Participants: brain injury

Intervention: no placebo comparison

$\begin{array}{ll}\text { Narushima } 2002 & \text { Methods: double-blind, randomised } \\ & \text { Participants: poststroke } \\ & \text { Intervention: prevention of depression } \\ & \text { Outcomes: emotionalism not investigated }\end{array}$

Ohtomo 1985 Methods: double-blind, randomised

Participants: cerebrovascular disorders, including arteriosclerosis

Intervention: tiapride for 5 weeks

Outcomes: data not currently available for those with 'emotionalism' at baseline

\begin{tabular}{ll}
\hline Otomo 1984 & Methods: double-blind, randomised \\
& Participants: cerebrovascular disorders \\
Outcomes: emotionalism not investigated
\end{tabular}

Rasmussen $2000 \quad$ Methods: double-blind, randomised

Participants: poststroke without depression, emotionalism not assessed at baseline 


\begin{tabular}{ll}
\hline Study & Reason for exclusion \\
\hline Sauve 2017 & $\begin{array}{l}\text { Participants: ineligible study population, i.e. participants were adults who had pseudobulbar affect } \\
\text { after being diagnosed with dementia/Alzheimer's Disease }\end{array}$ \\
\hline Schiffer 1985 & $\begin{array}{l}\text { Methods: double-blind, cross-over } \\
\text { Participants: ineligible study population, i.e. multiple sclerosis (not stroke) }\end{array}$ \\
\hline Seliger 1992 & $\begin{array}{l}\text { Method: non-random, open-label } \\
\text { Participants: patients with stroke or multiple sclerosis (not stroke) and emotional incontinence }\end{array}$ \\
\hline Udaka 1984 & Methods: non-random, open-label \\
& Participants: ineligible study population, i.e. diffuse cerebrovascular disease (not stroke) \\
\hline Work 2011 & Methods: not a RCT, i.e. a survey to estimate the overall prevalence of pseudobulbar affect and \\
& quantify the extent to which it is diagnosed and treated \\
\hline Yang 2015 & Methods: not a RCT, i.e. a literature review \\
& Participants: adults with pseudobulbar affect \\
Intervention: dextromethorphan/quinidine
\end{tabular}

$\mathrm{RCT}$ : randomised controlled trial

DATA AND ANALYSES

Comparison 1. Pharmaceutical interventions versus placebo

\begin{tabular}{|c|c|c|c|c|}
\hline Outcome or subgroup title & $\begin{array}{l}\text { No. of } \\
\text { studies }\end{array}$ & $\begin{array}{l}\text { No. of } \\
\text { partici- } \\
\text { pants }\end{array}$ & Statistical method & Effect size \\
\hline 1 Emotionalism & 4 & & Risk Ratio (M-H, Random, 95\% Cl) & Subtotals only \\
\hline $1.150 \%$ reduction in emotionalism & 1 & 19 & Risk Ratio (M-H, Random, 95\% Cl) & $16.5[1.07,253.40]$ \\
\hline $\begin{array}{l}1.2 \text { Improved score on Lability scale } \\
\text { (House } 1989 \text { measure) }\end{array}$ & 1 & 28 & Risk Ratio (M-H, Random, 95\% Cl) & $1.44[0.95,2.19]$ \\
\hline $\begin{array}{l}1.3 \text { Clinician interview-based impression } \\
\text { of change - improved score }\end{array}$ & 1 & 28 & Risk Ratio (M-H, Random, 95\% Cl) & $1.44[0.95,2.19]$ \\
\hline 1.4 Diminished tearfulness & 3 & 164 & Risk Ratio (M-H, Random, 95\% Cl) & $2.18[1.29,3.71]$ \\
\hline $\begin{array}{l}2 \text { Emotionalism: mean scores at end of } \\
\text { treatment }\end{array}$ & 1 & & Mean Difference (IV, Fixed, 95\% CI) & Subtotals only \\
\hline $\begin{array}{l}\text { 2.1 Pathological Laughter and Crying } \\
\text { Scale (high score = worse emotionalism) }\end{array}$ & 1 & 28 & Mean Difference (IV, Fixed, 95\% CI) & $-8.4[-11.56,-5.24]$ \\
\hline $\begin{array}{l}3 \text { Depression: } 1 \text {. Mean scores at end of } \\
\text { treatment }\end{array}$ & 2 & 72 & $\begin{array}{l}\text { Std. Mean Difference (IV, Random, 95\% } \\
\text { CI) }\end{array}$ & $-0.82[-2.14,0.51]$ \\
\hline
\end{tabular}




\begin{tabular}{|c|c|c|c|c|}
\hline Outcome or subgroup title & $\begin{array}{l}\text { No. of } \\
\text { studies }\end{array}$ & $\begin{array}{l}\text { No. of } \\
\text { partici- } \\
\text { pants }\end{array}$ & Statistical method & Effect size \\
\hline $\begin{array}{l}\text { 3.1 Hamilton Depression Rating Scale } \\
\text { (high score = more depressed) }\end{array}$ & 1 & 28 & $\begin{array}{l}\text { Std. Mean Difference (IV, Random, 95\% } \\
\mathrm{Cl} \text { ) }\end{array}$ & $-1.53[-2.39,-0.67]$ \\
\hline $\begin{array}{l}\text { 3.2 Montgomery Asberg Depression Rat- } \\
\text { ing Scale (high score = more depressed) }\end{array}$ & 1 & 44 & $\begin{array}{l}\text { Std. Mean Difference (IV, Random, 95\% } \\
\mathrm{Cl} \text { ) }\end{array}$ & $-0.18[-0.77,0.42]$ \\
\hline $\begin{array}{l}4 \text { Depression: } 2 \text {. Average change in } \\
\text { scores between baseline and end of } \\
\text { treatment }\end{array}$ & 2 & 72 & $\begin{array}{l}\text { Std. Mean Difference (IV, Random, 95\% } \\
\mathrm{Cl} \text { ) }\end{array}$ & $-0.05[-0.72,0.62]$ \\
\hline $\begin{array}{l}\text { 4.1 Hamilton Depression Rating Scale } \\
\text { (high score = more depressed) }\end{array}$ & 1 & 28 & $\begin{array}{l}\text { Std. Mean Difference (IV, Random, 95\% } \\
\mathrm{Cl} \text { ) }\end{array}$ & $-0.43[-1.18,0.32]$ \\
\hline $\begin{array}{l}\text { 4.2 Montgomery Asberg Depression Rat- } \\
\text { ing Scale (high score = more depressed) }\end{array}$ & 1 & 44 & $\begin{array}{l}\text { Std. Mean Difference (IV, Random, 95\% } \\
\mathrm{Cl} \text { ) }\end{array}$ & $0.26[-0.34,0.85]$ \\
\hline $\begin{array}{l}5 \text { Cognitive functioning: mean scores at } \\
\text { end of treatment }\end{array}$ & 1 & & Mean Difference (IV, Fixed, 95\% CI) & Subtotals only \\
\hline $\begin{array}{l}\text { 5.1 Mini-mental state examination (low } \\
\text { score = cognitive impairment) }\end{array}$ & 1 & 28 & Mean Difference (IV, Fixed, 95\% CI) & $-0.30[-3.27,2.67]$ \\
\hline $\begin{array}{l}6 \text { Activities of daily living: } 1 . \text { Mean scores } \\
\text { at end of treatment }\end{array}$ & 1 & & Mean Difference (IV, Fixed, 95\% CI) & Subtotals only \\
\hline $\begin{array}{l}6.1 \text { Johns Hopkins Functioning Invento- } \\
\text { ry (high score = worse function) }\end{array}$ & 1 & 28 & Mean Difference (IV, Fixed, 95\% CI) & $-1.40[-5.22,2.42]$ \\
\hline 7 Adverse events: 1 . Death & 6 & & Risk Ratio (M-H, Random, 95\% Cl) & Subtotals only \\
\hline 7.1 At end of treatment & 6 & 172 & Risk Ratio $(\mathrm{M}-\mathrm{H}$, Random, 95\% Cl) & $0.59[0.08,4.50]$ \\
\hline 8 Adverse events: 2 . All & 2 & & Risk Ratio (M-H, Random, 95\% Cl) & Subtotals only \\
\hline $\begin{array}{l}\text { 8.1 Central nervous system events (e.g. } \\
\text { confusion, sedation, tremor) }\end{array}$ & 2 & 56 & Risk Ratio (M-H, Random, 95\% Cl) & $1.0[0.11,9.08]$ \\
\hline $\begin{array}{l}\text { 8.2 Gastrointestinal effects (e.g. consti- } \\
\text { pation, diarrhoea) }\end{array}$ & 1 & 28 & Risk Ratio (M-H, Random, 95\% Cl) & $0.33[0.01,7.55]$ \\
\hline $\begin{array}{l}8.3 \text { Other events not listed above (e.g. } \\
\text { dysuria, eye discomfort) }\end{array}$ & 1 & 28 & Risk Ratio (M-H, Random, $95 \% \mathrm{Cl}$ ) & $5.0[0.26,95.61]$ \\
\hline 8.4 Recurrent stroke & 1 & 28 & Risk Ratio (M-H, Random, 95\% Cl) & $1.0[0.07,14.45]$ \\
\hline $\begin{array}{l}9 \text { Adverse events: } 3 \text {. Leaving the study } \\
\text { early (including death) }\end{array}$ & 5 & & Risk Ratio (M-H, Random, 95\% Cl) & Subtotals only \\
\hline 9.1 All dropouts and withdrawals & 5 & 216 & Risk Ratio (M-H, Random, 95\% Cl) & $1.17[0.38,3.58]$ \\
\hline
\end{tabular}


Analysis 1.1. Comparison 1 Pharmaceutical interventions versus placebo, Outcome 1 Emotionalism.

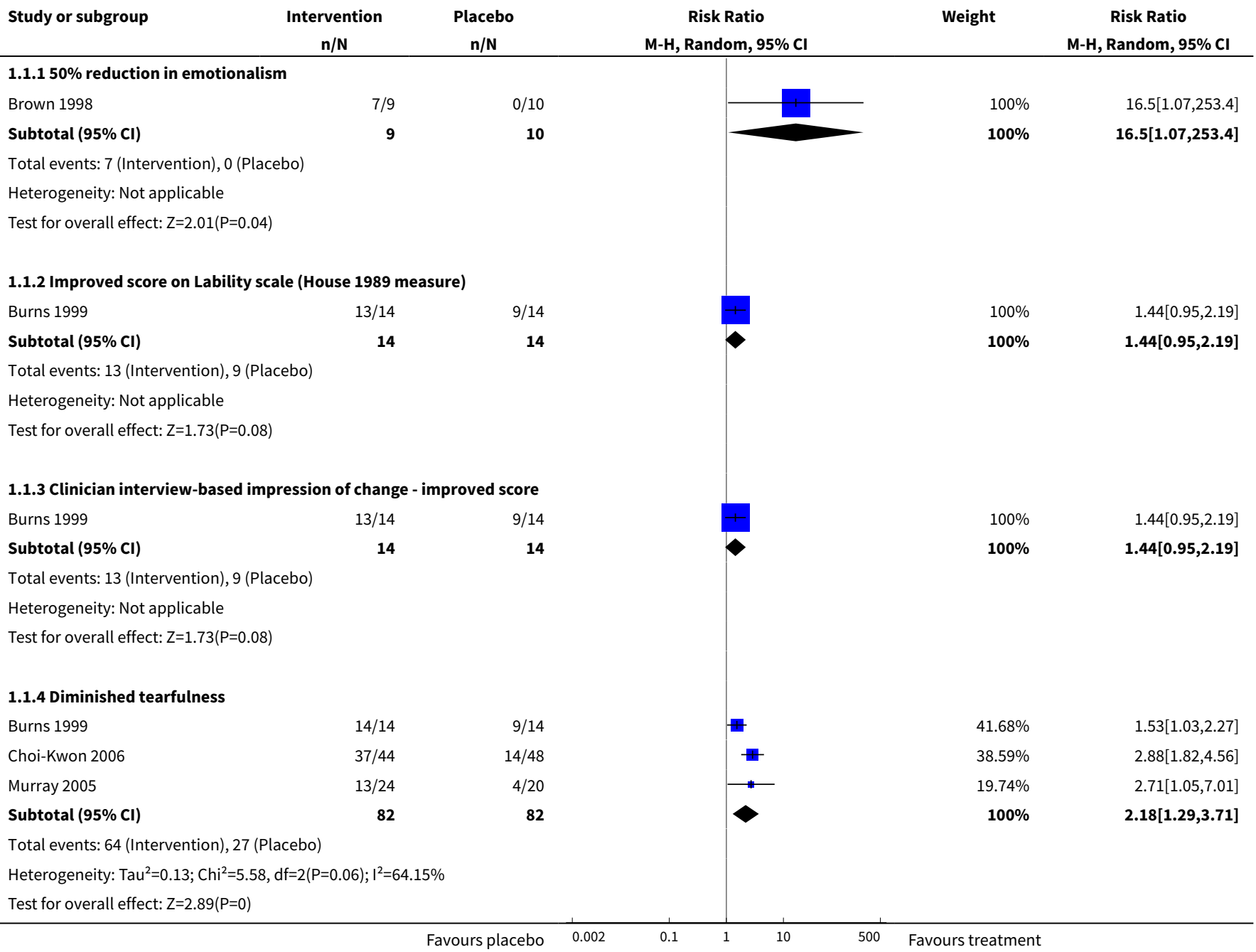

Analysis 1.2. Comparison 1 Pharmaceutical interventions versus placebo, Outcome 2 Emotionalism: mean scores at end of treatment.

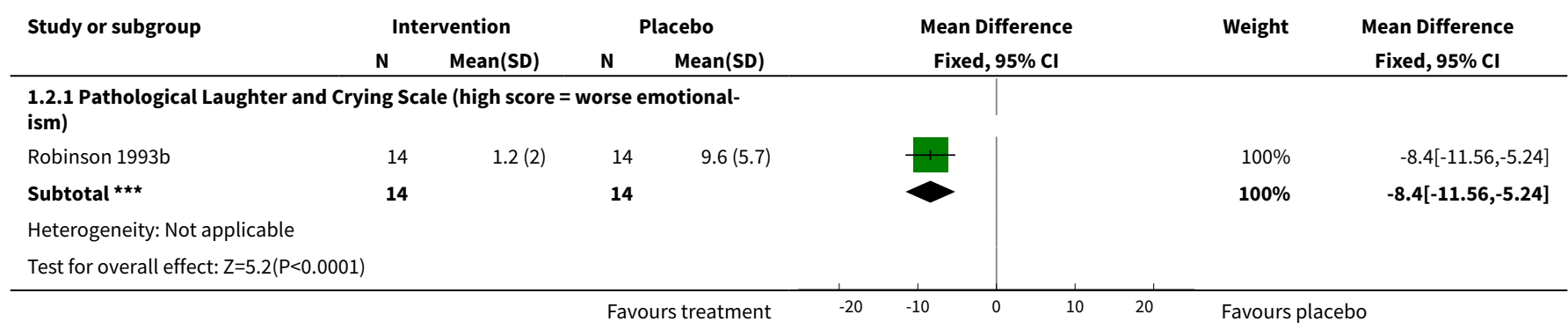


Analysis 1.3. Comparison 1 Pharmaceutical interventions versus placebo, Outcome 3 Depression: 1. Mean scores at end of treatment.

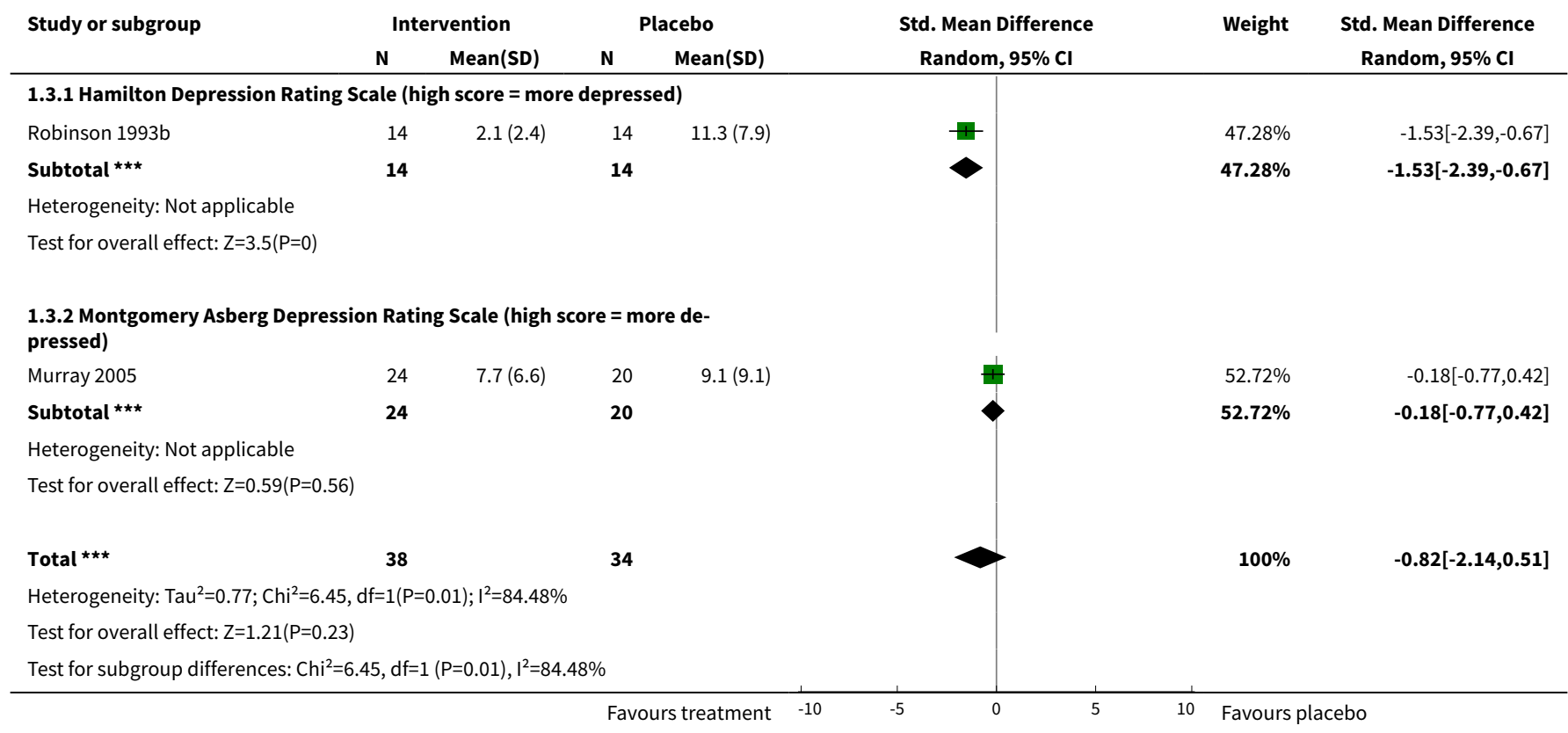

\section{Analysis 1.4. Comparison 1 Pharmaceutical interventions versus placebo, Outcome} 4 Depression: 2. Average change in scores between baseline and end of treatment.

\begin{tabular}{|c|c|c|c|c|c|c|c|}
\hline \multirow[t]{2}{*}{ Study or subgroup } & \multicolumn{2}{|c|}{ Intervention } & \multicolumn{2}{|c|}{ Placebo } & \multirow{2}{*}{$\begin{array}{c}\text { Std. Mean Difference } \\
\text { Random, } 95 \% \mathrm{Cl}\end{array}$} & \multirow[t]{2}{*}{ Weight } & \multirow{2}{*}{$\begin{array}{c}\text { Std. Mean Difference } \\
\text { Random, } 95 \% \mathrm{Cl}\end{array}$} \\
\hline & $\mathbf{N}$ & Mean(SD) & $\mathbf{N}$ & $\operatorname{Mean}($ SD) & & & \\
\hline \multicolumn{8}{|c|}{ 1.4.1 Hamilton Depression Rating Scale (high score = more depressed) } \\
\hline Robinson 1993b & 14 & $-10(5.4)$ & 14 & $-7.3(6.7)$ & \# & $44.28 \%$ & $-0.43[-1.18,0.32]$ \\
\hline Subtotal *** & 14 & & 14 & & & $44.28 \%$ & $-0.43[-1.18,0.32]$ \\
\hline \multicolumn{8}{|c|}{ Heterogeneity: Not applicable } \\
\hline \multicolumn{8}{|c|}{ Test for overall effect: $Z=1.12(P=0.26)$} \\
\hline \multicolumn{8}{|c|}{$\begin{array}{l}\text { 1.4.2 Montgomery Asberg Depression Rating Scale (high score = more de- } \\
\text { pressed) }\end{array}$} \\
\hline Murray 2005 & 24 & $-10.7(6.3)$ & 20 & $-12.6(8.2)$ & & $55.72 \%$ & $0.26[-0.34,0.85]$ \\
\hline Subtotal *** & 24 & & 20 & & & $55.72 \%$ & $0.26[-0.34,0.85]$ \\
\hline \multicolumn{8}{|c|}{ Heterogeneity: Not applicable } \\
\hline \multicolumn{8}{|c|}{ Test for overall effect: $Z=0.85(P=0.4)$} \\
\hline Total $* \star \star$ & 38 & & 34 & & & $100 \%$ & $-0.05[-0.72,0.62]$ \\
\hline \multicolumn{8}{|c|}{ Heterogeneity: $\mathrm{Tau}^{2}=0.12 ; \mathrm{Chi}^{2}=1.98, \mathrm{df}=1(\mathrm{P}=0.16) ; \mathrm{I}^{2}=49.51 \%$} \\
\hline \multicolumn{8}{|c|}{ Test for overall effect: $Z=0.14(P=0.89)$} \\
\hline Test for subgroup dif & $98, \mathrm{df}=$ & $P=0.16), I^{2}=4 \subseteq$ & & & & & \\
\hline
\end{tabular}


Analysis 1.5. Comparison 1 Pharmaceutical interventions versus placebo, Outcome 5 Cognitive functioning: mean scores at end of treatment.

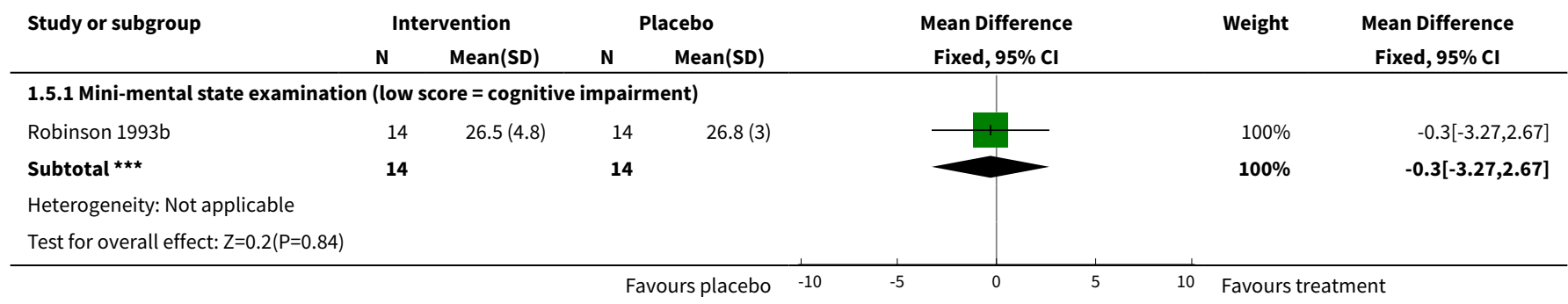

Analysis 1.6. Comparison 1 Pharmaceutical interventions versus placebo, Outcome 6 Activities of daily living: 1. Mean scores at end of treatment.

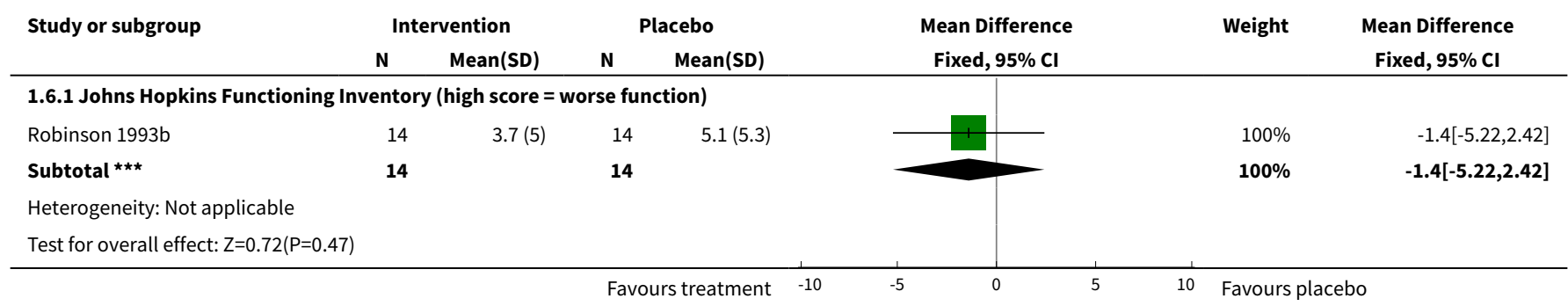

\section{Analysis 1.7. Comparison 1 Pharmaceutical interventions versus placebo, Outcome 7 Adverse events: 1 . Death.}

$\begin{array}{ccccc}\text { Study or subgroup } & \text { Intervention } & \text { Placebo } & \text { Risk Ratio } & \text { Weight } \\ & \mathrm{n} / \mathrm{N} & \mathrm{n} / \mathrm{N} & \mathrm{M}-\mathrm{H}, \text { Random, } 95 \% \mathrm{Cl} & \mathrm{M}-\mathrm{H}, \mathrm{Random}, 95 \% \mathrm{Cl}\end{array}$

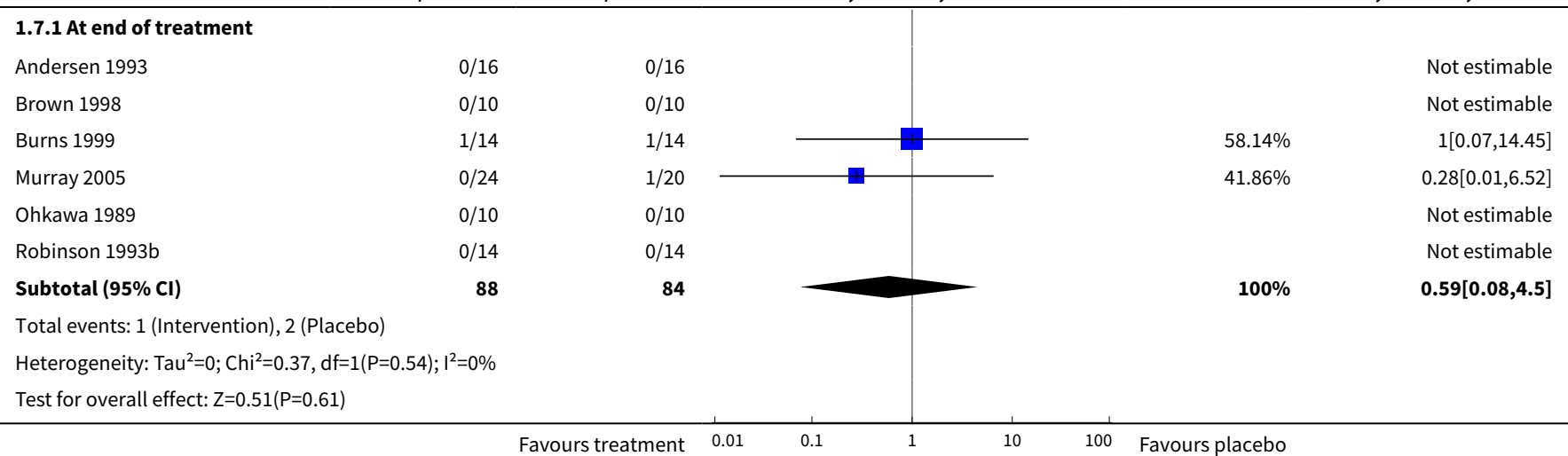

Analysis 1.8. Comparison 1 Pharmaceutical interventions versus placebo, Outcome 8 Adverse events: 2 . All.

\begin{tabular}{|c|c|c|c|c|c|c|c|}
\hline Study or subgroup & $\begin{array}{l}\text { Intervention } \\
n / \mathbf{N}\end{array}$ & $\begin{array}{c}\text { Placebo } \\
n / N\end{array}$ & \multicolumn{2}{|r|}{$\begin{array}{c}\text { Risk Ratio } \\
\text { M-H, Random, } 95 \% \text { CI }\end{array}$} & & Weight & \multirow[t]{2}{*}{$\begin{array}{c}\text { Risk Ratio } \\
\text { M-H, Random, } 95 \% \text { Cl }\end{array}$} \\
\hline \multicolumn{7}{|c|}{ 1.8.1 Central nervous system events (e.g. confusion, sedation, tremor) } & \\
\hline Burns 1999 & $0 / 14$ & $1 / 14$ & & + & & $50 \%$ & $0.33[0.01,7.55]$ \\
\hline
\end{tabular}




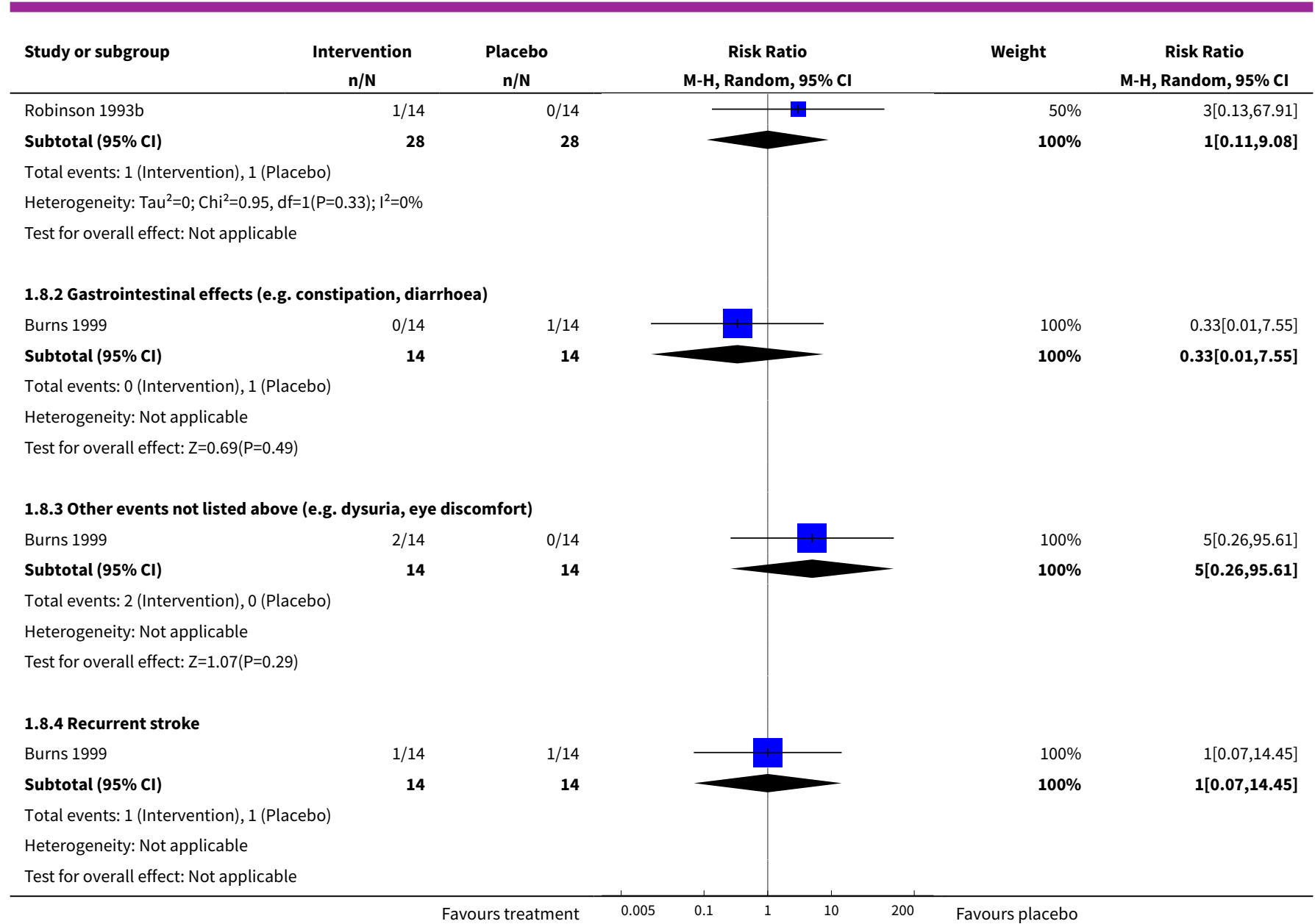

Analysis 1.9. Comparison 1 Pharmaceutical interventions versus placebo, Outcome 9 Adverse events: 3. Leaving the study early (including death).

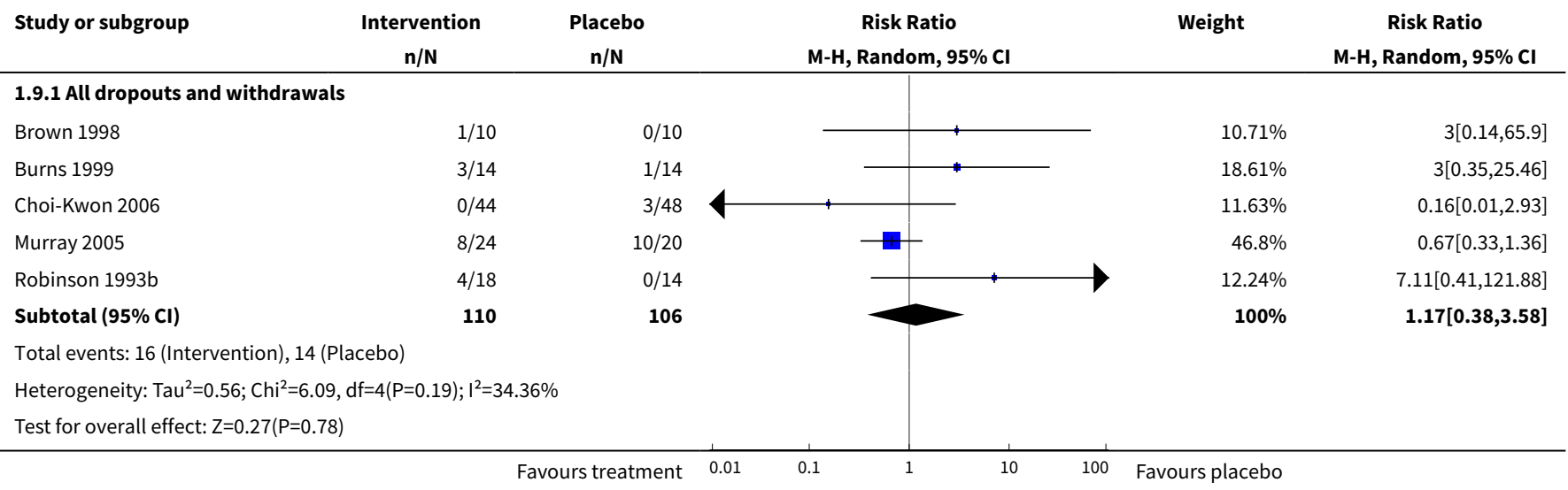

\section{ADDITIONAL TABLES}


Table 1. Characteristics of 'dropout' studies

\begin{tabular}{|c|c|c|c|c|c|}
\hline Study ID & Methods & Participants & $\begin{array}{l}\text { Interven- } \\
\text { tions }\end{array}$ & Outcomes & Notes \\
\hline $\begin{array}{l}\text { Aizawa } \\
1977\end{array}$ & $\begin{array}{l}\text { Study design: } \\
\text { randomised, } \\
\text { parallel design } \\
\text { Number of } \\
\text { arms: } 2 \\
\text { Arm 1: cyclan- } \\
\text { delate } 900 \mathrm{mg} / \\
\text { day + cinnar- } \\
\text { izine } 75 \mathrm{mg} / \text { day } \\
\text { Arm 2: placebo } \\
+ \text { cinnarizine } 75 \\
\text { mg/day } \\
\text { Analysis: per } \\
\text { protocol }\end{array}$ & $\begin{array}{l}\text { Georgraphical location: Japan } \\
\text { Setting: } 50 \text { institutes across South } \\
\text { Korea } \\
\text { Number of participants: } 378 \\
\text { Diagnosis: stroke over one month ago } \\
\text { Inclusion criteria: } 1 \text { ) inpatients and } \\
\text { outpatients who had cerebral infarct, } \\
\text { intracranial bleeding, transient cere- } \\
\text { bral ischaemia and cerebral arte- } \\
\text { riosclerosis } \\
\text { Exclusion criteria: } 1 \text { ) expectant moth- } \\
\text { ers; } 2 \text { ) with glaucoma and 3) severe } \\
\text { concomitant diseases } \\
\text { Age: overall mean age not reported } \\
\text { Numbers included in Arm 1: } 188 \text { (68\% } \\
\text { men, age details unclear) } \\
\text { Numbers included in Arm 2: } 190 \text { (68\% } \\
\text { men, age details unclear) }\end{array}$ & $\begin{array}{l}\text { Arm 1: cy- } \\
\text { clandelate } \\
900 \mathrm{mg} / \text { day } \\
\text { and cin- } \\
\text { narizine } 75 \\
\mathrm{mg} / \text { day } \\
\text { Arm 2: } \\
\text { matched } \\
\text { placebo } \\
\text { and cin- } \\
\text { narizine } 75 \\
\text { mg/day } \\
\text { Duration: } \\
\text { treatment } \\
\text { continued } \\
\text { for } 4 \text { weeks }\end{array}$ & $\begin{array}{l}\text { - Global im- } \\
\text { provement } \\
\text { rating } \\
\text { - Improvement } \\
\text { rating of sub- } \\
\text { jective symp- } \\
\text { toms } \\
\text { - Improvement } \\
\text { rating of psy- } \\
\text { chiatric symp- } \\
\text { toms } \\
\text { - Improvement } \\
\text { rating of neu- } \\
\text { rological } \\
\text { symptoms } \\
\text { - Global utility } \\
\text { rating } \\
\text { - Overall safety } \\
\text { rating }\end{array}$ & $\begin{array}{l}\text { Unable } \\
\text { to use: all } \\
\text { data (da- } \\
\text { ta not pre- } \\
\text { sented by } \\
\text { 'emotion- } \\
\text { alism at } \\
\text { baseline', } \\
\text { unable to } \\
\text { exclude } \\
\text { people } \\
\text { with cere- } \\
\text { bral arte- } \\
\text { rioscle- } \\
\text { rosis and } \\
\text { transient } \\
\text { ischaemic } \\
\text { attack) }\end{array}$ \\
\hline $\begin{array}{l}\text { Ohtomo } \\
1985\end{array}$ & $\begin{array}{l}\text { Study design: } \\
\text { randomised, } \\
\text { parallel design } \\
\text { Number of } \\
\text { arms: } 2 \\
\text { Arm 1: tiapride } \\
75 \mathrm{mg} / \text { day for } 1 \\
\text { week, dose es- } \\
\text { calation to } 150 \\
\text { to } 225 \mathrm{mg} / \text { day } \\
\text { for } 5 \text { weeks ac- } \\
\text { cording to clini- } \\
\text { cal response } \\
\text { Arm 2: placebo } \\
+ \text { cinnarizine } 75 \\
\text { mg/day } \\
\text { Analysis: per } \\
\text { protocol }\end{array}$ & $\begin{array}{l}\text { Geographical location: Japan } \\
\text { Setting: unclear } \\
\text { Number of participants: } 188 \\
\text { Diagnosis: cerebral haemorrhage, } \\
\text { subarachnoid haemorrhage, cerebral } \\
\text { infarction, cerebral apoplexy seque- } \\
\text { lae, cerebral arteriosclerosis } \\
\text { Inclusion criteria: } 1 \text { ) patients with } \\
\text { cerebral arteriosclerosis } \\
\text { Exclusion criteria: 1) severe aphasia, } \\
\text { 2) severe dementia, 3) drug depen- } \\
\text { dence, } 4 \text { ) inadequate conditions for } \\
\text { the study } \\
\text { Age: overall mean age not reported } \\
\text { Numbers included in Arm 1: } 141 \text { (54\% } \\
\text { men, age details unclear) } \\
\text { Numbers included in Arm 2: } 147 \text { (61\% } \\
\text { men, age details unclear) }\end{array}$ & $\begin{array}{l}\text { Arm 1: } \\
\text { tiapride } \\
75 \mathrm{mg} / \text { day } \\
\text { for } 1 \text { week, } \\
\text { dose esca- } \\
\text { lation to } \\
150 \text { to } 225 \\
\mathrm{mg} / \text { day for } \\
5 \text { weeks ac- } \\
\text { cording to } \\
\text { clinical re- } \\
\text { sponse } \\
\text { Arm 2: } \\
\text { matched } \\
\text { placebo } \\
\text { Duration: } \\
\text { treatment } \\
\text { continued } \\
\text { for } 6 \text { weeks }\end{array}$ & $\begin{array}{l}\text { - Severity of } \\
\text { psychiatric } \\
\text { symptoms } \\
\text { - Activities of } \\
\text { daily living } \\
\text { - Somatic com- } \\
\text { plaints }\end{array}$ & $\begin{array}{l}\text { Unable } \\
\text { to use: all } \\
\text { data (da- } \\
\text { ta not pre- } \\
\text { sented by } \\
\text { 'emotion- } \\
\text { alism at } \\
\text { baseline', } \\
\text { unable to } \\
\text { exclude } \\
\text { people } \\
\text { with cere- } \\
\text { bral arte- } \\
\text { riosclero- } \\
\text { sis) }\end{array}$ \\
\hline Kim 2017a & $\begin{array}{l}\text { Study design: } \\
\text { randomised, } \\
\text { parallel design } \\
\text { Number of } \\
\text { arms: } 2\end{array}$ & $\begin{array}{l}\text { Geographical location: South Korea } \\
\text { Setting: } 17 \text { hospitals across South Ko- } \\
\text { rea } \\
\text { Number of participants: } 478\end{array}$ & $\begin{array}{l}\text { Arm 1: esc- } \\
\text { italopram } \\
10 \mathrm{mg} / \text { day } \\
\text { Arm 2: } \\
\text { matched } \\
\text { placebo }\end{array}$ & $\begin{array}{l}\text { Primary out- } \\
\text { comes: } \\
\text { - occurrence of } \\
\text { moderate or } \\
\text { severe de- }\end{array}$ & $\begin{array}{l}\text { Unable } \\
\text { to use: } \\
\text { all data } \\
\text { (data pre- } \\
\text { sented by } \\
\text { 'emotion- }\end{array}$ \\
\hline
\end{tabular}


Table 1. Characteristics of 'dropout' studies (Continued)

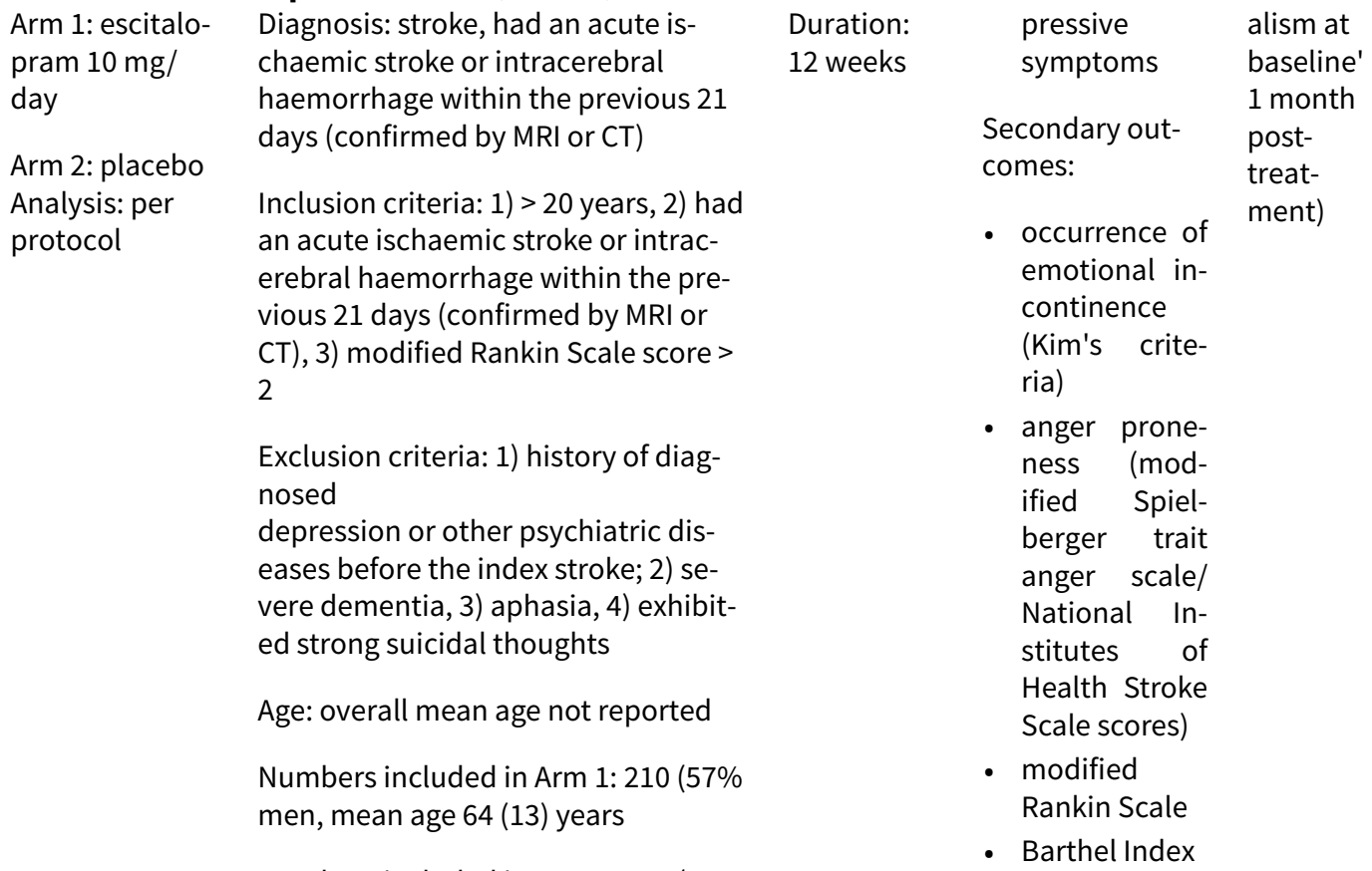

Numbers included in Arm 2: 195 (65\%

- Barthel Index

CT: computerised tomography

MRI: magnetic resonance imaging

\section{APPEN DICES}

\section{Appendix 1. 2008 search strategy}

\section{Electronic searches}

Cochrane Stroke and Cochrane Anxiety and Neurosis trial registers- searched on August 2009.

The remaining databases were searched on May 2008:

1. Cochrane Central Register for Controlled Trials

2. MEDLINE

3. Embase

4. CINAHL

5. Psycinfo

6. Applied Science and Technology Plus

7. Arts and Humanities Index

8. Biological Abstracts

9. BIOSIS Previews

10.General Science Plus

11.Science Citation Index

12.Social Science Citation Index

13.Sociological Abstract/SocioFile

14.ISI Web of Science

15.Dissertations and Theses

The following search strategy with a combination of controlled vocabulary and free test terms for MEDLINE (Ovid) was used and adapted it for the other databases.

Pharmaceutical interventions for emotionalism after stroke (Review) 
1. cerebrovascular disorders/ or exp basal ganglia cerebrovascular disease/ or exp brain ischemia/ or exp carotid artery diseases/ or exp intracranial arterial diseases/ or exp "intracranial embolism and thrombosis"/ or exp intracranial hemorrhages/ or stroke/ or exp brain infarction/ or vasospasm, intracranial/ or vertebral artery dissection/

2. (stroke or poststroke or post-stroke or cerebrovasc $\$$ or brain vasc $\$$ or cerebral vasc\$ or cva\$ or apoplex\$ or SAH).tw.

3. ((brain $\$$ or cerebr\$ or cerebell\$ or intracran\$ or intracerebral) adj5 (isch?emi\$ or infarct\$ or thrombo $\$$ or emboli\$ or occlus\$)).tw.

4. ((brain $\$$ or cerebr $\$$ or cerebell\$ or intracerebral or intracranial or subarachnoid) adj5 (haemorrhage $\$$ or hemorrhage $\$$ or haematoma

$\$$ or hematoma $\$$ or bleed\$)).tw.

5. 1 or 2 or 3 or 4

6. crying/ or laughter/

7. affective symptoms/ or emotions/

8. (laugh\$ or cry\$ or weep or weeping or emotional\$ or pseudobulbar affect).tw.

9. 6 or 7 or 8

10. Randomized Controlled Trials as Topic/

11. random allocation/

12. Controlled Clinical Trials as Topic/

13. control groups/

14. clinical trials as topic/ or clinical trials, phase i as topic/ or clinical trials, phase ii as topic/ or clinical trials, phase iii as topic/ or clinical trials, phase iv as topic/

15. double-blind method/

16. single-blind method/

17. Placebos/

18. placebo effect/

19. cross-over studies/

20. Multicenter Studies as Topic/

21. Therapies, Investigational/

22. Drug Evaluation/

23. Research Design/

24. Program Evaluation/

25. evaluation studies as topic/

26. randomized controlled trial.pt.

27. controlled clinical trial.pt.

28. (clinical trial or clinical trial phase i or clinical trial phase ii or clinical trial phase iii or clinical trial phase iv).pt.

29. multicenter study.pt.

30. (evaluation studies or comparative study).pt.

31. meta analysis.pt.

32. meta-analysis as topic/

33. random\$.tw.

34. (controlled adj5 (trial\$ or stud\$)).tw.

35. (clinical\$ adj5 trial\$).tw.

36. ((control or treatment or experiment $\$$ or intervention) adj5 (group\$ or subject\$ or patient\$)).tw.

37. (quasi-random\$ or quasi random\$ or pseudo-random\$ or pseudo random\$).tw.

38. ((multicenter or multicentre or therapeutic) adj5 (trial\$ or stud\$)).tw.

39. ((control or experiment $\$$ or conservative) adj5 (treatment or therapy or procedure or manage\$)).tw.

40. ((singl\$ or doubl\$ or tripl\$ or trebl\$) adj5 (blind\$ or mask\$)).tw.

41. (coin adj5 (flip or flipped or toss\$)).tw.

42. latin square.tw.

43. versus.tw.

44. (cross-over or cross over or crossover).tw.

45. placebo\$.tw.

46. sham.tw.

47. (assign\$ or alternate or allocat\$ or counterbalance\$ or multiple baseline).tw.

48. controls.tw.

49. (treatment\$ adj6 order).tw.

50. (meta-analy\$ or metaanaly\$ or meta analy\$ or systematic review or systematic overview).tw.

51. or/10-50

52. 5 and 9 and 51

53. limit 52 to humans

54. limit 53 to $y r=" 2002-2008$ "

\section{Additional searches}

We searched the following conference abstracts and proceedings: 
- European Stroke Conferences (2000 to 2008);

- Stroke Society of Australasia Annual Scientific Meetings (1999 to 2008).

We also searched online clinical trials and research registers in May 2008:

- www.strokecenter.org/trials;

- www.ClinicalTrials.gov;

- www.Clinicalstudyresults.org;

- www.anzctr.org.au.

\section{Reference lists}

Reference lists of relevant studies were searched to identify studies not already included.

\section{Personal communication}

Professional bodies, authors of included studies and pharmaceutical companies were contacted for information on published and unpublished information.

\section{Appendix 2. CENTRAL}

\begin{tabular}{ll}
\hline ID & Search \\
\hline$\# 1$ & [mh^"cerebrovascular disorders"] or [mh "basal ganglia cerebrovascular disease"] or [mh "brain \\
& ischemia"] or [mh "carotid artery diseases"] or [mh "intracranial arterial diseases"] or [mh "in- \\
& tracranial arteriovenous malformations"] or [mh "intracranial embolism and thrombosis"] or [mh \\
& "intracranial hemorrhages"] or [mh ^stroke] or [mh "brain infarction"] or [mh^"stroke, lacunar"] or \\
& {$\left[\mathrm{mh}^{\wedge}\right.$ "vasospasm, intracranial"] or [mh ${ }^{\wedge}$ "vertebral artery dissection"] or [mh ${ }^{\wedge}$ "brain injuries"] or } \\
& {$\left[\mathrm{mh}^{\wedge}\right.$ "brain injury, chronic"] } \\
\hline
\end{tabular}

\#2 (stroke or poststroke or post-stroke or cerebrovasc ${ }^{\star}$ or brain next vasc ${ }^{\star}$ or cerebral next vasc ${ }^{\star}$ or
cva* or apoplex $^{*}$ or SAH):ti,ab,kw (Word variations have been searched)

\#3 ((brain ${ }^{\star}$ or cerebr ${ }^{\star}$ or cerebell ${ }^{\star}$ or intracran ${ }^{\star}$ or intracerebral) near/5 (isch $^{\star}$ emi $^{\star}$ or infarct $^{\star}$ or thrombo* or emboli* or occlus*)):ti,ab,kw (Word variations have been searched)

\#4

((brain ${ }^{\star}$ or cerebr ${ }^{\star}$ or cerebell* or intracerebral or intracranial or subarachnoid) near/5 (haemorrhage* or hemorrhage* or haematoma* or hematoma* or bleed*)):ti,ab,kw (Word variations have been searched)

\begin{tabular}{ll}
\hline$\# 5$ & $\{$ or \#1-\#4\} \\
\hline$\# 6$ & {$[\mathrm{mh} \wedge$ crying] or [mh ^laughter] } \\
\hline$\# 7$ & {$\left[\mathrm{mh}^{\wedge}\right.$ "affective symptoms"] or [mh ^emotions] } \\
\hline$\# 8$ & $\begin{array}{l}\text { emotion* or laugh* or cry }{ }^{\star} \text { or weep* or tearful }{ }^{\star} \text { or pseudobulbar affect:ti,ab,kw (Word variations } \\
\text { have been searched) }\end{array}$ \\
\hline$\# 9$ & $\{$ or \#6-\#8\} \\
\hline$\# 5$ and \#9 Publication Year from 2008 to 2018 \\
\hline
\end{tabular}

\section{Search results: 106}




\section{Appendix 3. MEDLINE}

\section{Search strategy for MEDLINE, May 2018}

1. cerebrovascular disorders/ or exp basal ganglia cerebrovascular disease/ or exp brain ischemia/ or exp carotid artery diseases/or exp intracranial arterial diseases/ or exp "intracranial embolism and thrombosis"/ or exp intracranial hemorrhages/ or stroke/ or exp brain infarction/ or vasospasm, intracranial/ or vertebral artery dissection/

2. (stroke or poststroke or post-stroke or cerebrovasc $\$$ or brain vasc $\$$ or cerebral vasc $\$$ or cva $\$$ or apoplex\$ or SAH).tw.

3. ((brain\$ or cerebr\$ or cerebell\$ or intracran\$ or intracerebral) adj5 (isch?emi\$ or infarct\$ or thrombo $\$$ or emboli\$ or occlus\$)).tw.

4. ((brain\$ or cerebr\$ or cerebell\$ or intracerebral or intracranial or subarachnoid) adj5 (haemorrhage or hemorrhage $\$$ or haematoma \$ or hematoma\$ or bleed\$)).tw.

5.1 or 2 or 3 or 4

6. crying/ or laughter/

7. affective symptoms/ or exp emotions/

8. (laugh\$ or cry\$ or weep\$ or emotional\$ or pseudobulbar affect).tw.

9. 6 or 7 or 8

10. Randomized Controlled Trials as Topic/

11. random allocation/

12. Controlled Clinical Trials as Topic/

13. control groups/

14. clinical trials as topic/ or clinical trials, phase i as topic/ or clinical trials, phase ii as topic/ or clinical trials, phase iii as topic/ or clinical trials, phase iv as topic/

15. double-blind method/

16. single-blind method/

17. Placebos/

18. placebo effect/

19. cross-over studies/

20. randomized controlled trial.pt.

21. controlled clinical trial.pt.

22. (clinical trial or clinical trial phase i or clinical trial phase ii or clinical trial phase iii or clinical trial phase iv).pt.

23. (random\$ or RCT or RCTs).tw.

24. (controlled adj5 (trial\$ or stud\$)).tw.

25. (clinical\$ adj5 trial\$).tw.

26. ((control or treatment or experiment\$ or intervention) adj5 (group\$ or subject\$ or patient\$)).tw.

27. (quasi-random $\$$ or quasi random\$ or pseudo-random $\$$ or pseudo random\$).tw.

28. ((control or experiment $\$$ or conservative) adj5 (treatment or therapy or procedure or manage $\$)$ ).tw.

29. ((singl\$ or doubl\$ or tripl\$ or trebl\$) adj5 (blind\$ or mask\$)).tw.

30. (cross-over or cross over or crossover).tw.

31. (placebo\$ or sham).tw.

32. trial.ti.

33. (assign\$ or allocat\$).tw.

34. controls.tw.

35. or $/ 10-34$

36. exp animals/ not humans.sh.

37.5 and 9 and 35

38. 37 not 36

\section{Search results: 179}

\section{Appendix 4. Embase}

\section{Search strategy for Embase, May 2018}

1. cerebrovascular disease/ or brain disease/ or exp basal ganglion hemorrhage/ or exp brain hemangioma/ or exp brain hematoma/ or exp brain hemorrhage/ or exp brain infarction/ or exp brain ischemia/ or exp carotid artery disease/ or exp cerebral artery disease/ or exp cerebrovascular accident/ or exp cerebrovascular malformation/ or exp intracranial aneurysm/ or exp occlusive cerebrovascular disease/ or exp vertebrobasilar insufficiency/

2. (stroke $\$$ or poststroke or apoplex\$ or cerebral vasc\$ or brain vasc\$ or cerebrovasc\$ or cva\$ or SAH).tw.

3. ( (brain or cerebr $\$$ or cerebell\$ or vertebrobasil\$ or hemispher $\$$ or intracran $\$$ or intracerebral or infratentorial or supratentorial or middle cerebral artery or MCA $\$$ or anterior circulation or posterior circulation or basilar artery or vertebral artery or space-occupying) adj5 (isch? emi\$ or infarct\$ or thrombo\$ or emboli\$ or occlus\$ or hypoxi\$)).tw.

4. ((brain\$ or cerebr\$ or cerebell\$ or intracerebral or intracran\$ or parenchymal or intraparenchymal or intraventricular or infratentorial or supratentorial or basal gangli\$ or putaminal or putamen or posterior fossa or hemispher\$ or subarachnoid) adj5 (h?emorrhag\$ or h? ematoma\$ or bleed\$)).tw. 
5.1 or 2 or 3 or 4

6. crying/ or pathological crying/ or laughter/ or pathological laughter/ or nonverbal communication/

7. emotion/ or affective neurosis/

8. emotional stability/ or emotionality/

9. (emotion\$ or laugh\$ or cry\$ or weep\$ or tearful\$ or pseudobulbar affect).tw.

10.6 or 7 or 8 or 9

11. Randomized Controlled Trial/ or "randomized controlled trial (topic)"/

12. Randomization/

13. Controlled clinical trial/ or "controlled clinical trial (topic)"/

14. control group/ or controlled study/

15. clinical trial/ or "clinical trial (topic)"/ or phase 1 clinical trial/ or phase 2 clinical trial/ or phase $3 \mathrm{clinical}$ trial/ or phase $4 \mathrm{clinical}$ trial/

16. Crossover Procedure/

17. Double Blind Procedure/

18. Single Blind Procedure/ or triple blind procedure/

19. placebo/ or placebo effect/

20. (random $\$$ or RCT or RCTs).tw.

21. (controlled adj5 (trial\$ or stud\$)).tw.

22. (clinical\$ adj5 trial\$).tw.

23. ((control or treatment or experiment\$ or intervention) adj5 (group\$ or subject\$ or patient\$)).tw.

24. (quasi-random $\$$ or quasi random $\$$ or pseudo-random $\$$ or pseudo random\$).tw.

25. ((control or experiment\$ or conservative) adj5 (treatment or therapy or procedure or manage\$)).tw.

26. ((singl\$ or doubl\$ or tripl\$ or trebl\$) adj5 (blind\$ or mask\$)).tw.

27. (cross-over or cross over or crossover).tw.

28. (placebo $\$$ or sham).tw.

29. trial.ti.

30. (assign\$ or allocat\$).tw.

31. controls.tw.

32. or $/ 11-31$

33. (exp animals/or exp invertebrate/ or animal experiment/ or animal model/or animal tissue/ or animal cell/ or nonhuman/) not (human/ or normal human/ or human cell/)

34.5 and 10 and 32

35.34 not 33

\section{Search results: 644}

\section{Appendix 5. CINAHL}

Search strategy for CINAHL, May 2018

\# Query

S1

(MH "Cerebrovascular Disorders") OR (MH "Basal Ganglia Cerebrovascular Disease+") OR (MH

"Carotid Artery Diseases+") OR (MH "Cerebral Ischemia+") OR (MH "Cerebral Vasospasm") OR (MH

"Intracranial Arterial Diseases+") OR (MH "Intracranial Embolism and Thrombosis") OR (MH "Intracranial Hemorrhage+") OR (MH "Stroke") OR (MH "Vertebral Artery Dissections")

S2 (MH "Stroke Patients") OR (MH "Stroke Units")

\begin{tabular}{|c|c|}
\hline S3 & $\begin{array}{l}\text { TI (stroke* or poststroke or apoplex } \text { or cerebral vasc }^{\star} \text { or brain vasc } \text { or cerebrovasc }^{\star} \text { or cva* }^{\star} \text { or } \\
\text { SAH ) or AB ( } \text { stroke }^{\star} \text { or poststroke or apoplex } \text { or cerebral vasc }^{\star} \text { or brain vasc } \text { or cerebrovasc }^{\star} \text { or } \\
\text { cva }^{\star} \text { or SAH) }\end{array}$ \\
\hline S4 & 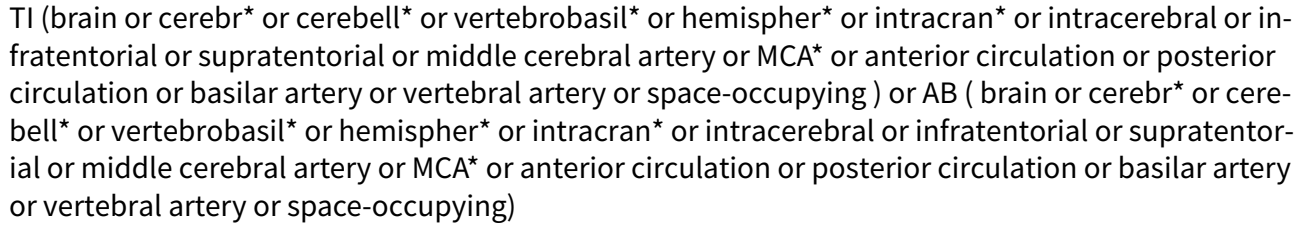 \\
\hline
\end{tabular}




\section{S6}

S7

\section{S4 and S5}

TI (brain* or cerebr* or cerebell* or intracerebral or intracran* or parenchymal or intraparenchymal or intraventricular or infratentorial or supratentorial or basal gangli* or putaminal or putamen or posterior fossa or hemispher ${ }^{\star}$ or subarachnoid) or AB (brain* or cerebr ${ }^{\star}$ or cerebell ${ }^{\star}$ or intracerebral or intracran ${ }^{\star}$ or parenchymal or intraparenchymal or intraventricular or infratentorial or supratentorial or basal gangli* or putaminal or putamen or posterior fossa or hemispher ${ }^{\star}$ or subarachnoid)

TI (haemorrhage* or hemorrhage* or haematoma* or hematoma* or bleed ${ }^{\star}$ ) or AB ( haemorrhage* or hemorrhage* or haematoma* or hematoma* or bleed*)

\begin{tabular}{|c|c|}
\hline S9 & S7 and S8 \\
\hline S10 & S1 OR S2 OR S3 OR S6 OR S9 \\
\hline S11 & (MH "Emotions+") OR (MH "Affective Symptoms+") \\
\hline S12 & (MH "Laughter") OR (MH "Crying") OR (MH "Nonverbal Communication") \\
\hline S13 & $\begin{array}{l}\text { TI ((laugh* or cry* or weep }{ }^{\star} \text { or emotional }{ }^{\star} \text { or pseudobulbar affect) ) OR AB ( (laugh* or cry }{ }^{\star} \text { or } \\
\text { weep }^{\star} \text { or emotional }{ }^{\star} \text { or pseudobulbar affect)) }\end{array}$ \\
\hline S14 & S11 OR S12 OR S13 \\
\hline S15 & (MH "Randomized Controlled Trials") or (MH "Random Assignment") or (MH "Random Sample+") \\
\hline S16 & (MH "Clinical Trials") or (MH "Intervention Trials") or (MH "Therapeutic Trials") \\
\hline S17 & (MH "Control (Research)") or (MH "Control Group") or (MH "Placebos") or (MH "Placebo Effect") \\
\hline S18 & (MH "Crossover Design") OR (MH "Quasi-Experimental Studies") \\
\hline S19 & (MH "Crossover Design") OR (MH "Quasi-Experimental Studies") \\
\hline S20 & PT (clinical trial or randomized controlled trial) \\
\hline S21 & $\mathrm{TI}$ (random* or RCT or RCTs) or AB (random* or RCT or RCTs) \\
\hline S22 & TI (controlled N5 (trial* or stud $\left.\left.{ }^{\star}\right)\right)$ or AB (controlled N5 (trial* or stud $\left.{ }^{\star}\right)$ ) \\
\hline S23 & TI (clinical* N5 trial*) or AB (clinical* N5 trial*) \\
\hline S24 & 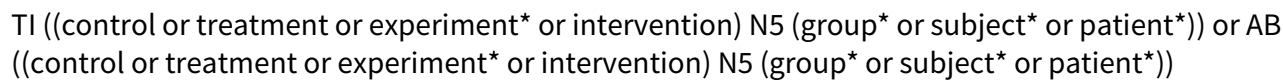 \\
\hline
\end{tabular}

\section{Search results: 148}

\section{Appendix 6. PsycINFO}

\section{Search strategy for PsycINFO, May 2018}

1. cerebrovascular disorders/ or cerebral hemorrhage/ or exp cerebral ischemia/ or cerebral small vessel disease/ or cerebrovascular accidents/ or subarachnoid hemorrhage/ 
2. (stroke\$ or poststroke or apoplex\$ or cerebral vasc\$ or brain vasc\$ or cerebrovasc\$ or cva\$ or SAH).tw.

3. ((brain or cerebr $\$$ or cerebell\$ or vertebrobasil\$ or hemispher $\$$ or intracran $\$$ or intracerebral or infratentorial or supratentorial or middle cerebral artery or MCA\$ or anterior circulation or posterior circulation or basilar artery or vertebral artery or space-occupying) adj5 (isch? emi\$ or infarct\$ or thrombo $\$$ or emboli\$ or occlus\$ or hypoxi\$)).tw.

4. ((brain\$ or cerebr\$ or cerebell\$ or intracerebral or intracran\$ or parenchymal or intraparenchymal or intraventricular or infratentorial or supratentorial or basal gangli\$ or putaminal or putamen or posterior fossa or hemispher\$ or subarachnoid) adj5 (h?emorrhag\$ or h? ematoma\$ or bleed\$)).tw.

5. hemiparesis/ or hemiplegia/

6. (hemipleg\$ or hemipar\$ or paresis or paraparesis or paretic).tw.

7. 1 or 2 or 3 or 4 or 5 or 6

8. exp emotions/ or emotional adjustment/ or emotional stability/ or emotional instability/ or "resilience (psychological)"/ or exp emotional responses/ or "emotionality (personality)"/ or emotional states/or emotional adjustment/ or emotional control/ or emotionally disturbed/

9. "crying/ or laughter/ or nonverbal communication/ or distress/"

10. (emotion\$ or laugh\$ or cry\$ or weep\$ or tearful\$ or pseudobulbar affect).tw.

11. 8 or 9 or 10

12. clinical trials/ or treatment effectiveness evaluation/ or placebo/

13. (random\$ or RCT or RCTs).tw.

14. (controlled adj5 (trial\$ or stud\$)).tw.

15. (clinical\$ adj5 trial\$).tw.

16. ((control or treatment or experiment\$ or intervention) adj5 (group\$ or subject\$ or patient\$)).tw.

17. (quasi-random\$ or quasi random\$ or pseudo-random\$ or pseudo random\$).tw.

18. ((control or experiment\$ or conservative) adj5 (treatment or therapy or procedure or manage $\$)$ ).tw.

19. ((singl\$ or doubl\$ or tripl\$ or trebl\$) adj5 (blind\$ or mask\$)).tw.

20. (cross-over or cross over or crossover).tw.

21. (placebo $\$$ or sham).tw.

22. trial.ti.

23. (assign\$ or allocat\$).tw.

24. controls.tw.

25. or/12-24

26. 7 and 11 and 25

\section{Search results: 54}

\section{Appendix 7. BIOSIS Previews}

\section{Search strategy for BIOSIS, May 2018}

\begin{tabular}{|c|c|}
\hline \# & Query \\
\hline S1 & $\begin{array}{l}\text { TS }=\left(\text { stroke } \text { or poststroke or post-stroke or cerebrovasc }^{\star} \text { or brain vasc }{ }^{\star} \text { or cerebral vasc }{ }^{\star} \text { or cva* or }\right. \\
\text { apoplex }{ }^{\star} \text { or SAH) }\end{array}$ \\
\hline S2 & $\begin{array}{l}\text { TS }=\left(\left(\text { brain }^{\star} \text { or cerebr* or cerebell* or intracran* or intracerebral) NEAR/5 (isch\$emi* or infarct }{ }^{\star} \text { or }\right.\right. \\
\left.\text { thrombo* or emboli* or occlus })^{\star}\right)\end{array}$ \\
\hline S3 & $\begin{array}{l}\mathrm{TS}=\left(\left(\text { brain }^{\star} \text { or cerebr* or cerebell* or intracerebral or intracranial or subarachnoid) NEAR/5 (haem- }\right.\right. \\
\left.\left.\text { orrhage }^{\star} \text { or hemorrhage* or haematoma* or hematoma* or bleed }{ }^{\star}\right)\right)\end{array}$ \\
\hline S4 & \#3 OR \#2 OR \#1 \\
\hline S5 & TS $=\left(\right.$ emotion $^{\star}$ or laugh ${ }^{\star}$ or cry $^{\star}$ or weep ${ }^{\star}$ or tearful ${ }^{\star}$ or pseudobulbar affect $)$ \\
\hline S6 & $\mathrm{TS}=\left(\right.$ random ${ }^{*}$ or RCT or RCTs) \\
\hline S7 & $\mathrm{TS}=\left(\right.$ controlled NEAR/5 $\left(\right.$ trial $^{\star}$ or stud $\left.\left.{ }^{\star}\right)\right)$ \\
\hline S8 & $\mathrm{TS}=\left(\right.$ clinical $^{\star} \mathrm{NEAR} / 5$ trial $\left.^{\star}\right)$ \\
\hline
\end{tabular}




\begin{tabular}{|c|c|}
\hline s9 & $\mathrm{TS}=\left(\left(\right.\right.$ control or treatment or experiment ${ }^{\star}$ or intervention) NEAR/5 (group ${ }^{\star}$ or subject ${ }^{\star}$ or patient $\left.\left.t^{\star}\right)\right)$ \\
\hline S10 & $\mathrm{TS}=($ quasi-random* or quasi random or pseudo-random or pseudo random*) \\
\hline S11 & $\begin{array}{l}\text { TS }=\left(\left(\text { control or experiment }{ }^{\star} \text { or conservative) NEAR/5 (treatment or therapy or procedure or man- }\right.\right. \\
\left.\left.\text { age }^{\star}\right)\right)\end{array}$ \\
\hline S12 & TS $=\left(\left(\right.\right.$ singl $l^{\star}$ or doubl ${ }^{\star}$ or tripl $l^{\star}$ or trebl*) NEAR/5 $\left.\left.\left(\text { blind }^{\star} \text { or mask }\right)^{\star}\right)\right)$ \\
\hline S13 & $\mathrm{TS}=$ (cross-over or cross over or crossover) \\
\hline S14 & $\mathrm{TS}=\left(\right.$ placebo ${ }^{\star}$ or sham) \\
\hline S15 & TS=trial \\
\hline S16 & $\mathrm{TS}=\left(\right.$ assign $^{\star}$ or allocat $\left.^{\star}\right)$ \\
\hline S17 & $\mathrm{TS}=$ controls \\
\hline S18 & \#17 OR \#16 OR \#15 OR \#14 OR \#13 OR \#12 OR \#11 OR \#10 OR \#9 OR \#8 OR \#7 OR \#6 \\
\hline S19 & \#18 AND \#5 AND \#4 \\
\hline
\end{tabular}

\section{Search results: 757}

\section{Appendix 8. Web of Science}

\section{Search strategy for Web of Science, May 2018}

The following indexes Science Citation Index Expanded (SCI-EXPANDED), Social Sciences Citation Index (SSCI), and Arts \& Humanities Citation Index (A\&HCl) within Web of Science were searched from January 2002 to May 2018.

\begin{tabular}{|c|c|}
\hline \# & Query \\
\hline 1 & $\begin{array}{l}\text { TS=(stroke or poststroke or post-stroke or cerebrovasc }{ }^{\star} \text { or brain vasc }{ }^{\star} \text { or cerebral vasc }{ }^{\star} \text { or } \text { cva }^{*} \text { or } \\
\text { apoplex* or SAH) } \\
\text { Indexes }=\text { SCI-EXPANDED, SSCI, A\&HCI Timespan }=2002-2018\end{array}$ \\
\hline 2 & $\begin{array}{l}\text { TS }=\left(\left(\text { brain }^{\star} \text { or cerebr* or cerebell* or intracran }{ }^{\star} \text { or intracerebral) NEAR/5 (isch\$emi* or infarct }{ }^{\star} \text { or }\right.\right. \\
\left.\left.\text { thrombo } \text { or emboli* or occlus }^{\star}\right)\right) \\
\text { Indexes=SCI-EXPANDED, SSCI, A\&HCI Timespan }=2002-2018\end{array}$ \\
\hline 3 & $\begin{array}{l}\text { TS }=\left(\left(\text { brain }^{*} \text { or cerebr* or cerebell* or intracerebral or intracranial or subarachnoid) NEAR/5 (h?em- }\right.\right. \\
\left.\left.\text { orrhage* or haematoma* or hematoma* or bleed }{ }^{\star}\right)\right) \\
\text { Indexes=SCI-EXPANDED, SSCI, A\&HCI Timespan }=2002-2018\end{array}$ \\
\hline 4 & $\begin{array}{l}\# 3 \text { OR \#2 OR \#1 } \\
\text { Indexes=SCI-EXPANDED, SSCl, A\&HCI Timespan=2002-2018 }\end{array}$ \\
\hline 5 & 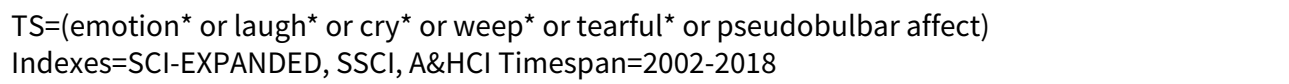 \\
\hline 6 & $\begin{array}{l}\text { TS }=\left(\text { random }{ }^{*} \text { or RCT or RCTs) }\right. \\
\text { Indexes }=S C I-E X P A N D E D, S S C I, A \& H C I \text { Timespan=2002-2018 }\end{array}$ \\
\hline
\end{tabular}


$\mathrm{TS}=\left(\right.$ controlled NEAR/5 $\left(\right.$ trial $^{*}$ or stud $\left.\left.^{\star}\right)\right)$

Indexes=SCI-EXPANDED, SSCI, A\&HCI Timespan=2002-2018

\begin{tabular}{|c|c|}
\hline 8 & $\begin{array}{l}\left.\text { TS=(clinical* NEAR/5 trial }{ }^{\star}\right) \\
\text { Indexes=SCI-EXPANDED, SSCI, A\&HCI Timespan=2002-2018 }\end{array}$ \\
\hline 9 & $\begin{array}{l}\text { TS }=\left(\left(\text { control or treatment or experiment }{ }^{\star} \text { or intervention) NEAR/5 (group }{ }^{\star} \text { or subject }{ }^{\star} \text { or patient }{ }^{\star}\right)\right) \\
\text { Indexes }=S C I-E X P A N D E D, S S C I, A \& H C I \text { Timespan }=2002-2018\end{array}$ \\
\hline 10 & $\begin{array}{l}\text { TS=(quasi-random* or quasi random* or pseudo-random* or pseudo random*) } \\
\text { Indexes=SCI-EXPANDED, SSCI, A\&HCI Timespan=2002-2018 }\end{array}$ \\
\hline 11 & $\begin{array}{l}\mathrm{TS}=\left(\left(\text { control or experiment }{ }^{*} \text { or conservative) NEAR/5 (treatment or therapy or procedure or man- }\right.\right. \\
\text { age })) \\
\text { Indexes }=\mathrm{SCI}-\mathrm{EXPANDED}, \mathrm{SSCl}, \mathrm{A} \& \mathrm{HCI} \text { Timespan=2002-2018 }\end{array}$ \\
\hline
\end{tabular}

\begin{tabular}{|c|c|}
\hline 12 & 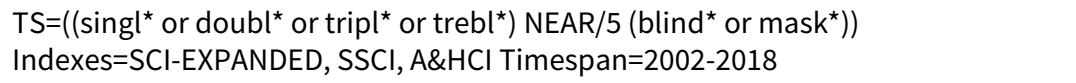 \\
\hline 13 & $\begin{array}{l}\text { TS=(cross-over or cross over or crossover) } \\
\text { Indexes=SCI-EXPANDED, SSCI, A\&HCI Timespan=2002-2018 }\end{array}$ \\
\hline 14 & $\begin{array}{l}\text { TS=(placebo* or sham) } \\
\text { Indexes=SCI-EXPANDED, SSCI, A\&HCI Timespan=2002-2018 }\end{array}$ \\
\hline 15 & $\begin{array}{l}\text { TS=trial } \\
\text { Indexes=SCI-EXPANDED, SSCI, A\&HCI Timespan=2002-2018 }\end{array}$ \\
\hline 16 & $\begin{array}{l}\left.\text { TS=(assign* or allocat }{ }^{\star}\right) \\
\text { Indexes=SCI-EXPANDED, SSCI, A\&HCI Timespan=2002-2018 }\end{array}$ \\
\hline 17 & $\begin{array}{l}\text { TS=controls } \\
\text { Indexes=SCI-EXPANDED, SSCI, A\&HCI Timespan=2002-2018 }\end{array}$ \\
\hline 18 & $\begin{array}{l}\# 17 \text { OR \#16 OR \#15 OR \#14 OR \#13 OR \#12 OR \#11 OR \#10 OR \#9 OR \#8 OR \#7 OR \#6 } \\
\text { Indexes=SCI-EXPANDED, SSCI, A\&HCI Timespan=2002-2018 }\end{array}$ \\
\hline 19 & $\begin{array}{l}\# 18 \text { AND \#5 AND \#4 } \\
\text { Indexes=SCI-EXPANDED, SSCI, A\&HCI Timespan=2002-2018 }\end{array}$ \\
\hline
\end{tabular}

\section{Search results: 345}

\section{Appendix 9. Other resources}

\section{Additional searches}

We searched the following conference abstracts and proceedings.

- European Stroke Conference (2011 to 2018)

- Stroke Society of Australasia Annual Scientific Meetings (2011 to 2017)

- World Stroke Congress (2000 to 2016)

- Asia Pacific Stroke Conference (2011 to 2017)

We also searched online clinical trials and research registers in May 2008.

- www.ClinicalTrials.gov (clinicaltrials.gov/) 
(emotion OR laughing OR cry OR weep OR tearful OR pseudobulbar affect ) AND Intracranial Hemorrhages OR Carotid Artery Diseases OR Brain Ischemia OR Cerebral Hemorrhage OR Cerebrovascular Disorders OR Stroke [DISEASE] = 153

- WHO International Clinical Trials Registry Platform (who.int/ictrp/search/en/)

Title: (stroke AND emotion OR stroke AND laughing OR stroke AND cry OR stroke AND weep OR stroke AND tearful OR stroke AND pseudobulbar affect) $=41$

ProQuest Dissertations and Theses Database was also searched on May $2018=364$

WHAT'S NEW

\begin{tabular}{lll}
\hline Date & Event & Description \\
\hline 22 October 2018 & $\begin{array}{l}\text { New citation required but conclusions } \\
\text { have not changed }\end{array}$ & Conclusions not changed \\
\hline 14 May 2018 & New search has been performed & $\begin{array}{l}\text { The searches and risk of bias tables have been updated and a } \\
\text { GRADE table added. We found no new trials for inclusion, so the } \\
\text { total number of included studies remains at seven, with 239 par- } \\
\text { ticipants. Two trials were of cross-over design and outcome da- } \\
\text { ta were not available from the first phase (precross-over) in an } \\
\text { appropriate format for inclusion as a parallel randomised con- } \\
\text { trolled trial (RCT). Thus, the results of the review were based on } \\
\text { five trials with 213 participants. One trial appears to meet the in- } \\
\text { clusion criteria for the review, but data are not available in a for- } \\
\text { mat suitable for including in the analyses (Kim 2017a). }\end{array}$
\end{tabular}

\section{H ISTORY}

Protocol first published: Issue 3, 2002

Review first published: Issue 2, 2004

\begin{tabular}{lll}
\hline Date & Event & Description \\
\hline 25 September 2009 & $\begin{array}{l}\text { New citation required but conclusions } \\
\text { have not changed }\end{array}$ & $\begin{array}{l}\text { The first author has changed and there is also a new author for } \\
\text { this version of the review. }\end{array}$ \\
\hline 20 August 2009 & New search has been performed & $\begin{array}{l}\text { This is a substantive amendment. The searches have been up- } \\
\text { dated. Two new trials have been added, making a total of seven } \\
\text { trials with 239 participants. Two trials appear to meet the review } \\
\text { inclusion criteria but information is not available in a format suit- } \\
\text { able for pooling. Three further trials have been excluded. }\end{array}$ \\
\hline
\end{tabular}

14 April $2008 \quad$ Amended Converted to new review format.

\section{CONTRIBUTIONS OF AUTHORS}

SA: contributed to writing the review. Completed title screening and inclusion/exclusion review, extracted any additional data needed and updated the risk of bias and 'Summary of findings' table KP: screened titles and abstracts for the current update

$\mathrm{AH}$ : contributed to writing the protocol and reviewed each version of this review

$\mathrm{MH}$ : contributed to writing the review. Completed title/abstract screening, extracted data and oversaw each version of this review 


\section{DECLARATIONS OF INTEREST}

SA: none known

KP: none known

$\mathrm{AH}$ : none known

$\mathrm{MH}$ : none known

\section{SOURCES OF SUPPORT}

\section{Internal sources}

- The George Institute for Global Health, Australia.

\section{External sources}

- Stroke Society of Australasia, Overseas Study Scholarship, Australia.

- Academic Unit of Psychiatry, University of Leeds, UK.

- Division of Clinical Neurosciences, University of Edinburgh, UK.

- Clinical Trials Research Unit, University of Auckland, New Zealand.

\section{DIFFERENCES BETWEEN PROTOCOL AND REVIEW}

There were methodological changes to the protocol and the review. We split the sensitivity analysis section into Subgroup analysis and investigation of heterogeneity and Sensitivity analysis.

For all dichotomous outcomes, we changed odds ratios (ORs) with 95\% confidence intervals (Cls) to risk ratios (RRs) with 95\% Cls (see Data and analyses).

\section{NDEX TERMS}

\section{Medical Subject Headings (MeSH)}

Affective Symptoms [ ${ }^{\star}$ drug therapy]; Antidepressive Agents [*therapeutic use]; Crying [* ${ }^{\star}$ psychology]; Laughter [ ${ }^{*}$ psychology]; Randomized Controlled Trials as Topic; Stroke [psychology]

\section{MeSH check words}

Humans 